\title{
Lerarenmobiliteit in Caribisch Nederland: achtergrond, verblijf en vertrek
}

Citation for published version (APA):

Cörvers, F., \& Mommers, A. (2016). Lerarenmobiliteit in Caribisch Nederland: achtergrond, verblijf en vertrek. ROA. ROA Technical Reports No. 006 https://doi.org/10.26481/umarot.2016006

Document status and date:

Published: 01/01/2016

DOI:

10.26481/umarot.2016006

Document Version:

Publisher's PDF, also known as Version of record

\section{Please check the document version of this publication:}

- A submitted manuscript is the version of the article upon submission and before peer-review. There can be important differences between the submitted version and the official published version of record.

People interested in the research are advised to contact the author for the final version of the publication, or visit the DOI to the publisher's website.

- The final author version and the galley proof are versions of the publication after peer review.

- The final published version features the final layout of the paper including the volume, issue and page numbers.

Link to publication

\footnotetext{
General rights rights.

- You may freely distribute the URL identifying the publication in the public portal. please follow below link for the End User Agreement:

www.umlib.nl/taverne-license

Take down policy

If you believe that this document breaches copyright please contact us at:

repository@maastrichtuniversity.nl

providing details and we will investigate your claim.
}

Copyright and moral rights for the publications made accessible in the public portal are retained by the authors and/or other copyright owners and it is a condition of accessing publications that users recognise and abide by the legal requirements associated with these

- Users may download and print one copy of any publication from the public portal for the purpose of private study or research.

- You may not further distribute the material or use it for any profit-making activity or commercial gain

If the publication is distributed under the terms of Article $25 \mathrm{fa}$ of the Dutch Copyright Act, indicated by the "Taverne" license above, 


\section{Lerarenmobiliteit in Caribisch Nederland: achtergrond, verblijf en vertrek}

Frank Cörvers

Ardi Mommers

\section{ROA Technical Report}

ROA-TR-2016/6

Researchcentrum voor Onderwijs en Arbeidsmarkt | ROA Research Centre for Education and the Labour Market | ROA 


\section{Lerarenmobiliteit in Caribisch Nederland: achtergrond, verblijf en vertrek}

Frank Cörvers

Ardi Mommers

ROA-TR-2016/6

September 2016

Research Centre for Education and the Labour Market Maastricht University

P.O. Box 616, 6200 MD Maastricht, The Netherlands

$\mathrm{T}+31433883647 \mathrm{~F}+31433884914$

secretary-roa-sbe@maastrichtuniversity.nl

www.roa.nl 


\section{Inhoud}

Pagina

Voorwoord 1

Samenvatting 2

1 Inleiding 5

1.1 Achtergrond 5

1.2 Voorstudies 5

1.3 Huidig onderzoek: doelstelling en onderzoeksaanpak 8

$\begin{array}{ll}1.4 \text { Opbouw rapportage en vervolg } & 10\end{array}$

2 Dataverzameling via enquête 11

2.1 Ontwikkeling van de vragenlijst 11

2.2 Contactgegevens 11

$\begin{array}{ll}2.3 \text { Procedure } & 12\end{array}$

$\begin{array}{ll}2.4 \text { Respons en representativiteit } & 13\end{array}$

$\begin{array}{ll}2.5 \text { Overige responsgegevens } & 15\end{array}$

$\begin{array}{ll}2.6 \text { Vooruitblik op verdere analyses } & 17\end{array}$

3 Migratieroutes en tevredenheid 18

3.1 Instroom van lesgevend personeel 18

3.1.1 Enkele migratieroutes van leraren zijn dominant 18

$\begin{array}{ll}3.1 .2 & \text { Immigratie vooral vanwege werk }\end{array}$

3.1.3 Caribisch leven belangrijke reden om te komen werken 21

3.2 Tevredenheid over informatie $\quad 22$

3.2.1 Caribische Nederlanders meer tevreden over informatie 23

3.2.2 Helft had meer informatie gewild over leef- en werkomstandigheden

3.2.3 Meer behoefte aan informatie over economische, culturele en onderwijs-context 26

3.3 Tevredenheid met baan en leven $\quad 28$

3.3.1 Baantevredenheid is laag ten opzichte van tevredenheid met leven 28

3.3.2 Europese Nederlanders minst tevreden met baan 29

4 Pull- en pushfactoren 31

4.1 Redenen om in baan te blijven ('pullfactoren') 31

4.1.1 Leven op het eiland, goede band met leerlingen en uitdagend werk meest genoemde redenen om in baan te blijven 31

4.1.2 Belangrijkste pullfactor vaak werkgerelateerd, specifieke redenen sterk variërend

4.2 Redenen om baan te verlaten ('pushfactoren') 36

4.2.1 Werkdruk en hoge kosten van levensonderhoud veelgenoemde redenen om baan te verlaten 
4.2.2 Belangrijkste pushfactor vooral werkgerelateerd, specifieke $\begin{array}{ll}\text { redenen sterk verschillend } & 40\end{array}$

$\begin{array}{ll}4.3 \text { Toekomstverwachtingen } & 42\end{array}$

4.3.1 Meer dan helft verwacht binnen vijf jaar huidige baan te verlaten 42

4.3.2 Drie kwart van Europese Nederlanders verwacht binnen vijf jaar huidige baan te verlaten

5 Nadere duiding van pull- en pushfactoren: kwalitatieve bevindingen

5.1 Werving: duidelijke informatie belangrijk, moeizame zoektocht naar geschikt personeel

5.2 Arbeidsvoorwaarden: veel tijdelijke contracten, salaris valt tegen

5.3 Eilandcultuur: professioneel klimaat en opvoeding in het gedrang

5.4 Schoolcultuur en HRM-beleid: hoge werkdruk, cultuurkloof, gebrekkige ondersteuning en nauwelijks talentbeleid

6 Conclusies en aanbevelingen 53

6.1 (Her)komst en voorbereiding 53

6.2 Pull- en pushfactoren bij huidige baan $\quad 55$

$\begin{array}{ll}\text { 6.2.1 Pullfactoren } & 55\end{array}$

$\begin{array}{lll}6.2 .2 & \text { Pushfactoren } & 55\end{array}$

$\begin{array}{ll}6.3 \text { Toekomstverwachtingen } & 57\end{array}$

6.4 Terugdringen hoge lerarenmobiliteit 58

$\begin{array}{ll}6.5 \text { Aanbevelingen } & 59\end{array}$

$\begin{array}{ll}\text { 6.5.1 Voorbereiding en voorlichting } & 60\end{array}$

$\begin{array}{ll}\text { 6.5.2 Motivatie } & 61\end{array}$

6.5.3 Arbeidsvoorwaarden en -omstandigheden en HRM-beleid 61

$\begin{array}{ll}6.6 \text { Tot slot } & 63\end{array}$

7 Referenties $\quad 65$

$\begin{array}{ll}\text { Bijlage A: Regressieanalyses } & 66\end{array}$

$\begin{array}{ll}\text { Bijlage B: Tabellenboek } & 72\end{array}$

Bijlage C: Vragenlijst 83

$\begin{array}{ll}\text { Bijlage D: Lijst van geïnterviewden } & 94\end{array}$ 


\section{Voorwoord}

Caribisch Nederland kent een grote dynamiek op de lerarenmarkt: de herkomst van de leraren is zeer divers en de uitstroom uit het lerarenberoep is hoog. Om een stabiele lerarenformatie op te bouwen is kennis nodig over de motieven om in de baan te blijven, dan wel de baan te verlaten ('pull- en pushfactoren'). Voorliggend empirisch onderzoek bouwt voort op een voorstudie naar de arbeidsmarktsituatie in Caribisch Nederland en een literatuurstudie naar het aantrekken en behouden van leraren in 'afgelegen gebieden'. De literatuur leert dat deze gebieden door hun specifieke karakter uitdagingen opleveren voor de werving en het behoud van personeel. In dit rapport wordt verslag gedaan van een onderzoek naar de relevante factoren bij werving en behoud van lesgevend personeel in Caribisch Nederland.

Het onderzoek combineert kwalitatieve inzichten uit interviews met sleutelfiguren ${ }^{1}$ met kwantitatieve inzichten uit een enquête onder lesgevend personeel in Caribisch Nederland. De enquête is ontwikkeld op basis van de opgedane kennis uit de literatuurstudie en de diverse interviews en behandelt de pull- en pushfactoren, de tevredenheid en de toekomstverwachtingen van het lesgevende personeel in Caribisch Nederland. Alle onderwijsinstellingen in het po, vo en mbo in Caribisch Nederland hebben hun medewerking verleend aan het onderzoek. De respons door het lesgevend personeel is met 43 procent hoog en geeft daarmee een sterke fundering voor de bevindingen.

Dit onderzoek is uitgevoerd door het Researchcentrum voor Onderwijs en Arbeidsmarkt $(\mathrm{ROA})$ in opdracht van Maestro Kompas. ${ }^{2}$ De auteurs danken Wim Didderen van Maestro Kompas voor het mogelijk maken van het onderzoek. Voorts danken zij de medewerkers van het Maestro Kompas team van de Open Universiteit voor hun commentaar op een eerdere versie van dit rapport. Maestro Kompas heeft een belangrijke bijdrage geleverd aan de sturing en de planning van het onderzoek. Dit geldt in het bijzonder voor Suzan Becks die op een zeer betrokken wijze en heel nauwgezet het werkbezoek heeft voorbereid, en tevens een groot aandeel had in de planning en begeleiding van alle onderzoek dat het ROA in opdracht van Maestro Kompas heeft uitgevoerd. Tevens willen we Marijke Schijns bedanken voor de uitstekende wijze waarop zij alle boekingen voor het strak geplande werkbezoek aan Caribisch Nederland heeft weten te realiseren.

Een speciaal woord dank is gericht aan de schoolleiders en medewerkers van alle deelnemende scholen, aan de docentcoaches en aan de overige contactpersonen op de eilanden (zie Bijlage D). Zonder hen was de uitvoering van dit onderzoek en het behalen van de hoge respons in de enquête onder lesgevend personeel niet mogelijk geweest. Dit geldt niet in de laatste plaats voor de onderwijsstaf van leraren en overige medewerkers die de moeite hebben genomen deel te nemen aan de interviews en enquêtes.

1. Waaronder leraren, schoolleiders, beleidsmakers en docentcoaches van Maestro Kompas

2. Programma voor Bonaire, Sint Eustatius en Saba dat tot doel heeft om samen met de regionale opleidingsinstituten te komen tot een regionale infrastructuur voor het opleiden van leraren. Zie verder www.maestrokompas.org. 


\section{Samenvatting}

\section{Bevindingen}

Veel scholen in Caribisch Nederland (h)erkennen het hoge verloop onder lesgevend personeel. Een hoog verloop betekent dat er elk jaar een team met veel nieuwe leraren moet worden samengesteld, wat niet gewenst is voor de zittende leraren, het management en de leerlingen. Dit komt vooral voor bij scholen waar veel Europese Nederlanders werken. Schoolleiders en HRM-medewerkers geven aan vaak moeite te hebben met een bevredigende invulling van de vacatures. Het komt te vaak voor dat het aantal geschikte kandidaten gering is, waardoor er weinig keuze is. Door het hoge verloop en de moeizame werving van geschikte kandidaten is de continuïteit van het onderwijs niet gewaarborgd en kan de onderwijskwaliteit in gevaar komen.

Een fors deel van het lesgevend personeel lijkt de komende jaren verloren te gaan voor het Caribisch Nederlandse onderwijs. Ruim de helft van de respondenten die een inschatting kunnen maken over de (nabije) toekomst, verwacht slechts maximaal vijf jaar de huidige functie te bekleden. Drie tiende (29\%) verwacht zelfs minder dan twee jaar in de huidige functie te blijven. Dit laatste cijfer over het verwachte kortetermijnverloop sluit redelijk goed aan bij het historisch berekende cijfer van bijna 15 procent gemddelde jaarlijkse uitstroom van lesgevend personeel (Cörvers, Claessen \& Kluijfhout, 2015).

De belangrijkste pushfactoren om het onderwijs te verlaten zijn werkgerelateerd, zoals een hoge werkdruk, onvoldoende salaris en matige mogelijkheden voor professionalisering. Op Sint Eustatius en Saba worden deze werkgerelateerde redenen echter minder vaak genoemd (61\%) dan op Bonaire (76\%). Op Sint Eustatius en Saba hebben de pushfactoren eerder te maken met de leefomstandigheden of het sociaal netwerk. De relatieve kleinschaligheid van Sint Eustatius en Saba ten opzichte van Bonaire lijkt hieraan ten grondslag te liggen. Zo wordt daar vaker genoemd dat de recreatiemogelijkheden en medische faciliteiten onvoldoende zijn, dat men is uitgekeken op het eiland, dat de sociale controle benauwend is of dat de partner er geen werk kan vinden.

De personeelsformatie in de onderwijssector in Caribisch Nederland is erg divers. Naast Caribische Nederlanders bestaat de ruime meerderheid van het lesgevende personeel uit immigranten, veelal van Europees Nederlandse komaf. Caribische Nederlanders die in het onderwijs les geven zijn vaak remigrant: zij zijn teruggekeerd naar hun eiland nadat ze buiten Caribisch Nederland een lerarenopleiding hebben gevolgd. ${ }^{3}$ Er zijn drie belangrijke verschillen tussen immigranten en Caribische Nederlanders (remigranten) wat betreft de beleving over het werken in het onderwijs in Caribisch Nederland.

3. Aangezien er geen structurele lerarenopleiding is in Caribisch Nederland, heeft een zeer groot deel van de Caribische Nederlanders tijdelijk elders gewoond, zie hoofdstuk 3. 
Ten eerste hebben de immigranten meer behoefte aan voorlichting bij de sollicitatieprocedure en zijn ze gemiddeld minder tevreden met hun baan dan Caribische Nederlanders. De omstandigheden op de eilanden - die sterk kunnen afwijken van wat men 'gewend' is - lijken hier een belangrijke rol in te spelen. Zo moeten immigranten vaak wennen aan de sociaal-culturele situatie op het eiland (omgang met autochtone inwoners en lokale gebruiken) en het pedagogischdidactisch klimaat op school (zoals de manier van les geven en omgang met leerlingen). Overigens geven ook veel remigranten aan dat ze meer informatie hadden willen ontvangen voorafgaand aan de start in hun baan.

Ten tweede verschillen immigranten en Caribische Nederlanders wat betreft de redenen om in hun huidige baan te blijven. Voor Caribische Nederlanders is de belangrijkste 'pullfactor' veel vaker werkgerelateerd (voor $84 \%$ van de respondenten) dan voor immigranten (60\%). Het gaat dan onder andere om het hebben van een goede band met de leerlingen, uitdagend werk of een vast dienstverband. Voor immigranten speelt juist het prettige eilandleven een belangrijke rol. Dat is niet verrassend aangezien zij ook vaak aangeven hiervoor naar het eiland te zijn gekomen.

Ten derde verschillen de toekomstverwachtingen over het werken in het onderwijs in Caribisch Nederland tussen immigranten en Caribische Nederlanders. Maar liefst drie kwart van de Europese Nederlanders verwacht binnen vijf jaar de huidige functie te verlaten, en ruim vier op de tien denkt zelfs binnen twee jaar vertrokken te zijn. Het betreft dan vaak het vertrek vanwege een functie buiten Caribisch Nederland. Daarentegen verwachten Caribische Nederlanders veel langer te blijven werken in hun huidige baan: slechts ruim een kwart maximaal vijf jaar en ruim zes op de tien $(62 \%)$ meer dan tien jaar, dan wel tot het pensioen.

\section{Aanbevelingen}

Eilanden zoals in Caribisch Nederland staan in de literatuur bekend als 'remote areas', waarvoor het vaak moeilijk is om geschikt hoger opgeleid personeel te vinden (De Hoon en Cörvers, 2016). Dit is de belangrijkste verklaring dat schoolleiders van onderwijsinstelingen in Caribisch Nederland moeite hebben om de vacatures op hun scholen naar tevredenheid in te vullen. Het terugdringen van de hoge lerarenmobiliteit in Caribisch Nederland is van belang om de wervings- en selectiekosten te drukken, maar vooral om de continuïteit van de onderwijskwaliteit te waarborgen. De onderstaande aanbevelingen kunnen hieraan bijdragen. Vanwege de geografische omstandigheden zal men echter in Caribisch Nederland altijd geconfronteerd blijven met een relatief grote migratiedynamiek en wervingsproblematiek voor onderwijspersoneel. Daardoor zijn de kosten voor het bereiken en instandhouden van een stabiele en kwalitatief goede lerarenpopulatie hoger dan in Europees Nederland.

De aanbevelingen zijn ruwweg in drie clusters onder te brengen, namelijk onder: a) betere voorbereiding en voorlichting, b) betere selectie op motivatie, en c) aantrekkelijkere werkomstandigheden en arbeidsvoorwaarden, inclusief betere 
professionele begeleiding. Dit laatste cluster valt uiteen in aanbevelingen die op schoolniveau en op bovenschools niveau dienen te worden gerealiseerd. De aanbevelingen komen voort uit de volgende vaststellingen. Ten eerste is gebleken dat vooral de Europese Nederlanders en in minder mate ook leraren van buiten Europees en Caribisch Nederland de voorlichting over de werkomstandigheden een onvoldoende geven. Ten tweede is gebleken dat veel Europese Nederlanders vooral voor het leven op het eiland, het avontuur en het klimaat naar Caribisch Nederland komen. Daardoor krijgen de ambities op professioneel vlak wellicht wat te weinig aandacht krijgen in de werving, selectie en begeleiding van nieuwe leraren. Ten derde wordt de werkdruk op Caribisch Nederland als hoog ervaren. Om te voorkomen dat leraren vertrekken is onder meer een betere professionalisering van leraren vereist, met meer uitdagingen, meer mogelijkheden voor scholing en formele en informele training, en een beter personeelsbeleid.

\section{Voorbereiding en voorlichting}

- Aanbeveling 1: Zorg in een zo vroeg mogelijk stadium voor een eerlijke, duidelijke voorlichting over het wonen en werken op het eiland.

- Aanbeveling 2: Probeer de poule van kandidaten die ervaring hebben in Caribisch Nederland groter te maken door regelmatig werkervarings- of stageplekken aan te bieden voor stagiaires, onderwijsassistenten en leraren-inopleidingen van andere (ei)landen.

- Aanbeveling 3: Tracht zoveel mogelijk samen te werken met andere scholen en overheden bij de voorlichting en de werving en selectie van kandidaten.

\section{Selectie op motivatie}

- Aanbeveling 4: Zet bij het aantrekken van nieuw personeel in op personeel dat zich wil committeren aan het eiland.

\section{Arbeidsvoorwaarden en HRM-beleid op schoolniveau}

- Aanbeveling 5: Communiceer duidelijk en tijdig de carrièremogelijkheden van elke leraar evenals de vereisten voor een vast contract.

- Aanbeveling 6: Heb oog voor personeel dat in de knel dreigt te komen door een hoge werkdruk.

- Aanbeveling 7: Investeer in goede onderwijsfaciliteiten op school.

- Aanbeveling 8: Faciliteer de professionele ontwikkeling.

\section{Arbeidsvoorwaarden en HRM-beleid op bovenschools niveau}

- Aanbeveling 9: Bied meer mogelijkheden voor doorstroom en carrièreperspectieven van leraren binnen en tussen onderwijsinstellingen in Caribisch Nederland.

- $\quad$ Aanbeveling 10: Bekijk of er op sommige punten tegemoet kan worden gekomen aan de hoge kosten van levensonderhoud.

- Aanbeveling 11: Creëer een structurele lerarenopleiding op Bonaire en/of maak afstandsonderwijs beter mogelijk. 


\section{$1 \quad$ Inleiding}

\subsection{Achtergrond}

Het ministerie van Onderwijs, Cultuur en Wetenschap (OCW) streeft naar een duurzame en bevoegde formatie van leraren in Caribisch Nederland - bestaande uit de eilanden Bonaire, Sint Eustatius en Saba (ook wel bekend als de 'BES-eilanden') ${ }^{4}$ - die bekwaam en betrokken is, vertrouwd is met lokale omstandigheden en cultuur, en die ook voor langere tijd werkzaam wil blijven in het onderwijs. Dit geldt zowel voor het primair onderwijs (po) als voor het voortgezet onderwijs (vo) en middelbaar beroepsonderwijs (mbo). De vraag is in welke mate op dit moment aan dat streven wordt voldaan. Zo blijkt dat een vijfde tot een kwart van de leraren niet bevoegd is of dat voor hen de bevoegdheid onbekend is (Cörvers, Claessen en Kluijfhout (2015). Bovendien is er een grote geografische mobiliteit op Bonaire, Sint Eustatius en Saba. Zowel van en naar Europees Nederland als van en naar andere (Caribische) landen. Dit weerspiegelt zich in de dynamiek op de lerarenmarkt. De herkomst van de leraren in Caribisch Nederland is zeer divers en de uitstroom uit het lerarenberoep (inclusief emigratie) is hoog. Dat resulteert in een hoge uitstroom van jaarlijks bijna 15 procent, en derhalve in een hoge vervangingsvraag.

De opbouw van een stabiel (en kwalitatief sterk) lerarenbestand vergt kennis over de motieven van leraren om in hun baan te blijven, dan wel om deze te willen verlaten. Maestro Kompas heeft het Researchcentrum voor Onderwijs en Arbeidsmarkt (ROA) verzocht onderzoek te verrichten naar factoren die het meer of minder aantrekkelijk maken om les te geven in Caribisch Nederland. Maestro Kompas is een programma voor Bonaire, Sint Eustatius en Saba dat tot doel heeft om samen met de regionale opleidingsinstituten te komen tot een regionale infrastructuur voor het opleiden van leraren in Caribisch Nederland. ${ }^{5}$

Alvorens we verder ingaan op het voorliggende onderzoek, bespreken we twee voorstudies die de (kennis)basis waren voor het huidige onderzoek.

\subsection{Voorstudies}

Voorliggend onderzoek naar de mobiliteit van leraren in Caribisch Nederland bouwt voort op twee voorstudies. In de eerste voorstudie van Cörvers, Claessen en Kluijfhout (2015) is nagegaan hoe de onderwijsarbeidsmarkt in Caribisch Nederland eruit ziet (ingezoomd op de lerarenpopulatie). Hierin zijn de diverse economische, sociale en culturele karakteristieken van de eilanden beschreven. Bovendien is nader ingegaan op het opzetten van een duurzame regionale onderwijsinfrastructuur

4. Bonaire, Sint Eustatius en Saba maken als 'openbare lichamen' (vgl. gemeenten) deel uit van Nederland. Dit in tegenstelling tot Curaçao, Aruba en Sint Maarten (de 'CAS-eilanden') die evenals (Europees) Nederland als onafhankelijke landen behoren tot het Koninkrijk der Nederlanden.

5. Het programma wordt door de Faculteit Educatie van de Hogeschool Utrecht en de Open Universiteit Nederland ontwikkeld in opdracht van het ministerie van Onderwijs, Cultuur en Wetenschap. 
gericht op het opleiden van voldoende gekwalificeerde leraren voor Caribisch Nederland. Er zijn immers geen zelfstandige lerarenopleidingen op de eilanden. Dat betekent dat leraren werkzaam in Caribisch Nederland meestal hun opleiding hebben genoten in Europees Nederland, op Curacao, Aruba of Sint Maarten (ook wel bekend als de 'CAS-eilanden') of elders in het Caribisch gebied. Er worden in dit vooronderzoek verschillende modellen beschreven voor het werven en/of opleiden van leraren (import, zelfvoorziening en bijscholing), en voor het opzetten van een digitale onderwijsinfrastructuur.

In de tweede voorstudie (De Hoon en Cörvers, 2016) is nader ingegaan op de problematiek van de lerarenmarkt in Caribisch Nederland aan de hand van een literatuuronderzoek. Het aantrekken en behouden van personeel blijkt voor werkgevers in afgelegen, dunbevolkte of rurale gebieden erg moeilijk. Lunn (1997) beschrijft bijvoorbeeld de barrières bij het behouden van leraren in landelijke en/of afgelegen gebieden. Ook levert de literatuurstudie 'good practices' om met deze uitdagingen om te gaan. Zo worden studenten in Australië middels speciale modules specifiek opgeleid in en bekend gemaakt met het lesgeven in afgelegen gebieden (Yarrow et al., 1999).

In het literatuuronderzoek is een aantal stromingen uit de economische en sociologische literatuur aangehaald die een theoretisch kader bieden voor migratiestromen. Deze theorieën geven verklaringen voor arbeidsmigratie aan de hand van zogenaamde 'pull- en pushfactoren'. Dit zijn factoren die het aantrekkelijk maken om een baan te betrekken en hierin te blijven ('pullfactoren) en factoren die juist het vertrek uit een baan stimuleren ('pushfactoren'). In de literatuurstudie zijn de factoren die een rol spelen bij migratiebeslissingen schematisch weergegeven. Tevens zijn de beleidsinstrumenten die relevant kunnen zijn om deze beslissingen te beïnvloeden hierin opgenomen. Een enigszins vereenvoudigd schematisch overzicht is opgenomen in Tabel 1.1.

In de neoklassieke economische theorie wordt ervan uitgegaan dat iemand migreert naar een land waar het verschil tussen verwachte opbrengsten en verwachte kosten zo hoog mogelijk is. Kosten en opbrengsten kunnen daarbij in brede zin worden opgevat. Onder kosten vallen dan investeringen als baanzoek- en verhuiskosten, maar ook immateriële kosten zoals het gemis aan familieleden en het opbouwen van een sociaal netwerk op de nieuwe plaats van bestemming. Hetzelfde geldt voor materiële en immateriële opbrengsten: zowel salaris als bijvoorbeeld professionaliteit en status van het beroep in het bestemmingsland ten opzichte van het herkomstland kunnen van belang zijn. We vatten deze theorie in het kader van ons onderzoek samen onder factoren die verwijzen naar de arbeidsvoorwaarden en omstandigheden.

In het zogeheten nieuw economisch model van arbeidsmigratie wordt de nadruk gelegd op de migratiebeslissing als collectieve beslissing van een huishouden. Dat wil zeggen, ook de afwegingen en de vooruitzichten van de partner (bijvoorbeeld werk en carrière) en de kinderen (schoolkeuze, kwaliteit onderwijs) zijn expliciet van belang. In het roltrapmodel wordt met name gekeken hoe migratie tussen regio's 
binnen een land kan worden verklaard. Hierbij is de invalshoek de levensfase van de potentiële migrant, waarbij de kenmerken van een regio pullfactoren zijn. Het gaat dan bijvoorbeeld om de mogelijkheden voor onderwijs en carrière in een roltrapregio en allerlei voorzieningen voor individu en familie in de betreffende levensfase. In het kader van ons onderzoek verwijzen de twee laatste theorieën naar het belang van de leefomstandigheden.

In de zogeheten netwerktheorie bepalen sociale netwerken van migranten in herkomst- en bestemmingslanden de migratiestromen. Een gemeenschap van migranten van dezelfde herkomst is voor de potentiële migrant van belang als informatiebron en als sociaal kapitaal. Ook de mate van sociale cohesie binnen de migrantengemeenschap alsmede een meer of minder geslaagde integratie in het bestemmingsland kunnen belangrijke factoren zijn voor potentiële nieuwe (arbeids)migranten. We vatten deze factoren samen onder de noemer sociaal netwerk.

Tabel 1.1 - Pull- en pushfactoren bij migratie en HRM-beleid

\begin{tabular}{|l|l|}
\hline $\begin{array}{l}\text { Pull- en pushfactoren van migratie tussen } \\
\text { landen en gebieden }\end{array}$ & $\begin{array}{l}\text { HRM-beleid gericht op } \\
\text { migratiebeslissingen }\end{array}$ \\
\hline $\begin{array}{l}\text { Economische theorie } \\
\begin{array}{l}\text { Arbeidsvoorwaarden: salaris, } \\
\text { contractduur, arbeidsduur }\end{array} \\
\begin{array}{l}\text { Status: economisch en sociaal (imago) } \\
\text { Huishoudsituatie: (werkende) partner, } \\
\text { (schoolgaande) kinderen }\end{array}\end{array}$ & $-\quad$ Financiële prikkels \\
$\begin{array}{l}\text { Roltraptheorie } \\
\text { Levensfase: studie, werk, } \\
\text { gezinsvorming }\end{array}$ & $-\quad$ Werving en selectie \\
$\begin{array}{l}\text { Sociologische theorie } \\
\text { Sociale cohesie en integratie: } \\
\text { aanwezigheid van dezelfde etnische } \\
\text { groepen, integratie in gemeenschap }\end{array}$ & $-\quad \begin{array}{l}\text { Professionaliseringsbeleid } \\
\text { Inductie- en mentorprogramma's } \\
\text { afgelegen gebieden) }\end{array}$ \\
\hline
\end{tabular}

Op basis van de voorstudie van De Hoon en Cörvers (2016) waarvan Tabel 1.1 is afgeleid, alsmede de ervaringen uit het werkbezoek en de interviews, kunnen we de pull- en pushfactoren derhalve indelen in drie typen.

- Arbeidsvoorwaarden en -omstandigheden: o.a. salaris, contractduur, carrièreperspectieven, werkdruk, HRM-beleid, professionalisering, omgang en samenwerking met collega's, ouders en leerlingen, imago van leraar.

- Leefomstandigheden: o.a. dagelijks leven, voorzieningen (onderwijs, medisch, cultureel), kosten van levensonderhoud, criminaliteit.

- Sociaal netwerk: o.a. integratie partner en kinderen, verbondenheid met eiland, sociale contacten.

Tot slot wordt in Tabel 1.1 op basis van de literatuurverkenning van De Hoon en Cörvers, (2016) een overzicht gegeven van de onderdelen van HRM-beleid die voor 
scholen van belang kunnen zijn. ${ }^{6}$ Bij het overwegen van extra financiële prikkels in de vorm van bijvoorbeeld loonsverhogingen voor nieuwe of zittende leraren, is het van belang duidelijkheid te hebben over wie men beoogd aan te trekken of te behouden. Financiële prikkels moeten onderdeel uitmaken van de werving en selectie, het arbeidsvoorwaardenpakket, en het HRM-beleid als geheel. Daarvoor is vaak maatwerk nodig. Naast aandacht voor financiële prikkels, is bij de aanstelling en het behoud van leraren aandacht nodig voor de ontwikkelingen van hun vakkennis en pedagogisch-didactische vaardigheden, de motivatie en toewijding van de leraar (in opleiding), het bezit van culturele sensitiviteit, het vermogen om te overtuigen en beïnvloeden, en het vermogen om relaties op te bouwen. Dit vraagt om een breed professionaliseringsbeleid van scholen voor hun lesgevende personeel.

Actieve werving van leraren in 'remote areas' kan het beste worden gericht op leraren die zelf afkomstig zijn uit landelijke gebieden, en daar dus ervaring mee hebben. Vooroordelen over lesgeven in afgelegen, landelijke gebieden, kunnen worden weggenomen door leraren in opleiding kennis te laten maken met het lesgeven aldaar. Kennis en begrip omtrent rurale scholen en samenlevingen blijkt zich positief te ontwikkelen als gevolg van praktijkervaring tijdens de opleiding. Bovendien kan op deze manier vroegtijdig de selectie van de beste en/of meest geschikte leraren plaatsvinden, wat de kwaliteit en status van de leraren ten goede zal komen. Daarnaast kan worden gedacht aan andere manieren voor de verdere professionalisering van het onderwijs. Een voorbeeld hiervan is het vergroten van de professionele ruimte die leraren van schoolleiders krijgen om zich te ontwikkelen. Andere instrumenten om de kwaliteit van leraren te verhogen zijn inductie- en mentorprogramma's, met als doel de slaagkansen van beginnende leraren te vergroten en de kans op voortijdige uittrede te verkleinen. Deze programma's blijken zowel op professioneel gebied als in de privésfeer (integratie in de sociale context) positieve effecten te kunnen voortbrengen.

\subsection{Huidig onderzoek: doelstelling en onderzoeksaanpak}

Hoewel de hiervoor besproken voorstudies veel inzicht hebben verschaft in de onderwijscontext in Caribisch Nederland en in de theoretische motieven voor komst en vertrek, leveren ze nog geen kennis op over wat het les geven in Caribisch Nederland meer of minder aantrekkelijk maakt. Vanuit het streven van het ministerie van OCW naar een duurzame lerarenformatie is het belangrijk om meer inzicht en verdieping te krijgen in de specifieke factoren die ertoe leiden dat leraren in het Caribisch Nederlandse onderwijs willen komen of blijven werken ('pullfactoren'), dan wel hun baan geven willen opgeven ('pushfactoren'). Wat maakt les geven in Caribisch Nederland aantrekkelijk, wat minder aantrekkelijk en hoe kan dit laatste verbeterd worden?

Deze onderzoeksrapportage gaat in op deze factoren en vragen. De benodigde kennis is verzameld door middel van interviews met sleutelinformanten en

6. De laatste twee alinea's van deze paragraaf zijn deels letterlijk overgenomen uit de samenvatting in De Hoon en Cörvers (2016).

8 
enquêtering onder lesgevend personeel in Caribisch Nederland. Aan de hand van de onderzoeksbevindingen worden aanbevelingen geformuleerd om het aanbod van (hoogwaardige) leraren voor de toekomst zoveel mogelijk te kunnen garanderen, zowel wat betreft kwantiteit als kwaliteit. Daarbij is er aandacht voor de werving van leraren uit het Caribisch gebied, uit Europees Nederland en elders, maar ook voor het behoud van goede leraren die al werkzaam zijn in Caribisch Nederland.

Het onderzoek is in twee fasen tot stand gekomen: een kwalitatieve en een kwantitatieve fase. De kwalitatieve fase bestaat uit verdiepende interviews met sleutelinformanten, grotendeels afgenomen tijdens een werkbezoek aan scholen in Caribisch Nederland. Bij de organisatie van de gesprekken is dankbaar gebruik gemaakt van het netwerk en de bemiddelende inspanningen van het Maestro Kompas team. In deze kwalitatieve fase is afgetast welke factoren een rol kunnen spelen bij de keuze voor een baan in het Caribisch Nederlandse onderwijs en welke uitdagingen er op HRM-gebied worden ervaren door schoolleiders en beleidsmakers. Voorafgaand aan het werkbezoek ontvingen scholen in Caribisch Nederland een aankondigingsbrief met daarin het doel en de aanpak van het onderzoek. De interviews zijn gehouden met:

- Docenten over hun motieven om te werken in het onderwijs in Caribisch Nederland, en over hun tevredenheid met de werk- en leefomgeving;

- Schoolleiders en stafmedewerkers van onderwijsinstellingen in het po, vo en mbo, alsmede docentcoaches van Maestro Kompas over de onderwijscontext en de problematiek rondom het HRM-beleid in Caribisch Nederland;

- Beleidsmakers (o.a. van ministeries) van Europees en Caribisch Nederland over de geldende arbeidsvoorwaarden en regelingen voor leraren in Caribisch Nederland, en de mogelijkheden voor het opzetten van een onderwijsinfrastructuur voor leraren in het Caribisch gebied.

De tweede onderzoeksfase is kwantitatief van aard en bestaat uit een verdiepende enquête (digitaal, via internet) onder de hele populatie van lesgevend personeel (leraren en andere lesgevende functies) in het po, vo en mbo van Caribisch Nederland (ruim 450 personen). Onderwerpen die aandacht hebben gekregen in de enquête zijn:

- Achtergrond- en baankenmerken zoals leeftijd, geslacht, gezinssamenstelling;

- (Re)migratiemotieven;

- Voorlichting bij de werving;

- Tevredenheid (voorlichting, baan, leven);

- Redenen om in baan te blijven (pullfactoren);

- Redenen om baan te verlaten (pushfactoren);

- Toekomstverwachtingen. 


\subsection{Opbouw rapportage en vervolg}

Voorliggende rapportage is voor een belangrijk deel gebaseerd op de enquête onder lesgevend personeel. Hoofdstuk 2 geeft daarom een uitgebreide beschrijving van de totstandkoming van de vragenlijst, alsmede van de dataverzamelingsprocedure en de responsgegevens. In hoofdstukken 3 en 4 worden de belangrijkste bevindingen uit de enquête gepresenteerd aan de hand van figuren en tabellen. Hoofdstuk 3 gaat nader in op de migratieroutes van onderwijspersoneel en de tevredenheid met hun baan en leven. Hoofdstuk 4 behandelt de pull- en pushfactoren en de toekomstverwachtingen. In hoofdstuk 5 worden de interviews met de sleutelfiguren besproken ter aanvulling op en verdieping bij de enquêtebevindingen. Tot slot komen in hoofdstuk 6 de conclusies en aanbevelingen aan bod.

Het kan wenselijk zijn om in een latere fase ook leerlingen in Caribisch Nederland te bevragen en/of onderzoek te verrichten onder (toekomstig) lesgevend personeel uit Curaçao, Aruba en Sint Maarten. Hiermee kan bijvoorbeeld kennis opgedaan worden over de (on)aantrekkelijkheid van mobiliteit binnen het Caribisch gebied. Ook zou het interessant zijn om meer inzicht te verkrijgen in de vertrekmotieven van (ex-)leraren die het Caribisch Nederlandse onderwijs in de afgelopen jaren hebben verlaten. 


\section{Dataverzameling via enquête}

In dit hoofdstuk wordt de totstandkoming van de enquête onder lesgevend personeel in Caribisch Nederland behandeld. We bespreken de wijze waarop de vragenlijst is geconstrueerd en de procedure van de dataverzameling. Tevens komen de responspercentages en de representativiteit van de respons aan de orde, en presenteren we enkele achtergrondgegevens van de responsgroep.

\subsection{Ontwikkeling van de vragenlijst}

De gegevens voor dit onderzoek zijn verzameld via een online vragenlijst onder lesgevend personeel (leraren en andere lesgevende functies ${ }^{7}$ ) in Caribisch Nederland. De inhoud van de vragenlijst (zie Bijlage C: Vragenlijst) is tot stand gekomen op basis van inzichten uit de twee voorstudies (met name de literatuurstudie van De Hoon en Cörvers, 2016) en de kwalitatieve onderzoeksfase. De voorstudie heeft kennis opgeleverd vanuit verschillende wetenschappelijke disciplines over factoren die van belang zijn bij komst, verblijf en vertrek van leraren. Deels betreffen dat factoren die in algemene zin relevant kunnen zijn voor keuzes rondom banen (zoals het dienstverband of het salaris), deels betreffen het factoren die specifiek van belang kunnen zijn in afgelegen gebieden (zoals de voorzieningen of sociale contacten). De kwalitatieve onderzoeksfase bestond uit interviews met een groot aantal sleutelfiguren (zie Bijlage D: Lijst van geïnterviewden). Deze gesprekken gingen onder andere over de specifieke omstandigheden die lesgeven op de eilanden meer of minder aantrekkelijk maken, en de uitdagingen die scholen bij onder meer de werving van personeel ervaren. De gesprekken zijngehouden met groepen leraren, docentcoaches van Maestro Kompas, schoolleiders, stafmedewerkers en beleidsmakers.

$\mathrm{Na}$ afloop van de kwalitatieve onderzoeksfase (interviews) is de inhoud van de vragenlijst in voorlopige, 'papieren vorm' (Word-bestand) vastgesteld en tweetalig ontworpen (Nederlands en Engels). De vragenlijst is voorafgaand aan de daadwerkelijke, digitale dataverzameling verspreid onder de contactpersonen van de scholen (meestal de schoolleiders) op de eilanden. Hiermee werd het onderzoek nogmaals onder de aandacht gebracht van de scholen. Vervolgens is de vragenlijst digitaal geprogrammeerd en getest bij een aantal proefpersonen.

\subsection{Contactgegevens}

Om de online vragenlijst te kunnen versturen naar het lesgevend personeel in Caribisch Nederland, zijn de schoolleiders/contactpersonen van de onderwijsinstellingen op de drie eilanden verzocht om contactgegevens van hun werknemers aan te leveren. Er was een grote welwillendheid van de scholen om vertegenwoordigd te zijn in het onderzoek. Alle scholen in het po, vo en mbo hebben

7. Het gaat hierbij zowel om volledig lesgevende functies, zoals onderwijsassistenten, alsook om andere functies waarbij een deel van de tijd les wordt gegeven (bijvoorbeeld schoolleiders met lesgevende taken). 
gereageerd op ons verzoek. Aangezien de contactgegevens door de besturen/scholen zijn aangeleverd, is bekend op welk eiland en in welke onderwijssector de personen in de aanschrijvingsbestanden werkzaam zijn. Lesgevend personeel dat werkzaam isin het $\mathrm{po}^{8}$ vormt 45 procent van het aanschrijvingsbestand en lesgevend personeel dat werkzaam is in het vo/mbo 55 procent.

In de aanschrijvingsbestanden komt het voor dat personen op meerdere scholen of vestigingen binnen hetzelfde bestuur werkzaam zijn. Er zijn in de bestanden echter geen personen geïdentificeerd die bij verschillende besturen, laat staan op verschillende eilanden, werkzaam zijn. Alle personen in het aanschrijvingsbestand zijn derhalve unieke personen.

\subsection{Procedure}

De oproep voor deelname aan de enquête is op 6 juni 2016 per e-mail verzonden aan 456 personen. In de uitnodigingsmail werd het doel van het onderzoek gecommuniceerd en trof men een gepersonaliseerde link naar de online vragenlijst. Deze digitale vragenlijst is tweetalig aangeboden, waarbij de 'standaardtaal' voor personen uit Bonaire op het Nederlands was ingesteld en voor personen uit Sint Eustatius en Saba op het Engels. Deelnemers konden in de vragenlijst naar eigen voorkeur wisselen tussen de talen.

Om de responsbereidheid te vergroten, is tijdens de dataverzamelingsperiode besloten om een tablet (iPad) te verloten onder de deelnemers. Ook is tijdens de dataverzameling contact geweest met de schoolleiders, opdat zij het onderzoek intern nogmaals onder de aandacht konden brengen. Tot slot is op zowel de website van Maestro Kompas als op de gezamenlijke Facebook-pagina van leraren van Caribisch Nederland een bericht geplaatst met een oproep tot deelname.

Op 16 juni 2016 is per e-mail een herinnering verstuurd aan de uitgenodigden die nog niet aan de vragenlijst waren begonnen of deze nog niet hadden afgerond. Hierin werd melding gemaakt van de verloting van de tablet. Op 23 juni is een tweede en laatste herinnering verstuurd, eveneens met vermelding van de loterij. Op maandag 27 juni is de enquête definitief afgesloten, en is willekeurig een prijswinnaar getrokken onder de deelnemers.

Tijdens het openstaan van de online vragenlijst, zijn per e-mail vijf ingevulde 'papieren' vragenlijsten binnengekomen bij de onderzoekers. Deze vragenlijsten waren afkomstig van leraren van een instelling voor volwassenonderwijs die geen adresgegevens van lesgevend personeel had aangeleverd. Deze 'papieren' vragenlijsten zijn handmatig verwerkt en opgenomen in het onderzoeksbestand. Voor het gemak gaan we vanwege deze vijf 'extra' vragenlijsten uit van een

8. Personen die zowel in het po, als in het vo/mbo te werken (bijvoorbeeld werkzaam bij expertisecentra), worden hier tot 'po' gerekend. 
aanschrijvingspopulatie van 461 personen (456 personen vanuit de contactgegevensbestanden plus vijf extra aanmeldingen).

\section{$2.4 \quad$ Respons en representativiteit}

De respons op het moment van sluiting van de enquête kan als (zeer) goed worden beschouwd. Afhankelijk van de afbakening van het begrip 'respons' ligt het percentage tussen de 44 procent (op basis van deelnemers die de vragenlijst ten minste gedeeltelijk hebben ingevuld) en 41 procent (op basis van deelnemers die de gehele vragenlijst hebben afgerond). In absolute termen gaat het om respectievelijk 204 en 187 respondenten. Op alle scholen/besturen in het po, vo en mbo is er sprake geweest van deelname door meerdere personen.

In Tabel 2.1 is de responsverdeling naar eiland en onderwijssector te zien. De responspercentages verschillen weliswaar tussen de groepen, vooral tussen po en vo op Saba, maar wijken niet statistisch significant af van elkaar (onder andere door de kleine aantallen). De respons kan om deze reden als representatief naar eiland en sector beschouwd worden. In de analyse zal daarom niet gewogen worden. ${ }^{9}$ Omdat er in het aanschrijvingsbestand in de meeste gevallen geen informatie over het type functie bekend was, kunnen we geen uitspraken doen over eventuele responsverschillen naar functie. Deze informatie is pas in de vragenlijst zelf verkregen. $^{10}$

Een zeer klein deel van de respondenten $(<1 \%)$ bleek niet tot de eigenlijke doelgroep van het onderzoek te behoren of beëindigde de vragenlijst al tijdens de selectievragen. ${ }^{11}$ Het netto aantal personen dat maximaal 'analyseerbaar' is (dat wil zeggen ten minste een deel van de vragenlijst ingevuld), oftewel de 'responsgroep' betreft derhalve 197 personen, ofwel 43 procent van de aanvankelijk benaderde populatie.

9. 'Weging' betreft de methodiek om voor over- of ondervertegenwoordiging van bepaalde responsgroepen te corrigeren.

10. Aangezien in de analyse altijd gekeken wordt naar eventuele verschillen in antwoordpatronen tussen functies, zijn mogelijke responsverschillen naar functie niet problematisch.

11. Alvorens inhoudelijke vragen gesteld werden, werden de respondenten enkele screeningsvragen gesteld. Respondenten die niet in het onderwijs in Caribisch Nederland werkzaam zijn en/of geen lesgevende functie uitoefenen, konden de vragenlijst niet voortzetten. 
Tabel 2.1 - Responsoverzicht naar eiland en onderwijssector

\begin{tabular}{|c|c|c|c|c|c|c|}
\hline & \multirow{2}{*}{$\begin{array}{c}\text { Aangeschreven } \\
\text { Aantal }\end{array}$} & \multicolumn{2}{|c|}{ Vragenlijst gestart } & \multicolumn{2}{|c|}{ Responsgroep } \\
\hline & & & Aantal & Percentage & Aantal & Percentage \\
\hline \multirow[t]{2}{*}{ Bonaire } & po & 166 & 66 & $40 \%$ & 64 & $39 \%$ \\
\hline & $\mathrm{vo} / \mathrm{mbo}$ & 198 & 93 & $47 \%$ & 89 & $45 \%$ \\
\hline \multirow{2}{*}{$\begin{array}{l}\text { Sint } \\
\text { Eustatius }\end{array}$} & po & 27 & 14 & $52 \%$ & 14 & $52 \%$ \\
\hline & $\mathrm{vo} / \mathrm{mbo}$ & 32 & 15 & $47 \%$ & 14 & $44 \%$ \\
\hline \multirow[t]{2}{*}{ Saba } & po & 14 & 9 & $64 \%$ & 9 & $64 \%$ \\
\hline & $\mathrm{vo} / \mathrm{mbo}$ & 24 & 7 & $29 \%$ & 7 & $29 \%$ \\
\hline Totaal & & 461 & 204 & $44 \%$ & 197 & $43 \%$ \\
\hline
\end{tabular}

Bron: Enquête lerarenmobiliteit Caribisch Nederland, ROA (2016)

In Tabel 2.2 en Tabel 2.3 zien we enkele specificaties van de 197 personen die in de analyses zijn meegenomen. Uit Tabel 2.2 volgt dat acht op de tien respondenten $(78 \%)$ werkzaam is op Bonaire en de overige respondenten op Sint Eustatius (14\%) en Saba (8\%).

Tabel 2.2 - Respondenten naar eiland $(n=197)$

\begin{tabular}{lcc}
\hline & Aantal & Percentage \\
\hline Eiland & 153 & \\
Bonaire & 28 & $78 \%$ \\
Sint Eustatius & 16 & $14 \%$ \\
Saba & 197 & $8 \%$ \\
\hline Totaal & $100 \%$ \\
\hline Bron: Enquête lerarenmobiliteit Caribisch Nederland, ROA (2016)
\end{tabular}

Tabel 2.3 laat zien dat drie kwart van de respondenten $(75 \%)$ leraar is, zowel op Bonaire als op Sint Eustatius en Saba. Leraren in opleiding en (technisch) onderwijsassistenten maken beide 5 procent uit van de totale respons. De overige lesgevende functies betreffen onder meer schoolleiders, teamleiders, intern begeleiders en instructeurs. De verdeling tussen po enerzijds en vo/mbo anderzijds ligt niet ver uit elkaar: respectievelijk 44 en 56 procent. Op Bonaire betreft het vaker respondenten uit het vo/mbo, op Sint Eustatius en Saba zijn er iets meer respondenten uit het po.

Bijna de helft van de respondenten komt oorspronkelijk uit Europees Nederland, zowel op Bonaire (42\%) als op Sint Eustatius en Saba (48\%). Kijken we naar de overige herkomstlanden, dan verschilt dit sterk tussen Bonaire enerzijds en Sint Eustatius en Saba anderzijds. Van de respondenten die op Bonaire werken, is 24 procent op Bonaire geboren, 15 procent is geboren op Curaçao en de resterende 18 procent elders. Van de respondenten werkzaam op Sint Eustatius en Saba is 11 procent op Sint Eustatius geboren, 9 procent op Saba en 32 procent buiten Caribisch of Europees Nederland. 
Tabel 2.3 - Achtergrondkenmerken analysepopulatie, naar eiland ${ }^{12}(n=197)$

\begin{tabular}{|c|c|c|c|c|c|c|}
\hline & \multicolumn{2}{|c|}{ Bonaire } & \multicolumn{2}{|c|}{ Sint Eustatius en Saba } & \multicolumn{2}{|c|}{ Totaal } \\
\hline & Aantal & $\%$ & Aantal & $\%$ & Aantal & $\%$ \\
\hline \multicolumn{7}{|l|}{ Functie } \\
\hline Leraar & 114 & $75 \%$ & 33 & $75 \%$ & 147 & $75 \%$ \\
\hline Leraar in opleiding & 8 & $5 \%$ & 2 & $5 \%$ & 10 & $5 \%$ \\
\hline $\begin{array}{l}\text { Onderwijsassistent / } \\
\text { TOA }\end{array}$ & 10 & $7 \%$ & 0 & $0 \%$ & 10 & $5 \%$ \\
\hline Anders, namelijk & 21 & $13 \%$ & 9 & $20 \%$ & 30 & $15 \%$ \\
\hline Totaal & 153 & $100 \%$ & 44 & $100 \%$ & 197 & $100 \%$ \\
\hline \multicolumn{7}{|l|}{ Sector } \\
\hline po & 64 & $42 \%$ & 23 & $52 \%$ & 87 & $44 \%$ \\
\hline $\mathrm{vo} / \mathrm{mbo}$ & 89 & $58 \%$ & 21 & $48 \%$ & 110 & $56 \%$ \\
\hline Totaal & 153 & $100 \%$ & 44 & $100 \%$ & 197 & $100 \%$ \\
\hline $\begin{array}{l}\text { Geboorte(ei)land } \\
\text { Europees Nederland }\end{array}$ & 65 & $42 \%$ & 21 & $48 \%$ & 86 & $44 \%$ \\
\hline Bonaire & 37 & $24 \%$ & 0 & $0 \%$ & 37 & $19 \%$ \\
\hline Sint Eustatius & 0 & $0 \%$ & 5 & $11 \%$ & 5 & $3 \%$ \\
\hline Saba & 0 & $0 \%$ & 4 & $9 \%$ & 4 & $2 \%$ \\
\hline Curaçao & 23 & $15 \%$ & 1 & $2 \%$ & 24 & $12 \%$ \\
\hline Suriname & 14 & $9 \%$ & 2 & $5 \%$ & 16 & $8 \%$ \\
\hline Elders & 13 & $8 \%$ & 10 & $23 \%$ & 23 & $12 \%$ \\
\hline Geen antwoord & 1 & $1 \%$ & 1 & $2 \%$ & 2 & $1 \%$ \\
\hline Totaal & 153 & $100 \%$ & 44 & $100 \%$ & 197 & $100 \%$ \\
\hline
\end{tabular}

Bron: Enquête lerarenmobiliteit Caribisch Nederland, ROA (2016)

\subsection{Overige responsgegevens}

In de eerste 15 tabellen van Bijlage B: Tabellenboek, wordt de responsgroep naar nog een aantal andere kenmerken (dan die reeds vermeld zijn in Tabel 2.3) onderverdeeld. Deze kenmerken worden in de volgende twee analysehoofdstukken niet nader uitgelicht om de (reeds vele) onderzoeksbevindingen zo overzichtelijk en leesbaar mogelijk te houden. Het betreft hier de onderverdeling naar geslacht, leeftijd, gezinssamenstelling, het aantal werkzame jaren in de huidige functie, in de onderwijssector en op het eiland, en de duur van het arbeidscontract. Al deze kenmerken kunnen een rol spelen bij de mobiliteit van leraren, vandaar dat ze hieronder kort worden besproken.

Ruim driekwart van het lesgevend personeel is vrouw. Zij zijn vooral vertegenwoordigd in het primair onderwijs: 89 procent is daar van het vrouwelijk geslacht tegenover 67 procent in het voortgezet en middelbaar beroepsonderwijs. Bijna een vijfde van het lesgevende personeel is jonger dan 30 jaar. Meer dan de helft is 40 jaar of ouder. Opvallend is dat bijna de helft van het lesgevende personeel geen thuiswonende kinderen heeft. Van belang voor de mobiliteit van personeel is wellicht ook dat 60 procent samenwoont met een partner, hoewel dit zowel een versterkend als verzwakkend effect kan hebben op de intentie om te willen blijven in de baan en/of op het eiland. Door commitment aan de partner kan het zijn dat men

12. Vanwege kleine aantallen voor Sint Eustatius en Saba zijn de cijfers van deze eilanden bij elkaar opgeteld. 
eerder geneigd is te vertrekken als de partner niet wil blijven, andersom kan het natuurlijk ook zijn dat men juist eerder geneigd is om te blijven juist omdat de partner wil blijven.

De mobiliteit van het lesgevend personeel blijkt groot te zijn. De helft is korter dan vijf jaar in de huidige functie werkzaam, waarbij dit aandeel voor personen boven de 40 jaar weliswaar lager ligt, maar met 40 procent alsnog relatief hoog is. Bij personen onder de 40 jaar betreft het 66 procent. Eveneens de helft van de respondenten is korter dan vijf jaar werkzaam op het eiland waar men woont, wel zijn de verschillen naar leeftijd hier iets groter. Een derde van de personen boven de 40 jaar is korter dan vijf jaar werkzaam op het eiland, tegen bijna zeven tiende van de personen onder de 40 jaar.

Toch is maar liefst 60 procent tien jaar of langer werkzaam in het onderwijs (84\% onder personen van 40 jaar of ouder en $34 \%$ onder personen onder de 40 jaar). Wanneer we personen die momenteel in hun eerste baan werken buiten beschouwing laten, dan blijkt dat drie kwart van de respondenten in de vorige baan reeds binnen de onderwijssector werkte (geen verschillen naar leeftijden), en meer dan de helft (52\%) werkte in de vorige baan in Europees Nederland. Deze cijfers duiden op een relatief grote baanmobiliteit en geografische mobiliteit in het verleden, ten opzichte van een lage sectormobiliteit. Een fors deel van het lesgevend personeel in Caribisch Nederland is immers pas sinds enkele jaren werkzaam in de huidige functie en op het huidige eiland, terwijl het vaak wel personen betreft die al (langere tijd) in het onderwijs werken.

Ondanks dat vrij veel personen relatief kort in de functie werken, heeft maar liefst 87 procent een vast dienstverband of uitzicht daarop (personen onder de 40 jaar zitten daarbij wel vaker nog in de tijdelijke fase). Opvallend is verder dat bijna iedereen aangeeft voltijds te werken (94\%), in tegenstelling tot de situatie in Europees Nederland. In het po, vo en mbo van Europees Nederland werkt (in 2015) respectievelijk 44, 64 en 63 procent van de personen voltijds. ${ }^{13}$

Ruim de helft (56\%) van alle docenten heeft de lerarenopleiding in Europees Nederland gevolgd. Het percentage dat in Europees Nederland is geboren of opgegroeid (met 16 jaar aldaar woonachtig) is lager, respectievelijk 44 en 51 procent. Degenen die op Bonaire, Sint Eustatius of Saba zijn opgegroeid gaan vaak naar Europees Nederland of een ander eiland in het Caribisch gebied om daar een lerarenopleiding te volgen. Opvallend is dat toch nog 10 procent een lerarenopleiding op Bonaire heeft gevolgd. Op Bonaire wordt er slechts een lerarenopleiding van de Universiteit van Curaçao (LOFO, i.e. Lerarenopleiding Funderend Onderwijs) aangeboden, en deze start alleen bijvoldoende aanmeldingen. In relatie tot de mobiliteit is het nog van belang op te merken dat bijna alle respondenten aangeven

13. De vergelijking tussen Caribisch Nederland (op basis van de vragenlijst) en Europees Nederland (op basis van de Open Onderwijsdata van DUO) is hier indicatief. De cijfers zijn niet één op één te vergelijken. In de vragenlijst onder lesgevend personeel in Caribisch Nederland is gevraagd of men 'voltijd' of 'deeltijd' werkt. Het betreft hier dus een eigen 'inschatting', terwijl de DUO cijfers gebaseerd zijn op het aandeel personen in de sector dat in 2015 meer dan 0,8 fte werkzaam was. 
de Nederlandse of Engelse taal te beheersen, en bijna twee derde aangeeft het Papiamento te beheersen.

\section{$2.6 \quad$ Vooruitblik op verdere analyses}

In de volgende twee hoofdstukken wordt de aandacht gericht op immigratie, voorlichting, tevredenheid en de pull- en pushfactoren. Er wordt getoetst of er sprake is van verschillen naar eiland van schoollocatie, naar onderwijssector, naar functie en naar geboorte(ei)land. Daar waar de verschillen (statistisch) significant zijn, zullen deze specificaties grafisch dan wel tekstueel behandeld worden. Aangezien de aantallen voor diverse groepen beperkt zijn, hanteren we bij deze specificaties de volgende, ruwere indelingen:

- $\quad$ eiland: verschillen tussen 'Bonaire' en 'Sint Eustatius / Saba' (ofwel 'benedenwinds' en 'bovenwinds')

- $\quad$ sector: verschillen tussen 'po' en 'vo / mbo'

- functie: verschillen tussen 'leraren' en 'andere (lesgevende) functies'14

- geboorte(ei)land: verschillen tussen '(Europees) Nederland', 'Bonaire, Sint Eustatius en Saba' en 'overige (ei)landen'.

Bij deze specificaties naar achtergrondkenmerken gaat het om zogenaamde 'bivariate' verbanden, dat wil zeggen zonder gelijktijdig rekening te houden met overige variabelen. Om meer verdieping te kunnen bieden, zijn tevens regressieanalyses ${ }^{15}$ uitgevoerd. Deze analyses kunnen helpen om te achterhalen welke kenmerken vooral 'verantwoordelijk' zijn voor de verschillen. Dit is zinvol, omdat verschillende kenmerken onderling (kunnen) samenhangen.

14. Te weten: leraren in opleiding, onderwijsassistenten, instructeurs, schoolleiders, teamleiders, intern begeleiders en andere lesgevende functies.

15. In deze regressieanalyses zijn bovendien opgenomen: geslacht en leeftijd (dichotoom: 'jonger dan 40 jaar of ' 40 jaar of ouder'). 


\section{$3 \quad$ Migratieroutes en tevredenheid}

In dit hoofdstuk wordt de instroom van lesgevend personeel in het Caribisch Nederlandse onderwijs besproken. Aan de orde komen de migratieroutes van het lesgevende personeel, de motieven om bij een onderwijsinstelling in Caribisch Nederland aan het werk te gaan, de tevredenheid met de informatie rondom deze beslissing, en de tevredenheid over de baan in het onderwijs en het leven in Caribisch Nederland.

\subsection{Instroom van lesgevend personeel}

\subsubsection{Enkele migratieroutes van leraren zijn dominant}

De lerarenpopulatie in Caribisch Nederland kan als bijzonder divers getypeerd worden als het gaat om de (geografische) herkomst. Dit volgt niet alleen uit hun geboorte(ei)landen (zoals we eerder zagen in Tabel 2.3), maar ook uit de 'routes' die leraren hebben doorlopen voordat zij op Bonaire, Sint Eustatius of Saba zijn gaan werken. Met 'route' bedoelen we de opeenvolging van (ei)landen waar men geboren is, waar men woonde op zestienjarige leeftijd en waar men de lerarenopleiding heeft gevolgd. Tabel 3.1 toont dit voor alle leraren van wie deze routes 'gereconstrueerd' konden worden. ${ }^{16}$ De routes zijn gespecificeerd naar het eiland waar de leraren nu werken: ofwel Bonaire ofwel Sint Eustatius/Saba.

Tabel 3.1 - Meest voorkomende 'routes' die leraren ${ }^{17}$ in Caribisch Nederland hebben doorlopen

\begin{tabular}{|c|c|c|c|}
\hline \multicolumn{4}{|c|}{ Werkzaam op: Bonaire $(n=107)$} \\
\hline Geboren & 16 jaar oud & Lerarenopleiding & Percentage \\
\hline Europees Nederland & Europees Nederland & Europees Nederland & $48 \%$ \\
\hline Suriname & Suriname & Suriname & $7 \%$ \\
\hline Bonaire & Bonaire & Curaçao & $6 \%$ \\
\hline Bonaire & Bonaire & Europees Nederland & $5 \%$ \\
\hline Curaçao & Curaçao & Curaçao & $5 \%$ \\
\hline \multirow[t]{2}{*}{ Bonaire } & Bonaire & Bonaire & $4 \%$ \\
\hline & overige 'routes' & & $26 \%$ \\
\hline Totaal & & & $100 \%$ \\
\hline \multicolumn{4}{|c|}{ Werkzaam op: Sint Eustatius of Saba $(n=32)$} \\
\hline Geboren & 16 jaar oud & Lerarenopleiding & Percentage \\
\hline \multirow[t]{2}{*}{ Europees Nederland } & Europees Nederland & Europees Nederland & $53 \%$ \\
\hline & overige 'routes' & & $47 \%$ \\
\hline Totaal & & & $100 \%$ \\
\hline
\end{tabular}

16. Niet alle respondenten hebben informatie verschaft waar men geboren is, waar men woonde op zestienjarige leeftijd en waar men de lerarenopleiding heeft gevolgd. Beantwoording van deze vraag was niet verplicht.

17. Het gaat hier alleen om leraren, dat wil zeggen exclusief de andere (lesgevende) functies. 


\section{Bonaire}

Op Bonaire is veruit de meest voorkomende 'migratieroute' voor leraren Europees Nederland $\rightarrow$ Europees Nederland $\rightarrow$ Europees Nederland $\rightarrow$ Bonaire. Bijna de helft van de leraren op Bonaire (48\%) is geboren en opgegroeid in Europees Nederland en heeft daar ook de lerarenopleiding gevolgd. Andere routes die in veel mindere mate, maar nog steeds veelvuldig voorkomen zijn een volledig Surinaamse route (Suriname $\rightarrow$ Suriname $\rightarrow$ Suriname $\rightarrow$ Bonaire: 7\%) en de routes waarin men in Bonaire of Curaçao is geboren of opgegroeid, en in Europees Nederland of Curaçao de lerarenopleiding heeft gevolgd: Bonaire $\rightarrow$ Bonaire $\rightarrow$ Curaçao $\rightarrow$ Bonaire (6\%); Bonaire $\rightarrow$ Bonaire $\rightarrow$ Europees Nederland $\rightarrow$ Bonaire (5\%) en Curaçao $\rightarrow$ Curaçao $\rightarrow$ Curaçao $\rightarrow$ Bonaire (5\%). Slechts een klein deel van de leraren heeft een volledige Bonaire-'route' voltooid (4\%)..$^{18}$ Overigens heeft ook een fors deel $(26 \%)$ andere 'routes' doorlopen. Het gaat dan om zeer uiteenlopende routes.

De connectie tussen Bonaire en Europees Nederland kan - in termen van (leraren)migratie - als zeer sterk getypeerd worden. Bijna zeven op de tien leraren zijn in Europees Nederland geboren en/of woonden er op zestienjarige leeftijd en/of hebben er de lerarenopleiding gevolgd.

\section{Sint Eustatius en Saba}

Op Sint Eustatius en Saba is het migratiebeeld diffuser dan op Bonaire. Weliswaar heeft ook op deze eilanden ongeveer de helft van de leraren $(53 \%)$ de volledig 'Europees Nederlandse' route doorlopen (dat wil zeggen Europees Nederland $\rightarrow$ Europees Nederland $\rightarrow$ Europees Nederland $\rightarrow$ Sint Eustatius of Saba), de resterende helft $(47 \%)$ heeft uiteenlopende andere 'routes' gevolgd. Er is in de migratiestromen geen tweede 'grote route' te herkennen, veel routes zijn uniek. Ook als we ons alléén richten op de plek waar men de lerarenopleiding heeft gevolgd, is er geen sterk vertegenwoordigde tweede (deel)route waar te nemen. Als we de Europese Nederlanders namelijk buiten beschouwing laten (geen van hen heeft de opleiding buiten Europees Nederland gevolgd) dan blijkt de variatie onder de leraren zeer groot. Leraren die niet zijn geboren in Europees Nederland hebben hun opleidingen bijvoorbeeld gevolgd op Curaçao, op de Amerikaanse Maagdeneilanden, op Guyana, op Jamaica, in Canada of in Europees Nederland. Geen van deze 'opleidings(ei)landen' is procentueel sterk vertegenwoordigd.

Ook op Sint Eustatius en Saba is er dus weliswaar sprake van een duidelijke connectie - in termen van (leraren)migratie - met Europees Nederland, maar minder prominent dan op Bonaire. De connectie bestaat vooral vanwege de aanwezigheid van de Europese Nederlanders: bijna zes op de tien leraren die werkzaam zijn op Sint Eustatius of Saba, is in Europees Nederland geboren.

18. Dit is overigens niet verwonderlijk, aangezien er op Bonaire zelf geen instelling is die een lerarenopleiding biedt. Slechts bij voldoende lokale aanmeldingen kan de lerarenopleiding van de Universiteit van Curaçao gevolgd worden op een dependance op Bonaire. 


\subsubsection{Immigratie vooral vanwege werk}

In de voorgaande subparagraaf zagen we dat een zeer groot deel van de lerarenpopulatie op een bepaald moment in hun leven ge(r)emigreerd is naar Bonaire, Sint Eustatius of Saba. De vraag die hierbij rijst is waarom men op een gegeven moment naar Caribisch Nederland is (terug)gekomen. Figuur 3.1 toont voor de gehele responsgroep ${ }^{19}$ de belangrijkste reden om naar het eiland te komen waar men nu werkt. Let wel: het gaat hier dus om de hoofdreden om naar het eiland te komen, natuurlijk kan men ook andere aanvullende motieven hebben.

Twee derde van de respondenten (65\%) geeft aan dat zij (vooral) naar het eiland zijn verhuisd om er te gaan werken. Twee tiende heeft altijd al op het eiland gewoond $(8 \%)$ of wilde terugkeren naar het eiland waar ze oorspronkelijk vandaan komen ${ }^{20}$ (12\%). Bijna één op de tien respondenten (9\%) geeft aan meeverhuisd te zijn met de partner en/of de familie. De overige respondenten (5\%) geven onder meer aan te zijn verhuisd om te kunnen reizen, voor het klimaat of vanwege de uitdaging.

Figuur 3.1 - Wat was voor u de belangrijkste reden om naar het eiland te komen waar u nu werkt? $(n=196)$

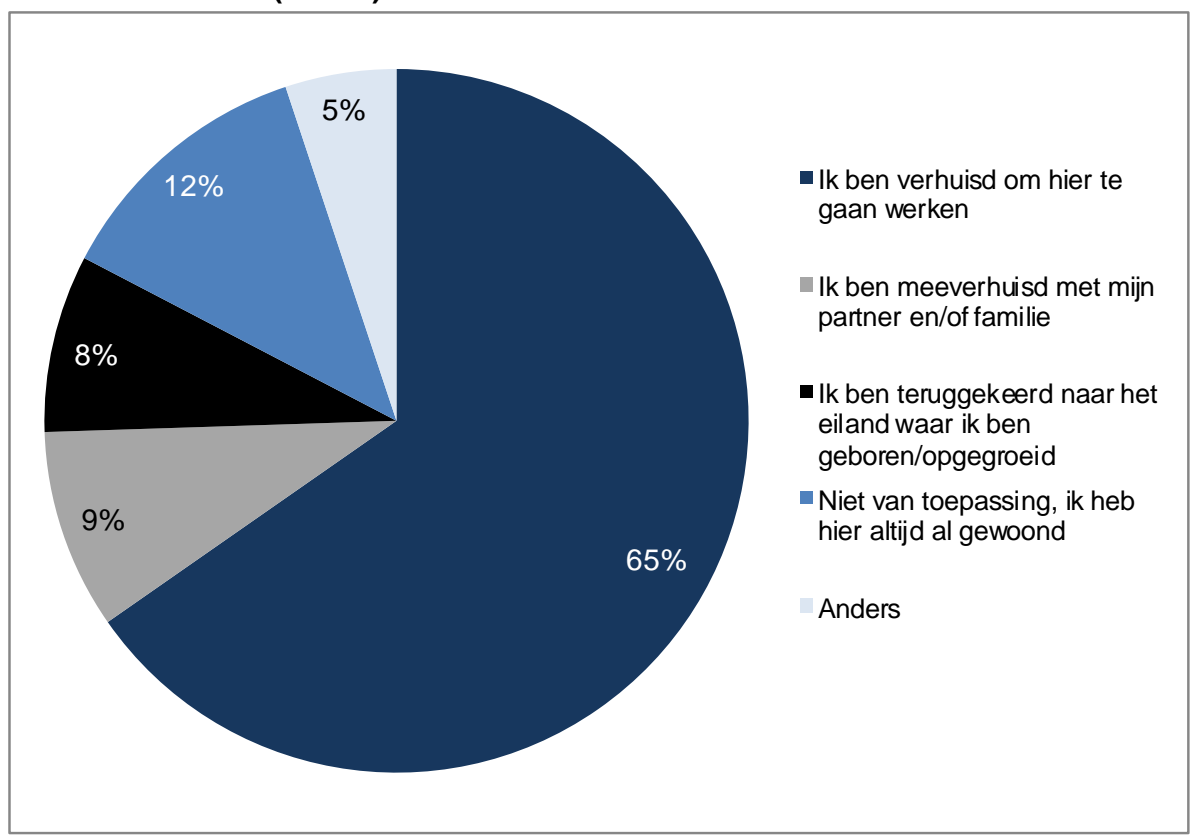

Bron: Enquête lerarenmobiliteit Caribisch Nederland, ROA (2016)

Het belangrijkste motief om naar het eiland te komen waar men nu werkt, verschilt naar geboorte(ei)land. Zo is terugkeer naar het eiland waar men eerder gewoond heeft voor (van geboorte) Caribische Nederlanders logischerwijs veel vaker het

19. Vanaf dit punt in de analyses zal in de basis uitgegaan worden van de totale responsgroep, oftewel zowel leraren als andere lesgevende functies.

20. Deze antwoordcategorie is gedestilleerd uit de open antwoorden bij deze vraag, zoals genoemd bij 'anders, namelijk'. 
belangrijkste migratiemotief. Uit regressieanalyse volgt verder dat leraren iets minder vaak dan andere functies aangeven dat terugkeer naar hun eiland de belangrijkste migratiereden was (zie Bijlage A: Regressieanalyses).

\subsubsection{Caribisch leven belangrijke reden om te komen werken}

Aan respondenten die aangeven dat ze vooral vanwege het werk naar het eiland zijn gekomen, is gevraagd wat hier zoal belangrijke redenen voor zijn (meerdere antwoorden mogelijk). De meest genoemde redenen zijn weergegeven in Figuur 3.2: 'Ik wilde eens wat anders in mijn leven' (34\%), 'Het Caribische leven trok mij aan' (22\%) en 'Ik houd van avontuur' (22\%). De meest genoemde verhuismotieven gaan dus vooral over het willen wonen in en ervaren van Caribisch Nederland.

Figuur 3.2 - Redenen om naar Caribisch Nederland te komen om te werken, meerdere antwoorden mogelijk $(n=125)$

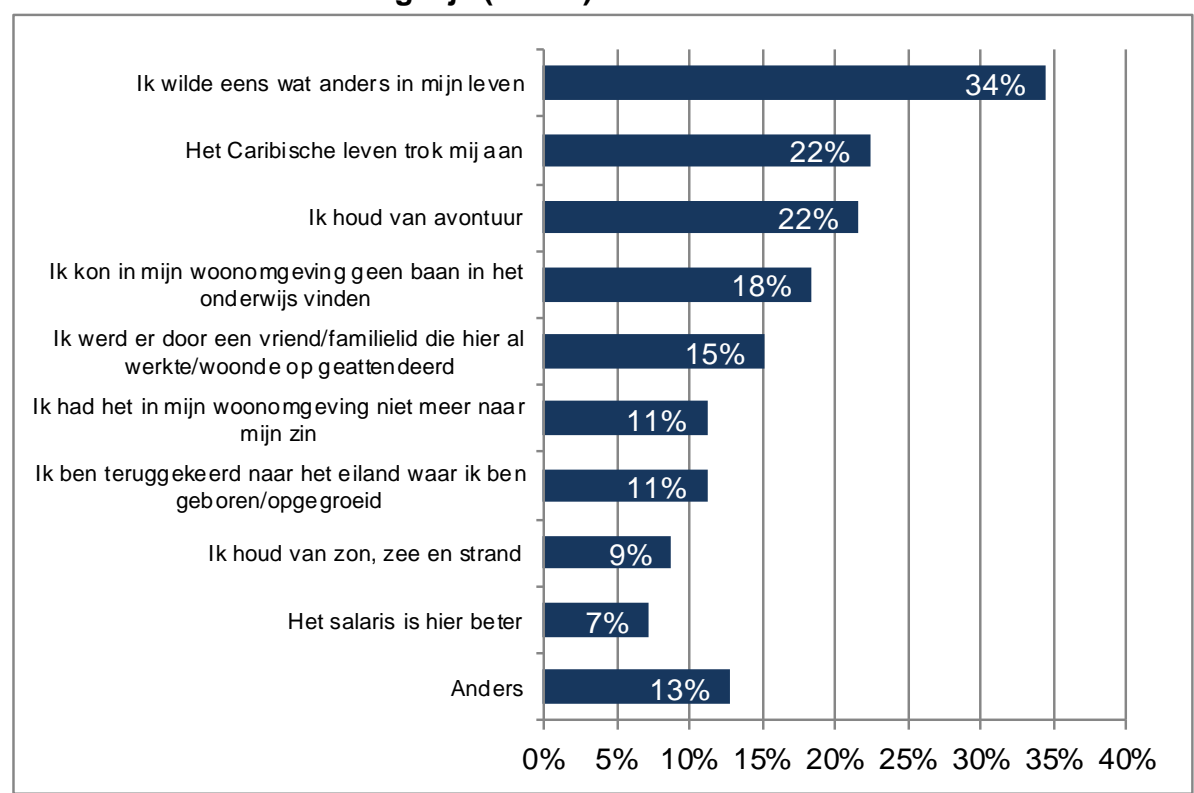

Bron: Enquête lerarenmobiliteit Caribisch Nederland, ROA (2016)

De meest genoemde redenen (zoals 'iets anders' willen, het avontuur opzoeken en het Caribische leven willen ervaren) hangen samen met het geboorte(ei)land, vooral wat betreft de voorkeuren van de Europese Nederlanders. Dit is duidelijk te zien in Figuur 3.3. Verreweg de meeste personen geboren op Bonaire, Sint Eustatius of Saba geven aan dat ze op het eiland zijn gaan werken omdat ze er oorspronkelijk vandaan komen (71\%). ${ }^{21}$ Deze Caribische Nederlanders geven meermaals aan dat ze onder meer terugkeren om een positieve bijdrage te leveren aan het onderwijs, omdat ze zich sterk betrokken voelen bij de ontwikkeling van het eiland. Hieruit blijkt dat de redenen om in Caribisch Nederland te komen werken sterk verschillen tussen

21. Deze antwoordcategorie is gedestilleerd uit de open antwoorden, zoals genoemd bij 'anders, namelijk'. 
de 'remigranten' en de 'immigranten'. Voor Caribische Nederlanders lijkt het vooral om het gevoel van betrokkenheid bij (of verantwoordelijkheid voor) het eiland te gaan waar zij vandaan komen. Voor 'immigranten' gaat het juist vooral om de uitdaging en 'nieuwigheid' van het leven in het Caribisch gebied.

Figuur 3.3 - Redenen om naar Caribisch Nederland te komen om te werken, meerdere antwoorden mogelijk, naar geboorte(ei)land $(n=125)$

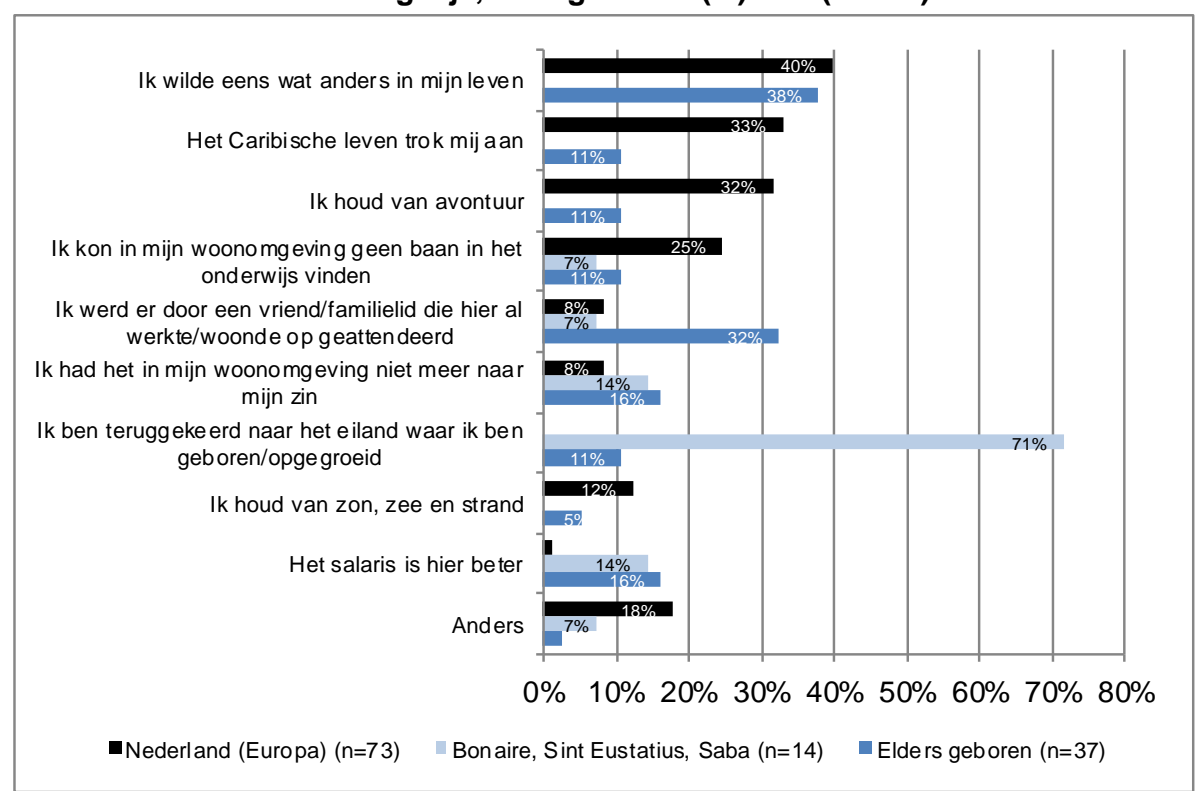

Bron: Enquête lerarenmobiliteit Caribisch Nederland, ROA (2016)

\subsection{Tevredenheid over informatie}

Respondenten die aangaven (vooral) naar het eiland te zijn gekomen om te werken, zijn gevraagd hoe tevreden zij zijn over de informatie die zij voorafgaand aan hun verhuizing hebben ontvangen. Het gaat hierbij om informatie over zowel de leefomstandigheden als de werkomstandigheden in Caribisch Nederland. Uit Figuur 3.4 volgt dat er vrij veel variatie is over hoe tevreden men is over de informatie. Zo geven enkele respondenten een 0 of een 1 (helemaal niet tevreden) en geven anderen juist een 9 of een 10 (helemaal tevreden). Het gros van de respondenten antwoordt echter tussen 5 en 8 . Men is gemiddeld positiever over de informatie over de leefomstandigheden $(6,3)$ dan over de informatie over de werkomstandigheden $(5,5)$. 
Figuur 3.4 - Op een schaal van 0-10: hoe tevreden bent u over de informatie die u voorafgaand aan uw aankomst heeft gekregen over de...

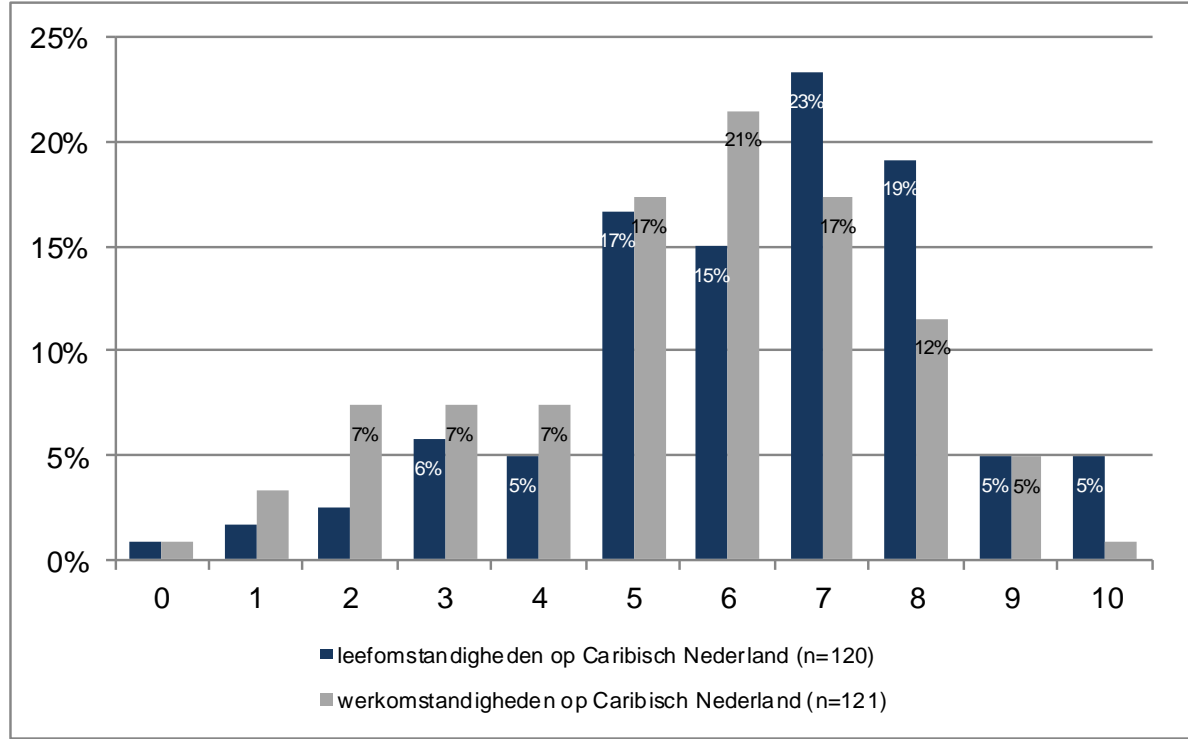

Bron: Enquête lerarenmobiliteit Caribisch Nederland, ROA (2016)

\subsubsection{Caribische Nederlanders meer tevreden over informatie}

In Figuur 3.5 zien we hoe de informatie over de leef- en werkomstandigheden beoordeeld wordt door Europese Nederlanders, Caribische Nederlanders en personen afkomstig van andere (ei)landen. Personen uit Bonaire, Sint Eustatius en Saba waarderen de informatie over de leef- en werkomstandigheden (gemiddeld) respectievelijk met een 7,9 en een 7,0. Respondenten die geboren zijn in Europees Nederland geven gemiddeld een 6,1 en 5,2; en respondenten die elders geboren zijn geven gemiddeld een 6,0 en 5,7. Het feit dat respondenten die geboren zijn in Caribisch Nederland meer tevreden zijn over de informatie is wellicht niet zo verrassend. Het is immers waarschijnlijk dat zij zelf al ervaring hebben met de omstandigheden op het eiland, of dat zij de benodigde informatie via hun eigen netwerk (familie, vrienden) kunnen inwinnen. 
Figuur 3.5 - Op een schaal van 0-10: hoe tevreden bent u over de informatie die u voorafgaand aan uw aankomst heeft gekregen over..., naar geboorte(ei)land

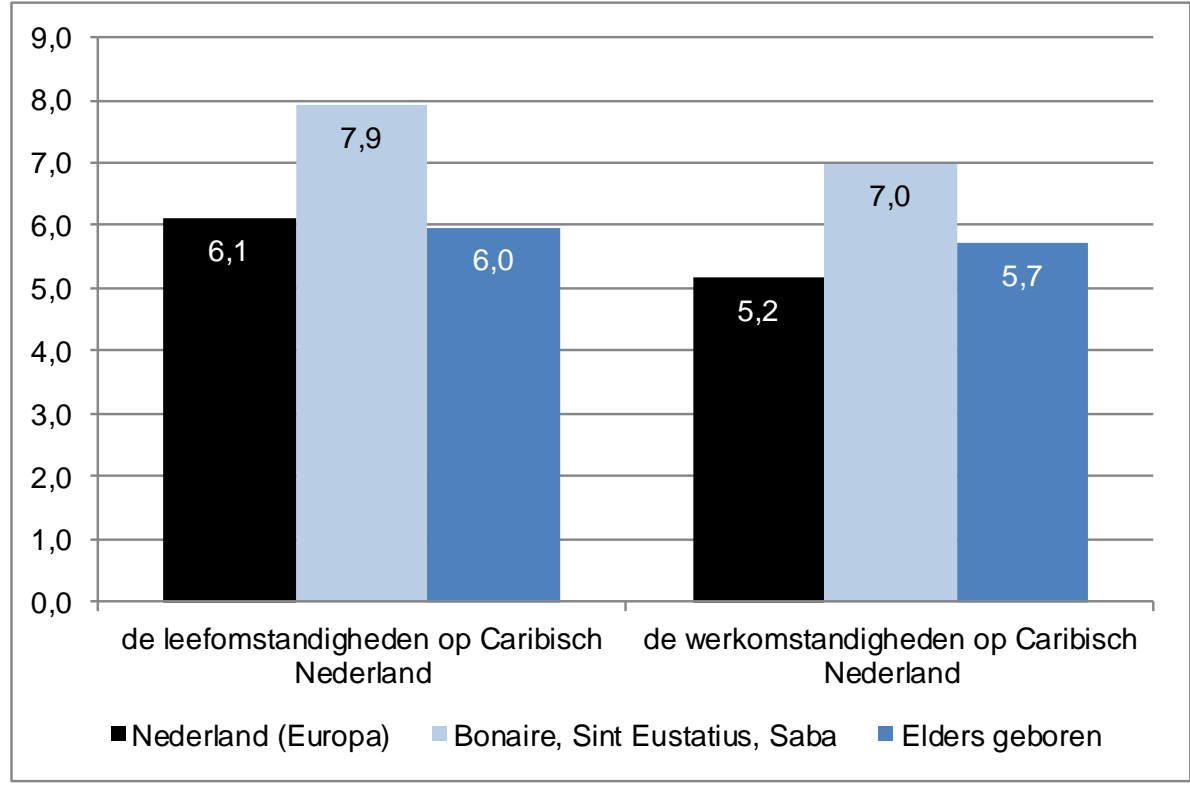

Bron: Enquête lerarenmobiliteit Caribisch Nederland, ROA (2016)

\subsubsection{Helft had meer informatie gewild over leef- en werkomstandigheden}

Uit Figuur 3.6 blijkt dat ongeveer de helft van de personen die naar het eiland zijn verhuisd om te gaan werken, (terugkijkend) meer informatie over de leef- en werkomstandigheden had willen ontvangen. Hierbij bestaat er vaker behoefte aan informatie over de werkomstandigheden (52\%) dan over de leefomstandigheden $(42 \%)$. 
Figuur 3.6 - Terugkijkend, had u meer informatie over de leef- en werkomstandigheden willen ontvangen?

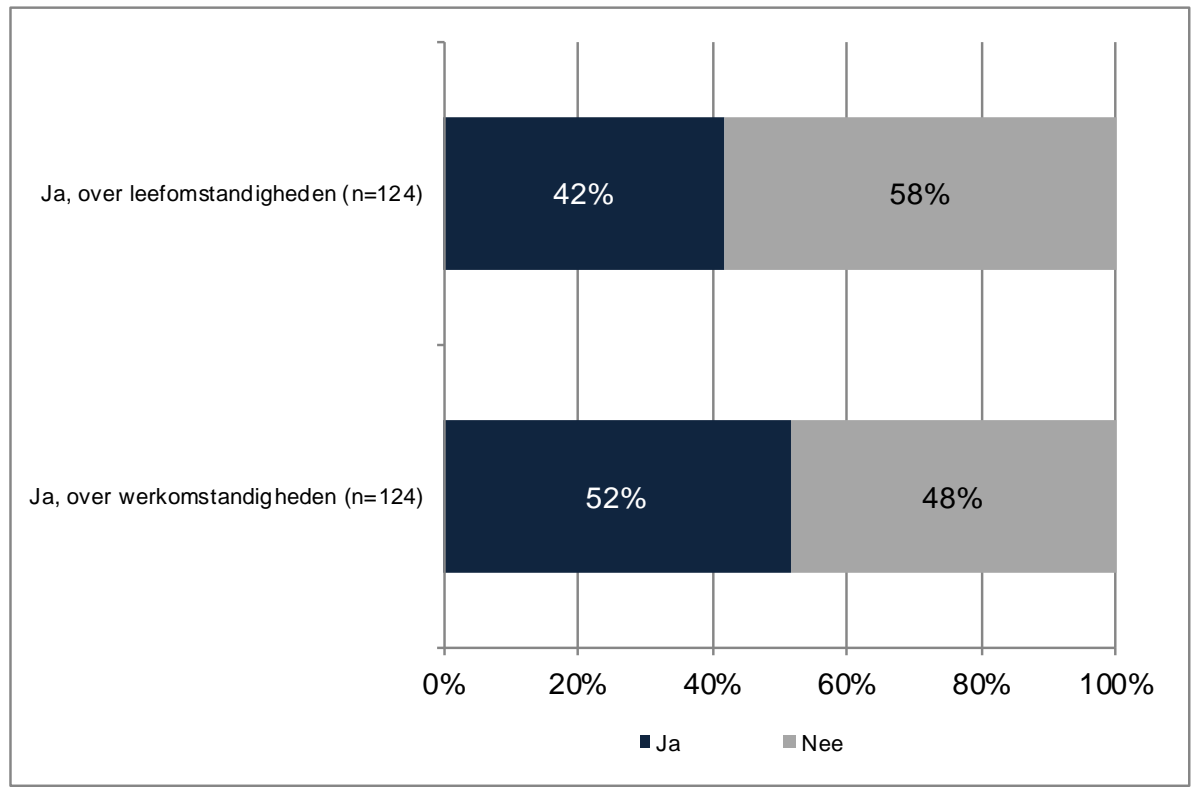

Bron: Enquête lerarenmobiliteit Caribisch Nederland, ROA (2016)

De behoefte aan extra informatie over de leef- en werkomstandigheden wordt vooral uitgesproken door respondenten die buiten Caribisch Nederland geboren zijn. Niet verrassend, aangezien we in Figuur 3.5 al zagen dat deze groep ook minder tevreden is over deze informatie. Onder de personen die geboren zijn in Europees Nederland had respectievelijk 47 en 54 procent, terugkijkend, meer informatie willen ontvangen over de leef- en werkomstandigheden. Onder personen die elders zijn geboren (niet in Caribisch of Europees Nederland) betreft het 38 en 51 procent. Hoewel personen die geboren zijn op Bonaire, Sint Eustatius of Saba relatief meer tevreden zijn over de ontvangen informatie, had toch nog een aanzienlijk deel (respectievelijk $29 \%$ en $36 \%$ ) van hen meer informatie willen krijgen over de leef- en werkomstandigheden. 
Figuur 3.7 - Terugkijkend, had u meer informatie over de leef- en werkomstandigheden willen ontvangen, percentage 'ja', naar geboorte(ei)land

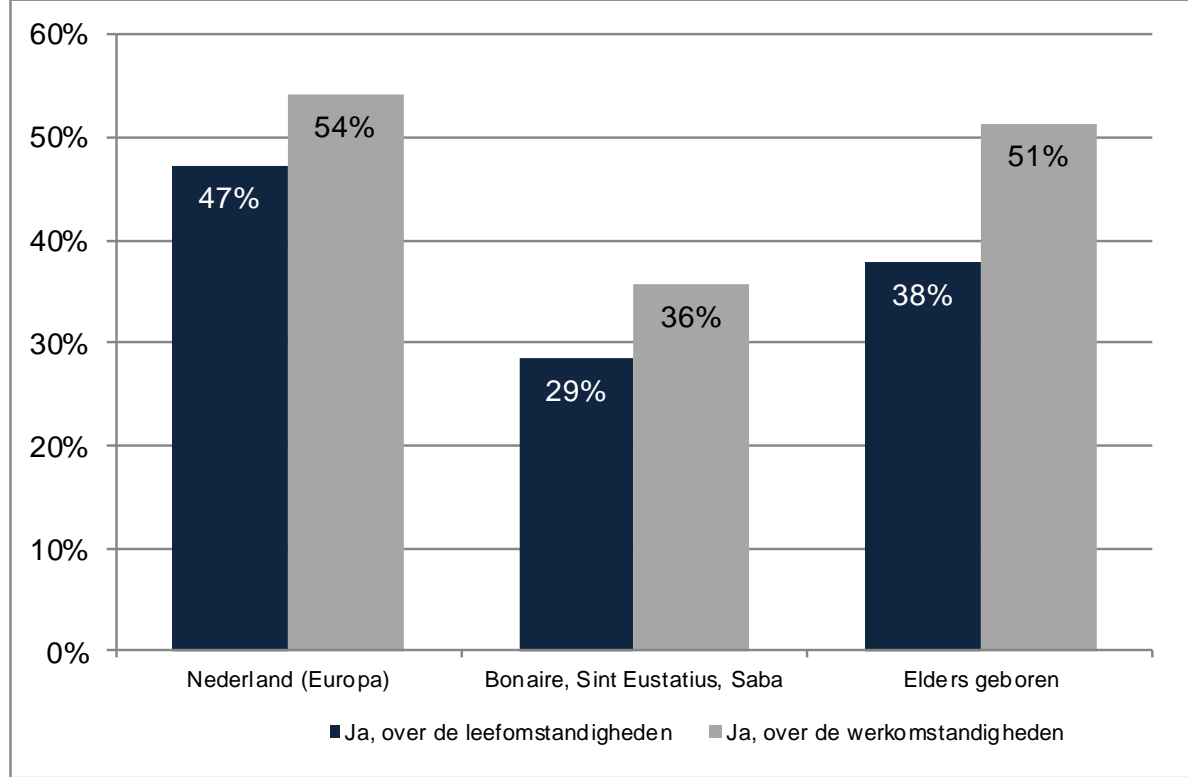

Bron: Enquête lerarenmobiliteit Caribisch Nederland, ROA (2016)

\subsubsection{Meer behoefte aan informatie over economische, culturele en onderwijs- context}

Een kwalitatieve analyse van het type informatie over de leefomstandigheden dat men vooral had gewenst, levert een gevarieerd beeld op. Er zijn hier ruwweg vier clusters te onderscheiden, namelijk informatie over de economische situatie, over de culturele context, over de immigratieprocedure en over het klimaat. In onderstaande tekstvak staan de meest genoemde aspecten binnen deze clusters beschreven. 


\section{Uitgelicht: informatie over leefomstandigheden}

Respondenten hadden wat betreft de economische situatie vooral beter voorgelicht willen worden over de hoge kosten van levensonderhoud (met name wonen), de mogelijke problemen bij het vinden van een geschikte woning, de schaarste van producten en diensten en de armoede die men om zich heen ziet.

Ten aanzien van de culturele context is meer informatie over de omgang tussen de 'locals' en immigranten gewenst. Zo voelen enkele Europese Nederlanders zich niet welkom of zelfs gediscrimineerd door de lokale bevolking. Ook wordt genoemd dat men meer kennis had gewild over de manier van denken en de religieuze gebruiken op het eiland.

Wat betreft de immigratie is er vooral behoefte aan informatie over de administratieve procedure: wat zijn de te doorlopen stappen bij immigratie, waar dient men zich tot te wenden, wat is nodig et cetera?

Tot slot geven diverse respondenten aan dat zij meer informatie over het klimaat hadden gewild. Zo kan men op de eilanden te maken krijgen met orkanen en hoge temperaturen.

Gewenste informatie over de werkomstandigheden heeft ruwweg betrekking op drie clusters, namelijk op de arbeidsvoorwaarden, op de sociaal-culturele context en op de onderwijscontext. Veelgenoemde aspecten die onder deze clusters vallen, zijn lezen in onderstaande tekstvak. 


\section{Uitgelicht: gewenste informatie over werkomstandigheden}

Betere voorlichting over de arbeidsvoorwaarden zou volgens de respondenten vooral moeten gaan over de lage salarissen en de salarisverschillen tussen po en vo/mbo. Ook had men meer informatie willen hebben over de pensioenvoorzieningen, de werktijden en het arbeidscontract.

Wat betreft de sociaal-culturele context op school had men vooral meer informatie gewild over de hoge werkdruk. Ook is de omgang met de leerlingen soms niet zoals verwacht. Zo heeft een respondent het gevoel dat leerlingen in de school op een voetstuk staan en de leraar er 'vogelvrij' wordt verklaard. Sommige leraren geven aan dat de regels en afspraken op school van tevoren niet helder waren en er sprake kan zijn van grote bureaucratie afkomstig van de schoolleiding.

Ten aanzien van de onderwijscontext geven verschillende leraren aan dat ze onvoldoende op de hoogte waren van de 'schamele' voorzieningen op school. Het gaat dan niet alleen om lesmaterialen, maar bijvoorbeeld ook om de airconditioning op school. Ook zijn diverse leraren verrast door de taalbeheersing van de leerlingen. Leerlingen beheersen de instructietaal niet altijd voldoende, waardoor er onverwachts geschakeld moet worden in taal. Verder geven verschillende leraren aan dat zij onvoldoende op de hoogte waren van het soms lage niveau van de leerlingen en het onderwijs in zijn geheel. Tot slot geven diverse leraren aan dat het onderwijsprogramma en de manier van les geven (zoals opstelling richting de leerling) erg verschilt tussen Europees en Caribisch Nederland, iets wat veel gewenning vereist en waar ze onvoldoende op voorbereid waren.

\subsection{Tevredenheid met baan en leven}

\subsubsection{Baantevredenheid is laag ten opzichte van tevredenheid met leven}

Het lesgevend personeel in Caribisch Nederland waardeert zijn baan gemiddeld met een 6,7. De variatie in de baantevredenheid is echter vrij groot, zo is te zien in Figuur 3.8. Enerzijds geeft 4 procent van het personeel zijn baan een 0 of een 1 (helemaal niet tevreden), terwijl andersom een relatief groot aandeel van 18 procent zijn baan een 9 of een 10 (helemaal tevreden) geeft. Ongeveer de helft (45\%) waardeert de baan met een 7 of en 8 .

De gemiddelde tevredenheid over het leven $(8,2)$ steekt hoog af tegen de baantevredenheid $(6,7)$. Het tevredenheidscijfer over het leven toont bovendien veel minder spreiding dan de baantevredenheid. Negen van de tien respondenten (89\%) waardeert het leven met een $7,8,9$ of 10, terwijl ruim een vijfde een onvoldoende geeft aan de baantevredenheid. 
Figuur 3.8 - Op een schaal van 0-10 (met 0 'helemaal niet tevreden' en 10 'helemaal tevreden'): hoe tevreden bent u over uw...

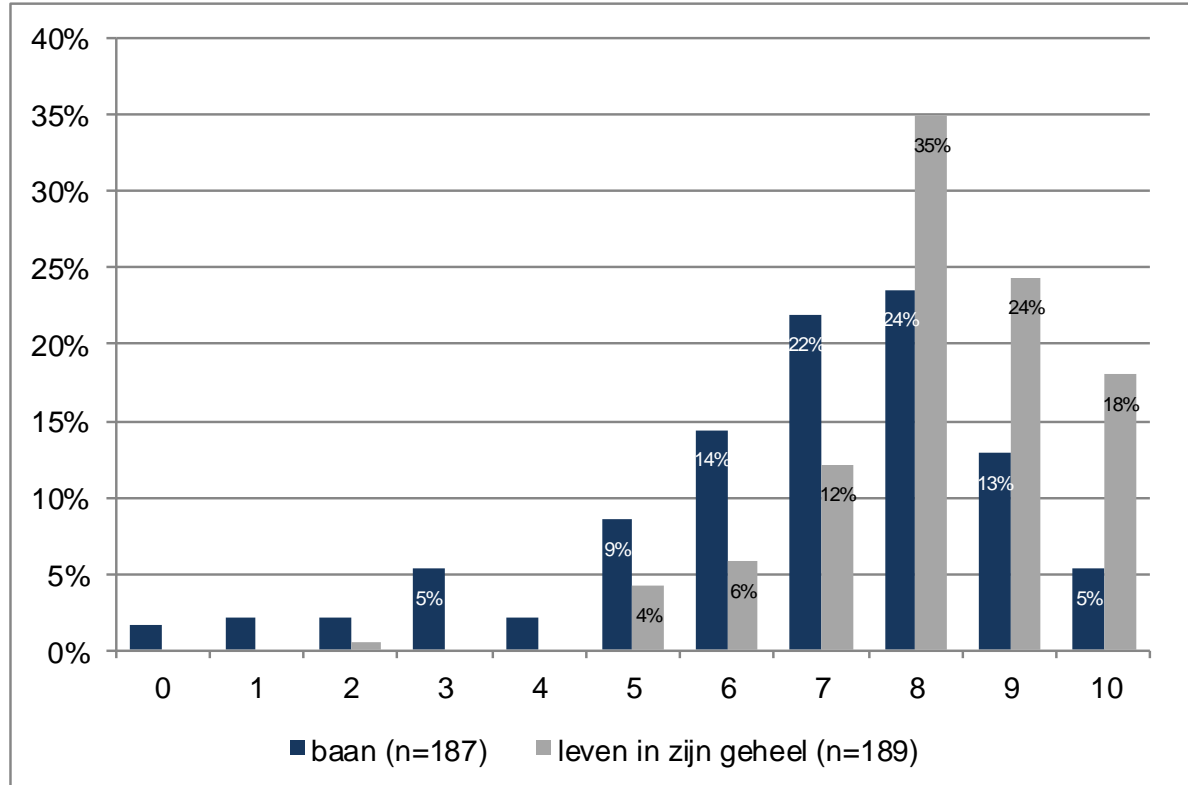

Bron: Enquête lerarenmobiliteit Caribisch Nederland, ROA (2016)

\subsubsection{Europese Nederlanders minst tevreden met baan}

Lesgevend personeel geboren in Europees Nederland is over het algemeen minder tevreden met hun baan, zo volgt uit Figuur 3.9. Zij geven hun baan gemiddeld een 6,1 . Personen die geboren zijn in Caribisch Nederland zijn het meest tevreden met een gemiddelde van 7,6. Personen die elders geboren zijn zitten tussen beide scores in met een gemiddelde van 7,0. Verschillen in de levenstevredenheid naar geboorte(ei)land zijn veel kleiner en wijken niet significant af. 
Figuur 3.9 - Op een schaal van 0-10 (met 0 'helemaal niet tevreden' en 10 'helemaal tevreden'): hoe tevreden bent u over uw..., naar geboorte(ei)land

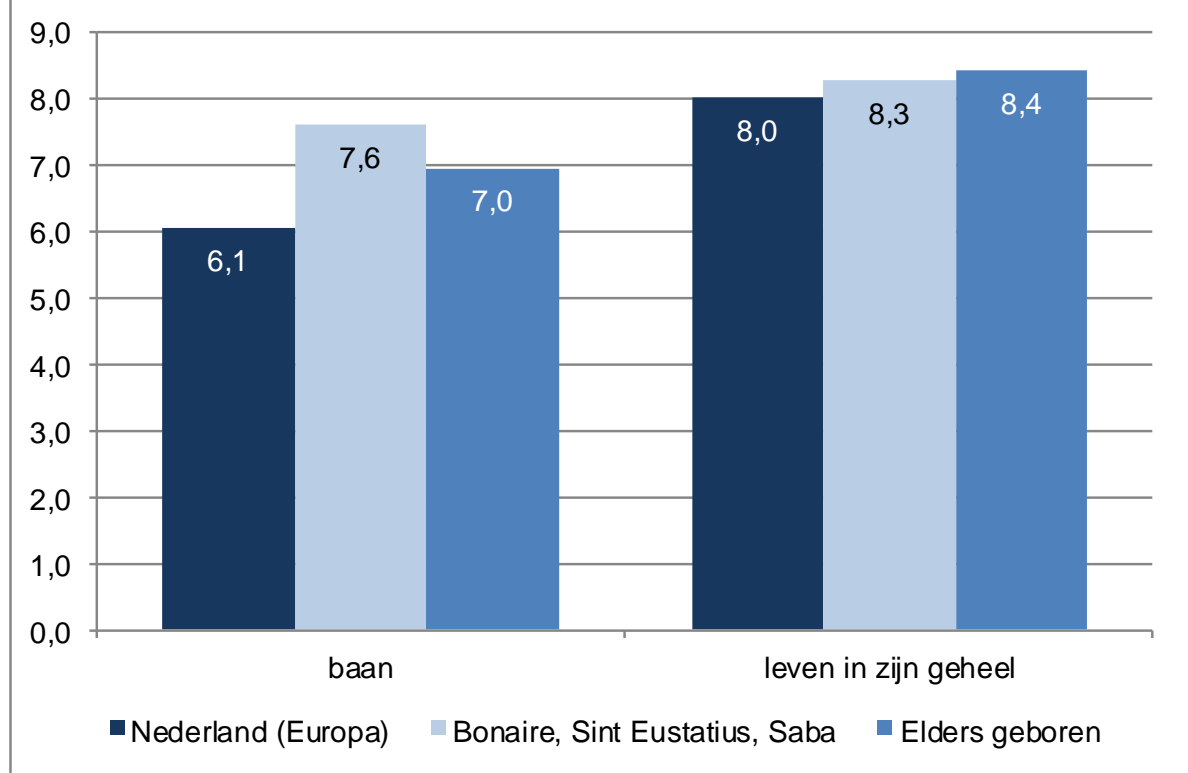

Bron: Enquête lerarenmobiliteit Caribisch Nederland, ROA (2016)

Naast verschillen in de gemiddelde baantevredenheid naar geboorte(ei)land, zijn er ook significante verschillen naar onderwijssector. In het po is men met een 7,3 gemiddeld een vol punt meer tevreden over de huidige baan dan in het vo/mbo, waar men gemiddeld een 6,2 geeft. 


\section{Pull- en pushfactoren}

In dit hoofdstuk richten we de aandacht op de redenen voor lesgevend personeel om in hun huidige baan te blijven ('pulffactoren') en de redenen om de huidige baan te verlaten ('pushfactoren'). Eerst kijken we naar het totaaloverzicht van relevante pullfactoren, om vervolgens in te zoomen op de - voor de respondent - belangrijkste reden om in de huidige baan te blijven. Vervolgens kijken we naar het totaaloverzicht van genoemde pushfactoren, om daarna in te zoomen op de belangrijkste vertrekreden. Ook is er in dit hoofdstuk aandacht voor de toekomstverwachtingen van lesgevend personeel: hoe lang verwachten zij les te blijven geven, en in het onderwijs en in Caribisch Nederland te blijven werken?

\subsection{Redenen om in baan te blijven ('pullfactoren')}

\subsubsection{Leven op het eiland, goede band met leerlingen en uitdagend werk meest genoemde redenen om in baan te blijven}

Figuur 4.1 toont welke redenen het lesgevend personeel vooral noemt om in de huidige baan te blijven (men kon meerdere antwoorden aanvinken We maken hierbij niet alleen onderscheid tussen Bonaire enerzijds ('benedenwinds') en Sint Eustatius en Saba anderzijds ('bovenwinds'), omdat de eilanden van elkaar verschillen qua omvang, cultuur en onderwijssysteem ${ }^{22}$ maar ook omdat de enquêteresultaten significante verschillen in de genoemde blijfredenen laten zien. Sommige blijfredenen worden vaker op Bonaire genoemd, andere vaker op Sint Eustatius en Saba. De blijfredenen zijn voor het gemak geclusterd onder de kopjes 'arbeidsvoorwaarden en -omstandigheden', 'leefomstandigheden' en 'sociaal netwerk'. Binnen alle clusters vinden we redenen die vaak genoemd worden door de respondenten. ${ }^{23}$

Onder de 'arbeidsvoorwaarden en -omstandigheden' zien we een hoog percentage respondenten (in totaal 70\%) voor wie hun goede band met de leerlingen een reden is om in de huidige baan te blijven. Met name op Sint Eustatius en Saba wordt dit zeer vaak genoemd, namelijk 81 procent tegen 67 procent op Bonaire. Andere werkgerelateerde redenen die zowel op Bonaire als op Sint Eustatius en Saba zijn genoemd, zijn: 'Mijn werk is uitdagend' (in totaal door $56 \%$ genoemd), 'Ik heb een goede band met de ouders van de leerlingen' (41\%), 'De samenwerking met de collega's is plezierig' (40\%) en 'Het salaris is goed' (32\%). De pullfactor 'Ik heb een vast dienstverband' wordt in totaal ook vaak genoemd (41\%), maar wordt op Bonaire (46\%) bijna twee keer zo vaak genoemd als op Sint Eustatius en Saba (24\%). Een opvallende bevinding, aangezien er tussen Bonaire en Sint Eustatius / Saba geen significante verschillen zijn in het percentage respondenten dat een vast dienstverband heeft.

22. In hoofdstuk 5 komen enkele verschillen in het onderwijs op Bonaire, Sint Eustatius en Saba aan de orde.

23. Voor een totaaloverzicht van de percentages voor alle genoemde pullfactoren, zie Bijlage B: Tabellenboek. 
Onder het clusters 'leefomstandigheden' zien we dat zeer veel respondenten (in totaal $78 \%$ ) in hun baan willen blijven, omdat dat ze het leven op hun eiland prettig vinden. Op Bonaire wordt dit vaker genoemd (81\%) dan op Sint Eustatius en Saba (69\%). Andersom wordt op Sint Eustatius en Saba opvallend veel vaker de blijfreden 'Er is weinig criminaliteit' genoemd (55\%) dan op Bonaire (28\%). Ook wordt 'De sociale controle op het eiland biedt bescherming' op Saba en Sint Eustatius aanzienlijk vaker als blijfreden genoemd (31\%) dan op Bonaire (18\%). De recreatiemogelijkheden worden daarentegen weer door veel personen op Bonaire genoemd (17\%) als reden om te blijven, terwijl dit door geen van de respondenten op Sint Eustatius en Saba wordt aangegeven.

Wanneer we kijken naar de redenen onder het kopje 'sociaal netwerk', dan blijkt ruim de helft van het lesgevende personeel (in totaal 51\%) het gevoel van verbondenheid met het eiland een belangrijke blijfreden te vinden, Op Bonaire wat vaker (54\%) dan op Sint Eustatius en Saba (43\%). Vier tiende (41\%) noemt het hebben van sociale contacten een reden om in de huidige baan te blijven. Er zijn hier nauwelijks verschillen tussen Bonaire enerzijds en Sint Eustatius en Saba anderzijds. Wel zien we verschillen bij de pullfactor 'Mijn partner heeft hier werk', dit wordt op Bonaire door $33 \%$ genoemd, tegen $24 \%$ op Sint Eustatius en Saba.

De verschillen tussen Bonaire enerzijds en Sint Eustatius en Saba anderzijds lijken voor een belangrijk deel te herleiden tot de omvang van de eilanden. Zo worden op het grotere Bonaire de recreatiemogelijkheden bijvoorbeeld genoemd als aantrekkelijke factoren, terwijl op het kleinschalige Sint Eustatius en Saba juist de sociale controle worden gewaardeerd.

Een klein deel van de respondenten (5\%) geeft tot slot aan geheel geen redenen te hebben om in de huidige baan te blijven. Uit nadere regressieanalyse (zie Bijlage A: Regressieanalyses) volgt dat het hier niet om een specifieke groep gaat wat betreft de achtergrondkenmerken (zoals functie, eiland, sector, geboorte(ei)land et cetera). Anders gezegd: er zijn géén specifieke groepen te onderscheiden die vaker aangeven dat ze geen 'blijfreden' hebben. 
Figuur 4.1 - Veelgenoemde redenen om in huidige baan te blijven, naar eiland, meerdere antwoorden mogelijk $(n=189)$

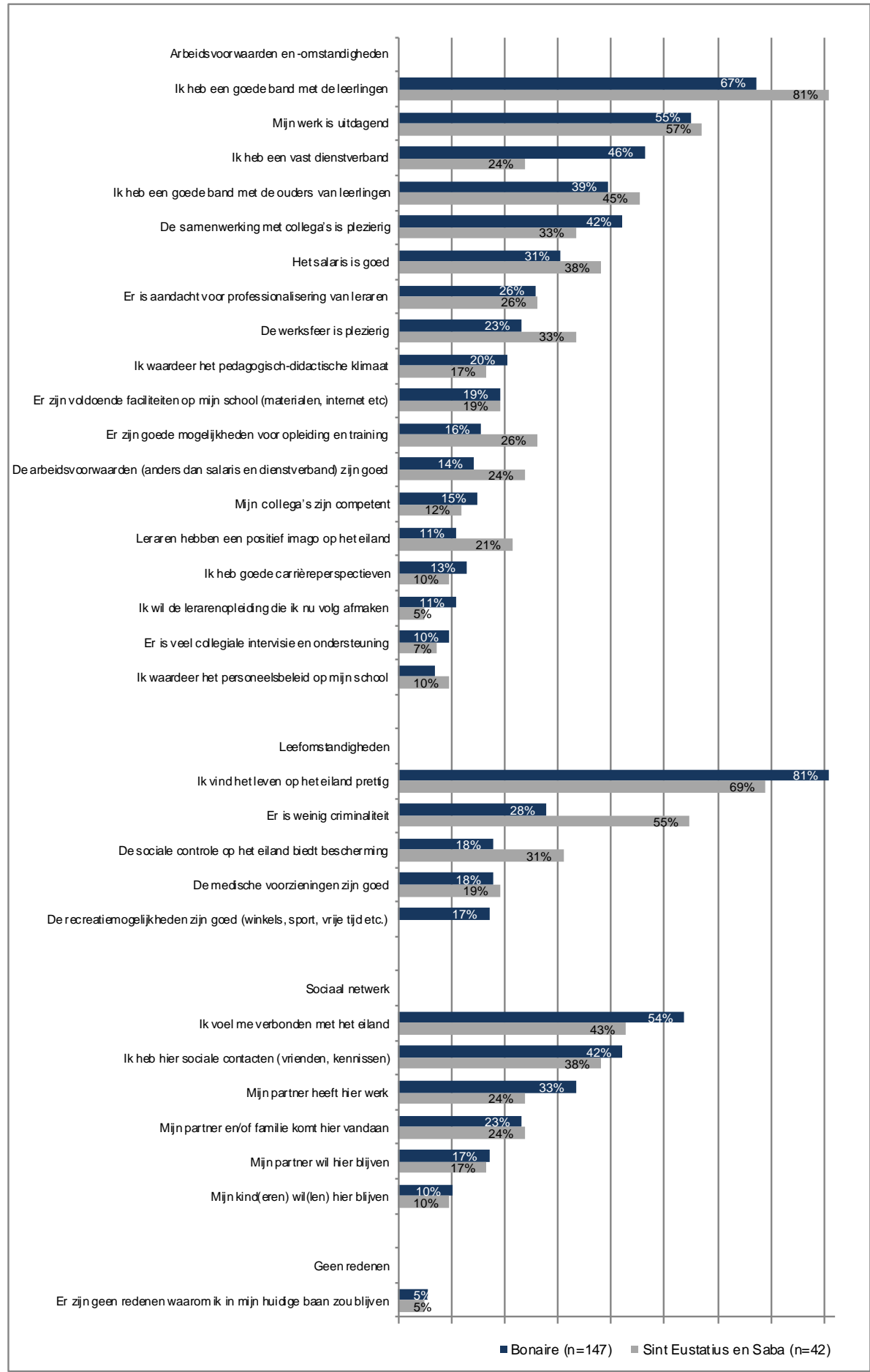

NB: Alleen redenen die door $\mathbf{1 0} \%$ van respondenten op Bonaire óf Sint Eustatius/Saba zijn genoemd Bron: Enquête lerarenmobiliteit Caribisch Nederland, ROA (2016) 


\subsubsection{Belangrijkste pullfactor vaak werkgerelateerd, specifieke redenen sterk variërend}

Nadat het lesgevende personeel gevraagd is naar alle mogelijke redenen om in de huidige baan te blijven, is gevraagd naar de voor hen belangrijkste reden. De pullfactor die door respondenten het belangrijkst wordt geacht, varieert sterk. Geen van de belangrijkste 'blijfredenen' springt er uit. De reden die het vaakst wordt genoemd, namelijk door één op de vijf respondenten (19\%), is 'Mijn werk is uitdagend'. Ook wordt vrij vaak als belangrijkste reden genoemd: 'Ik heb een goede band met de leerlingen' en ' $k$ vind het leven op het eiland prettig' (beide 13\%). De overige redenen (allemaal minder dan $5 \%$ genoemd) vormen tezamen de helft van de gegeven antwoorden (50\%). ${ }^{24}$ Tot slot geeft 5 procent aan, zoals eerder gezegd, geheel geen redenen te hebben om in de baan te blijven.

Aangezien er zeer veel verschillende redenen als 'het belangrijkst' genoemd worden om in de baan te willen blijven, zijn de redenen in Figuur 4.2 samengevoegd onder de drie clusters 'arbeidsvoorwaarden en -omstandigheden', 'leefomstandigheden' en 'sociaal netwerk'. Hieruit volgt dat voor twee derde van de respondenten (66\%) de belangrijkste 'blijfreden' te maken heeft met het werk zelf. Het kan dan zowel gaan over de arbeidsvoorwaarden (bijvoorbeeld een vast contract of professionaliseringsmogelijkheden), over de werkinhoud (bijvoorbeeld een uitdagende baan) of over de werkomgeving (bijvoorbeeld fijne collega's).

Voor 18 procent van de respondenten is de belangrijkste reden gerelateerd aan de leefomstandigheden (zoals het prettige eilandleven en de lage criminaliteit) en voor 16 procent heeft de belangrijkste 'blijfreden' te maken met het sociale netwerk (zoals het hebben van een partner met een baan op het eiland).

24. Een volledig overzicht van de 'belangrijkste pullfactor' kan gevonden worden in Bijlage B: Tabellenboek. 
Figuur 4.2 - Welke van de genoemde redenen om in uw huidige baan te blijven, is het belangrijkst, 3 hoofdclusters $(n=163)$

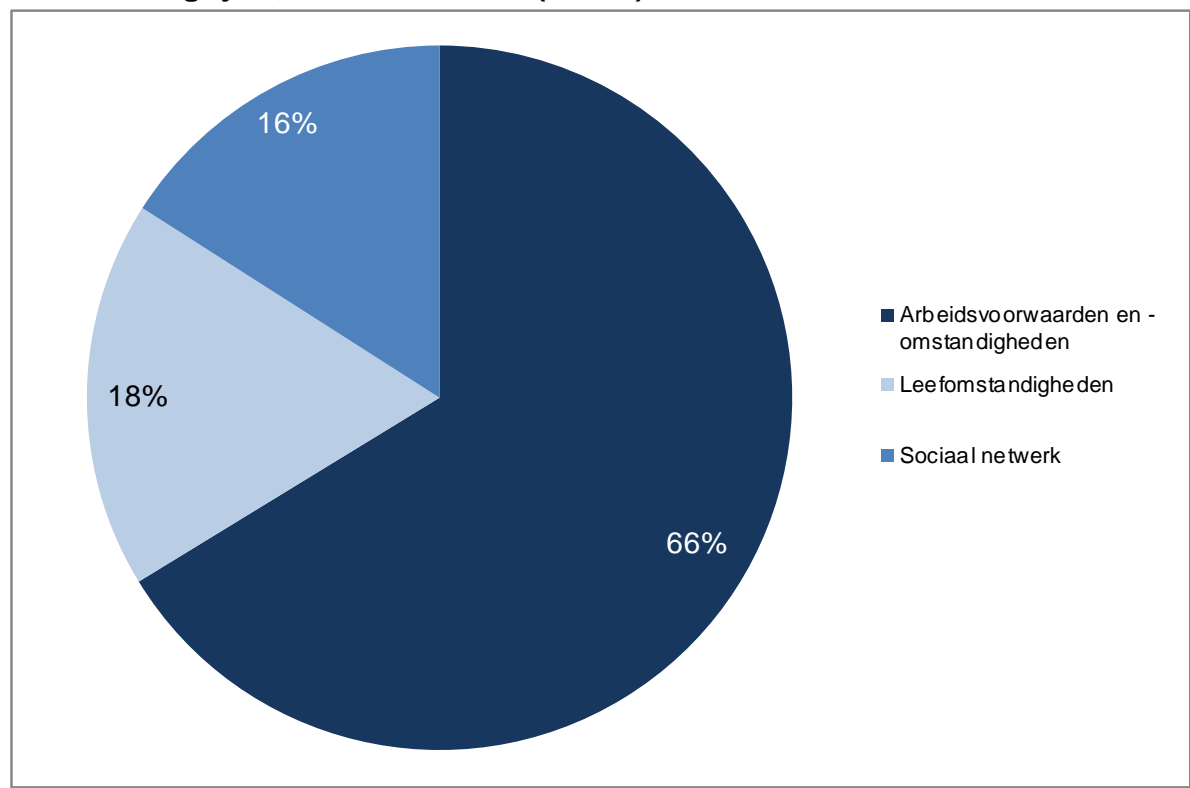

NB: Exclusief 'Er zijn geen redenen waarom ik in mijn huidige baan zou blijven' en open antwoorden

Bron: Enquête lerarenmobiliteit Caribisch Nederland, ROA (2016)

Een nadere specificatie van Figuur 4.2 naar geboorte(ei)land vinden we in Figuur 4.3. Personen die geboren zijn op Bonaire, Sint Eustatius of Saba noemen aanzienlijk vaker dan anderen een werkgerelateerde hoofdreden (zoals een vast contract) om in de baan te blijven, namelijk in 84 procent van de gevallen. Onder personen die niet op deze eilanden geboren zijn, ligt het percentage op ongeveer 60 procent.

Andersom zien we dat personen die geboren zijn in Caribisch Nederland zelden aangeven dat de leefomstandigheden voor hen de belangrijkste reden is om in de baan te blijven. Onder personen die elders geboren zijn ligt het percentage boven de 20 procent. De grote verschillen in percentages laten zich mogelijk verklaren doordat personen uit Caribisch Nederland niet specifiek kiezen om op hun eiland te wonen vanwege het 'eilandkarakter' (zoals het klimaat of recreatie), maar simpelweg omdat het hun 'thuis' is waar ze ook naar een andere baan zouden kunnen zoeken. 
Figuur 4.3 - Welke van de genoemde redenen om in uw huidige baan te blijven, is het belangrijkst, 3 hoofdclusters, naar geboorte(ei)land $(n=162)$

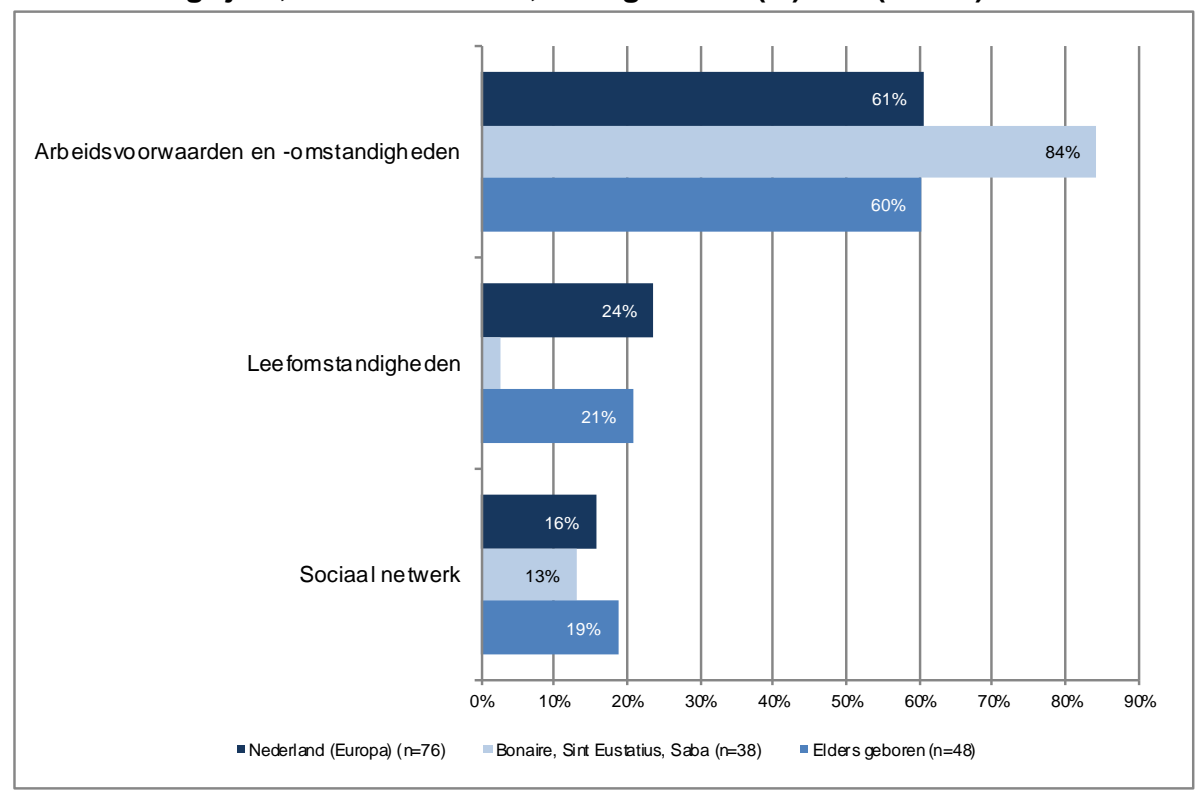

NB: Exclusief 'Er zijn geen redenen waarom ik in mijn huidige baan zou blijven' en open antwoorden Bron: Enquête lerarenmobiliteit Caribisch Nederland, ROA (2016)

Naast verschillen naar geboorte(ei)land wat betreft de belangrijkste 'blijfreden', blijken er ook verschillen te bestaan tussen leraren en andere functies. Leraren geven vaker dan anderen aan dat de leefomstandigheden voor hen de belangrijkste reden is $(21 \%$ onder leraren, $6 \%$ onder andere functies). Ook wanneer in regressieanalyse gecontroleerd wordt voor overige (samenhangende) kenmerken zoals het geboorte(ei)land, blijken leraren relatief vaker de leefomstandigheden als hoofdreden te noemen (Bijlage A: Regressieanalyses). Er blijken geen significante verschillen te bestaan wat betreft de belangrijkste vertrekreden tussen Bonaire enerzijds en Sint Eustatius en Saba anderzijds.

\subsection{Redenen om baan te verlaten ('pushfactoren')}

\subsubsection{Werkdruk en hoge kosten van levensonderhoud veelgenoemde redenen om baan te verlaten}

In Figuur 4.4 zien we de meest genoemde redenen om de huidige baan te verlaten (meerdere antwoorden mogelijk), waarbij weer onderscheid is gemaakt tussen respondenten op Bonaire enerzijds en op Sint Eustatius en Saba anderzijds. De keuze voor dit onderscheid is niet alleen op inhoudelijke gronden gemaakt (zoals verschillen in schaalgrootte), maar ook omdat er significante verschillen gevonden worden tussen de vertrekredenen die op enerzijds Bonaire en anderzijds Sint Eustatius en Saba genoemd worden. Ook in deze figuur zijn de redenen geclusterd naar 'arbeidsvoorwaarden en -omstandigheden', 'leefomstandigheden' en 'sociaal 
netwerk. ${ }^{25}$ Vergeleken met de eerdere figuur over 'blijfredenen' (Figuur 4.1), valt op dat de genoemde 'vertrekredenen' veel gevarieerder zijn. Anders gezegd: er zijn nauwelijks pushfactoren die eruit springen onder het lesgevend personeel. Bij de 'blijfredenen' was dit veel sterker het geval (zo noemde maar liefst $78 \%$ de reden 'Ik vind het leven op het eiland prettig').

Onder het cluster 'arbeidsvoorwaarden en -omstandigheden' zien we dat dat de (hoge) werklast / werkdruk een veelgenoemde reden is om de huidige baan te verlaten (door in totaal $37 \%$ van de respondenten). Wel wordt dit op Bonaire door een groter deel als vertrekreden genoemd: 40 procent tegenover 29 procent op Sint Eustatius en Saba. Andere werkgerelateerde redenen die door minstens één op de vijf respondenten zijn genoemd, betreffen: 'Het salaris is onvoldoende' (in totaal $23 \%$ ), 'Er is nauwelijks sprake van professionalisering van leraren' (in totaal $21 \%$ ), 'Er zijn onvoldoende mogelijkheden voor opleiding en training' (in totaal 20\%), 'De werksfeer is niet plezierig' (in totaal $20 \%$ ), 'Ik ben op zoek naar een nieuwe uitdaging binnen het onderwijs' (in totaal 20\%) en 'Ik ben het niet eens met het personeelsbeleid op mijn school' (in totaal 20\%). De verschillen tussen Bonaire enerzijds en Sint Eustatius en Saba anderzijds zijn bij voorgaande redenen veelal beperkt, behalve bij laatstgenoemde reden. Onenigheid over het personeelsbeleid wordt op Bonaire door 22 procent genoemd tegenover 12 procent op Sint Eustatius en Saba.

Onder het cluster 'leefomstandigheden' vinden we de tweede meest genoemde vertrekreden, namelijk 'De kosten van levensonderhoud zijn (te) hoog' (in totaal $37 \%$ ). Ongeveer een vijfde van de respondenten (in totaal 19\%) geeft aan dat ze de onderwijsmogelijkheden en/of -kwaliteit voor hun kinderen onvoldoende vinden. Onder de andere pushfactoren binnen het cluster 'leefomstandigheden' zien we flinke verschillen tussen Bonaire enerzijds en Sint Eustatius en Saba anderzijds. Op laatstgenoemde eilanden wordt veel vaker als vertrekreden genoemd: 'De recreatiemogelijkheden zijn onvoldoende' (26\% versus $11 \%$ op Bonaire), 'De medische voorzieningen zijn onvoldoende' (21\% versus $7 \%)$. Ook geven respondenten Sint Eustatius en Saba iets vaker aan dat ze 'uitgekeken' zijn op het eiland en de sociale controle benauwend vinden. Eerder (Figuur 4.1) zagen we overigens dat een deel van de respondenten de sociale controle juist als prettig ervaart.

Laatstgenoemde verschillen lijken wederom vooral het verschil in schaalgrootte te weerspiegelen tussen Bonaire enerzijds en Sint Eustatius en Saba anderzijds. Ook onder het kopje 'sociaal netwerk' lijkt dit terug te komen: op het relatief kleine Sint Eustatius en Saba wordt bijvoorbeeld vaker aangegeven dat de partner er geen werk kan vinden en/of wil vertrekken.

Tot slot zien we dat er voor een relatief groot aandeel (in totaal 17\%) geen redenen heeft om de huidige baan te verlaten, waarbij dit vooral op Bonaire aangegeven wordt (19\% tegen $10 \%$ op Sint Eustatius en Saba). Uit nadere (regressie)analyse)

25. Voor een totaaloverzicht van de percentages voor alle genoemde pushfactoren, zie Bijlage B: Tabellenboek. 
volgt dat deze verschillen verklaard kunnen worden door het geboorte(ei)land en de leeftijd van de respondentne. Personen die geboren zijn in Caribisch Nederland geven vaker aan geen enkele reden tot vertrek te hebben, evenalspersonen van 40 jaar of ouder. Dat laatste blijkt overigens weer samen te hangen met het feit dat deze leraren ook vaker dan jongeren een vast contract hebben. 
Figuur 4.4 - Veelgenoemde redenen om huidige baan te verlaten, naar eiland, meerdere antwoorden mogelijk $(n=186)$

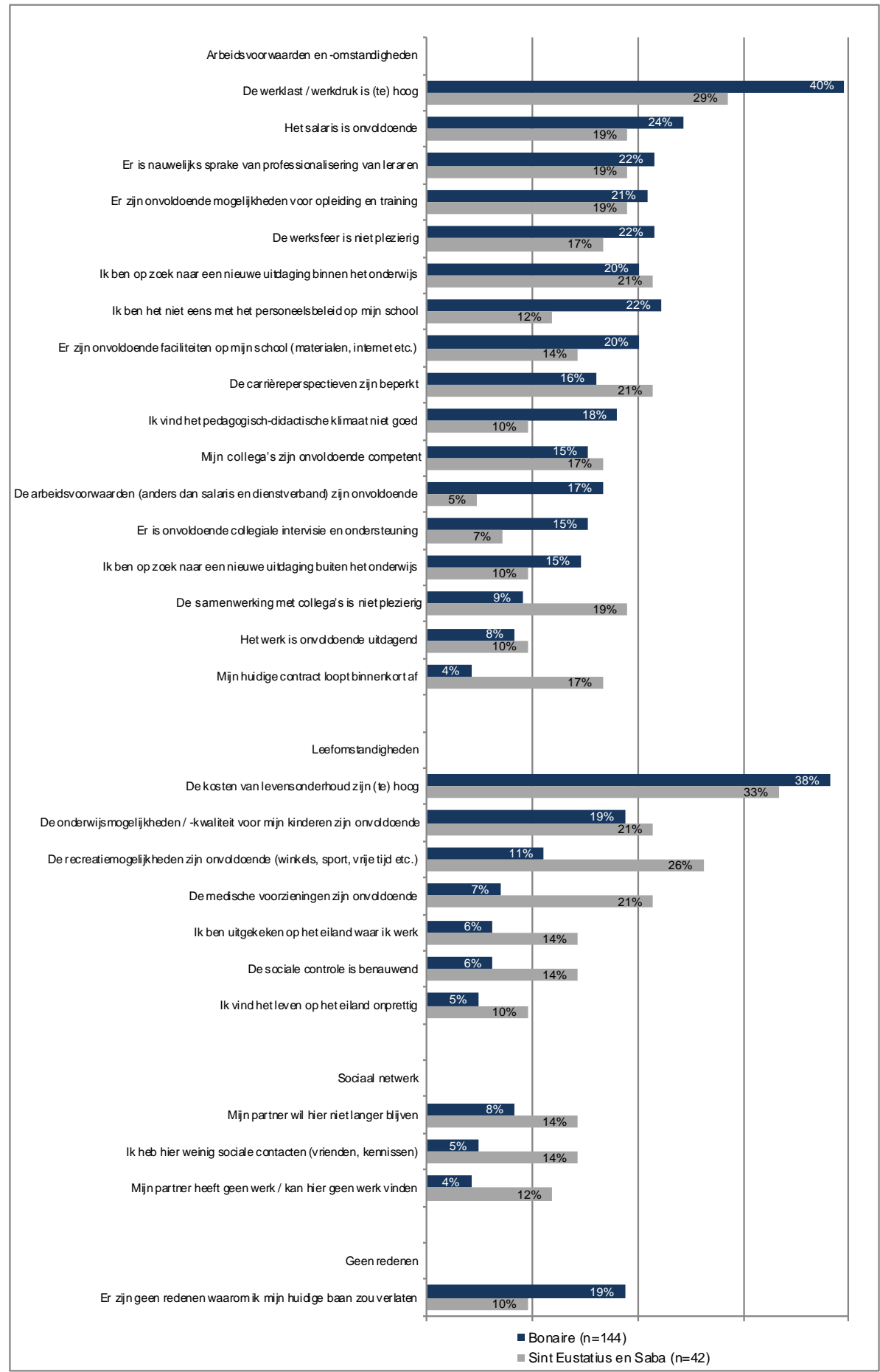

NB: Alleen redenen die door $10 \%$ van respondenten op Bonaire óf Sint Eustatius/Saba zijn genoemd Bron: Enquête lerarenmobiliteit Caribisch Nederland, ROA (2016) 


\subsubsection{Belangrijkste pushfactor vooral werkgerelateerd, specifieke redenen sterk verschillend}

Aan het lesgevende personeel is gevraagd om aan te geven welke van de genoemde redenen voor hen het belangrijkst is om de baan te (willen) verlaten. Wederom blijkt dat er zeer veel verschillende hoofdredenen genoemd worden. De percentages van de meest genoemde categorieën zijn dan ook betrekkelijk laag. ${ }^{26}$ De meest genoemde hoofdreden betreft 'De werklast / werkdruk is (te) hoog' (14\%), gevolgd door 'Het salaris is onvoldoende' (11\%). Alle overige vertrekredenen (allemaal genoemd door minder dan 4\%) vormen tezamen 59 procent van het totaal. Bijna één op de vijf respondenten (17\%) geeft, zoals we eerder reeds zagen, aan dat er voor hen geheel geen reden is om hun baan te verlaten.

Vanwege de grote variatie in de belangrijkste pushfactor, zijn de genoemde hoofredenen in Figuur 4.5 geclusterd in drie categorieën: 'arbeidsvoorwaarden en omstandigheden', 'leefomstandigheden' en 'sociaal netwerk'. Voor de overgrote meerderheid, namelijk drie kwart van de respondenten (73\%), is de belangrijkste vertrekreden werkgerelateerd. Het gaat dan onder meer om onvoldoende salaris, te hoge werkdruk of een onplezierige werksfeer.

Voor 15 procent van de respondenten is de belangrijkste vertrekreden gerelateerd aan de leefomstandigheden, bijvoorbeeld onvoldoende onderwijsmogelijkheden of kansen voor hun kinderen of (hoge) levenskosten. Tot slot geeft 12 procent aan dat de hoofdreden om de baan te (willen) verlaten te maken heeft met het sociaal netwerk, bijvoorbeeld omdat de partner of de kinderen niet langer willen blijven.

26. Een volledig overzicht van de 'belangrijkste pushfactoren' kan gevonden worden in Bijlage B: Tabellenboek. 
Figuur 4.5 - Welke van de genoemde redenen om uw huidige baan te verlaten, is het belangrijkst, 3 clusters $(n=137)$

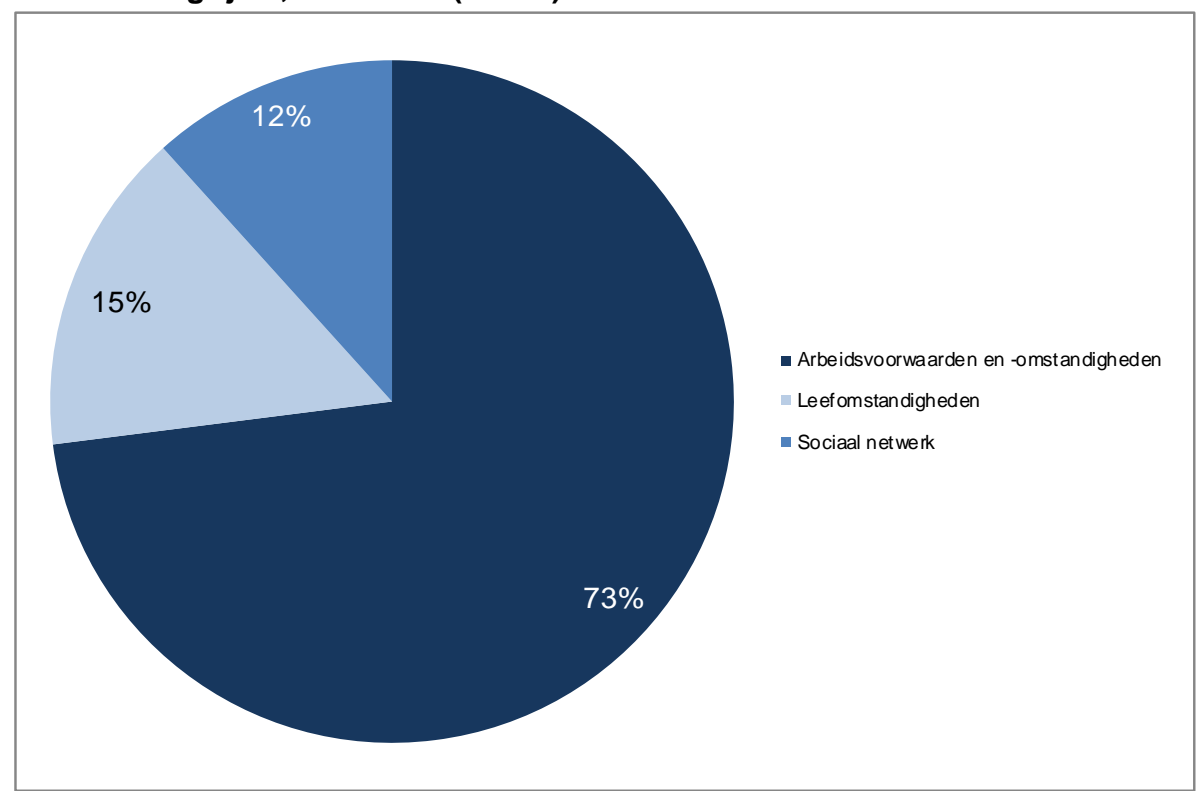

NB: Exclusief 'Er zijn geen redenen waarom ik in mijn huidige baan zou blijven' en open antwoorden Bron: Enquête lerarenmobiliteit Caribisch Nederland, ROA (2016)

Een specificatie van Figuur 4.5 naar het eiland waar men werkzaam is, toont significante verschillen tussen Bonaire enerzijds en Sint Eustatius en Saba anderzijds (Figuur 4.6). Op Bonaire geeft 76 procent aan dat de belangrijkste vertrekreden werkgerelateerd is. Op Sint Eustatius en Saba gaat het om 61 procent. Op laatstgenoemde eilanden wordt relatief vaak een vertrekreden genoemd die met het sociaal netwerk te maken heeft (bijvoorbeeld dat de partner niet wil blijven), namelijk 26 procent versus 8 procent op Bonaire. Het is denkbaar dat deze verschillen te maken hebben met de kleinschaligheid van Sint Eustatius en Saba ten opzichte van Bonaire, waardoor het bijvoorbeeld voor de partner moeilijker werk is om te vinden is of er minder voorzieningen zijn om sociale contacten op te doen (zoals uitgaansgelegenheden). Nadere analyse op de belangrijkste vertrekreden toont geen verdere verschillen naar achtergrondkenmerken (zoals sector, functie of geboorte(ei)land). Vrij opvallend zijn er bij de (belangrijkste) pullfactoren dus wel significante verschillen naar geboorte(ei)land, maar niet wat betreft de belangrijkste pushfactoren. 
Figuur 4.6 - Welke van de genoemde redenen om uw huidige baan te verlaten, is het belangrijkst, 3 clusters, naar eiland $(n=137)$

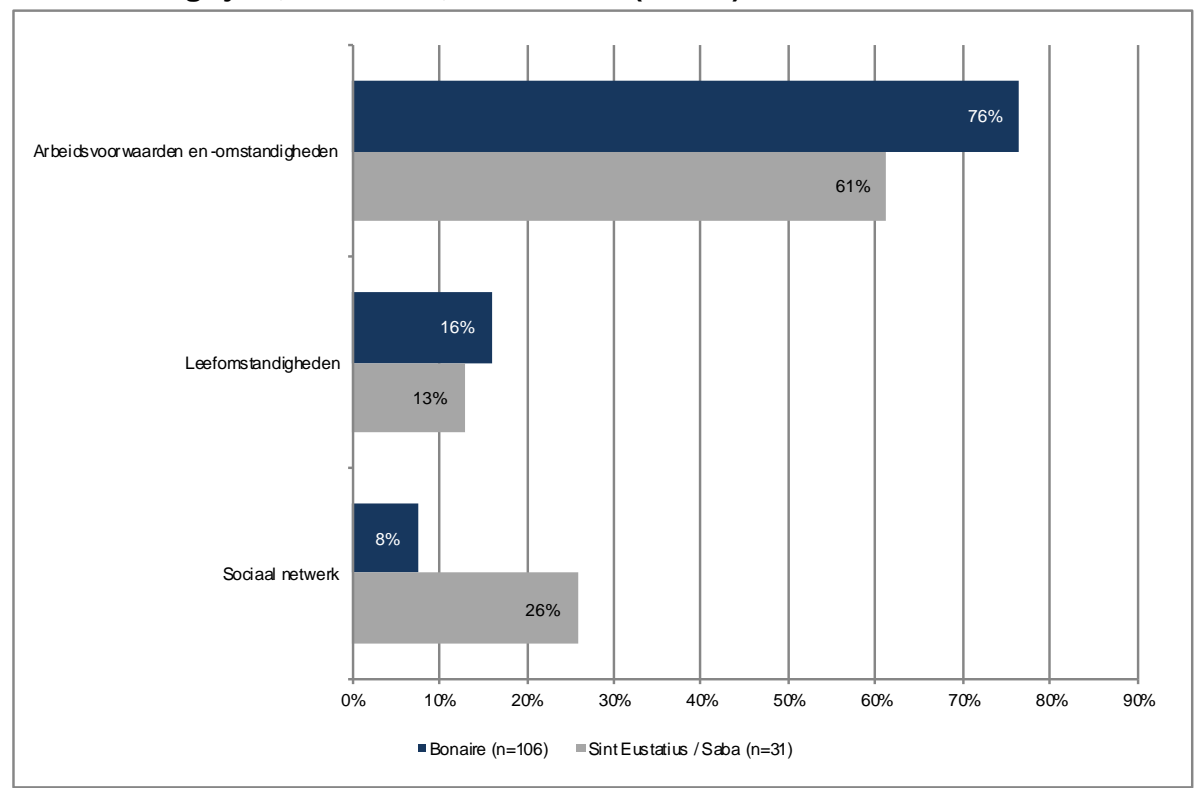

NB: Exclusief 'Er zijn geen redenen waarom ik in mijn huidige baan zou blijven' en open antwoorden Bron: Enquête lerarenmobiliteit Caribisch Nederland, ROA (2016)

\subsection{Toekomstverwachtingen}

\subsubsection{Meer dan helft verwacht binnen vijf jaar huidige baan te verlaten}

De respondenten zijn gevraagd om een inschatting te geven van hoelang zij in hun huidige functie denken te werken, hoelang zij les blijven geven, en hoelang zij in Caribisch Nederland blijven werken. In Figuur 4.7 zijn de resultaten weergegeven. Het betreft hier overigens alleen respondenten die een toekomstinschatting konden maken, ongeveer een vijfde geeft aan het niet te weten.

Ruim de helft van de respondenten (55\%) die een inschatting kunnen maken over hun (nabije) toekomst, verwacht maximaal vijf jaar in de huidige functie te blijven (Figuur 4.7). Drie tiende (29\%) verwacht minder dan twee jaar de huidige functie te bekleden. Een derde van de respondenten (32\%) verwacht juist langdurig in de huidige functie te blijven. Zij geven aan meer dan tien jaar, dan wel tot hun pensioen in hun huidige baan te blijven.

De verwachtingen wat betreft het les geven in het algemeen laten zien dat een forse groep leraren in een andere lesgevende functie in het onderwijs denkt te gaan werken. Immers denkt ongeveer de helft van de respondenten langdurig in het onderwijs les te blijven geven (minimaal tien jaar of tot pensioen), terwijl slechts een derde verwacht dit in de huidige functie (bij de huidige werkgever) te doen. Verder denkt bijna drie op de tien respondenten (28\%) maximaal vijf in het onderwijs jaar les 
te blijven geven (ongeacht waar), een vijfde (20\%) verwacht dit vijf tot tien jaar te doen.

Tot slot kijken we naar de verwachting over het blijven werken in Caribisch Nederland. Ruim een derde van de respondenten (36\%) verwacht hier maximaal vijf jaar te werken, een tiende (11\%) verwacht vijf tot tien jaar in Caribisch Nederland te blijven werken. Ruim de helft (53\%) denkt langer dan tien jaar, dan wel tot het pensioen op één van de drie eilanden te blijven werken. Dit betekent dat er een groter aandeel respondenten is dat kortdurend (bijvoorbeeld maximaal vijf jaar) in Caribisch Nederland denkt te werken, dan het aandeel dat kortdurend les denkt te geven. Dit impliceert dat een deel van de leraren verwacht (c.q. overweegt) om buiten Caribisch Nederland les te gaan geven. Uit de volgende paragraaf zal blijken dat dit vooral betrekking heeft op de leraren die afkomstig zijn van Europees Nederland.

Figuur 4.7 - Hoelang denkt u nog...

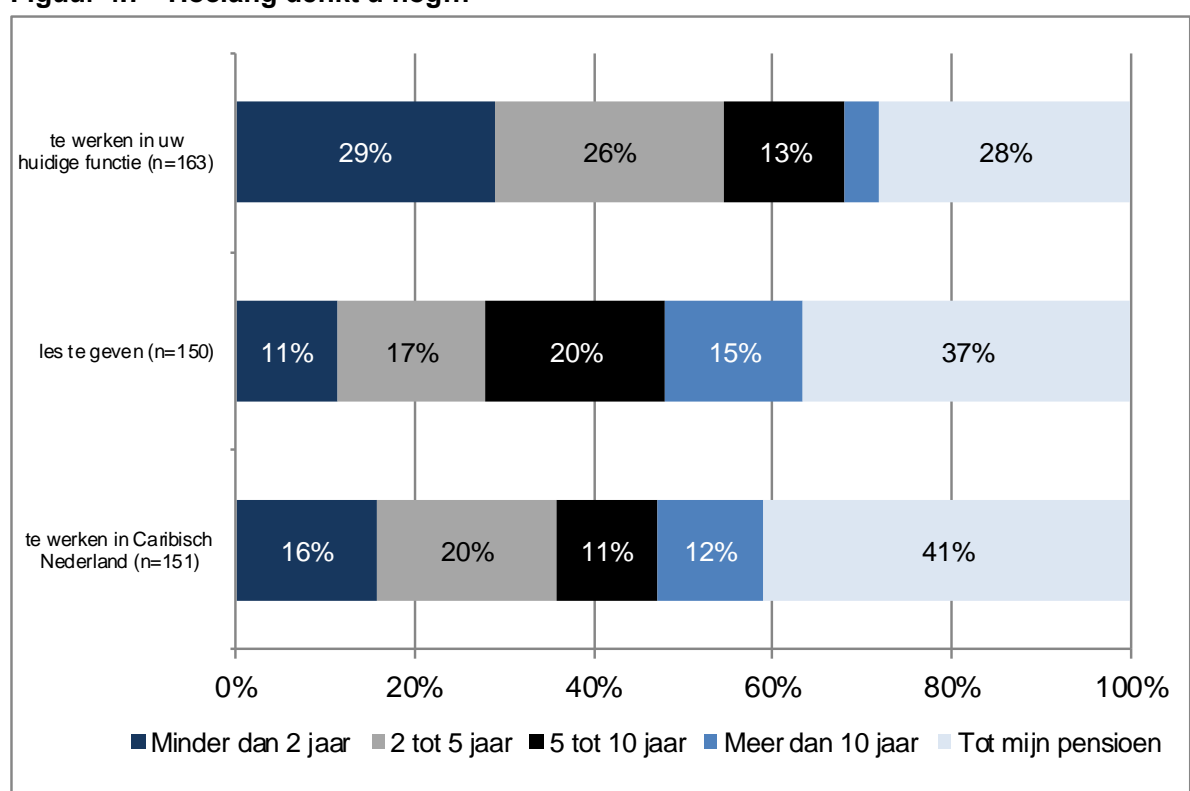

NB: Exclusief 'weet niet'. Het gaat bij het item 'werken in uw huidige functie' om $14 \%$ van de totale responsgroep, bij de andere items betreft het $20 \%$.

Bron: Enquête lerarenmobiliteit Caribisch Nederland, ROA (2016)

\subsubsection{Drie kwart van Europese Nederlanders verwacht binnen vijf jaar huidige baan te verlaten}

In Figuur 4.8, Figuur 4.9 en Figuur 4.10 zijn specificaties van de voorgaande figuur gemaakt naar geboorte(ei)land. De figuren tonen respectievelijk de verwachting over hoelang men verwacht te blijven werken in de huidige functie, in een lesgevende functie, en in een functie in Caribisch Nederland. Lesgevend personeel dat geboren is in Europees Nederland verwacht veelal niet om langdurig in de huidige functie te blijven. Drie kwart van deze groep (74\%) verwacht maximaal vijf jaar in de huidige functie te blijven. Ruim vier op de tien (44\%) verwacht zelfs minder dan twee jaar in 
de huidige baan te werken. Toch zijn er ook Europese Nederlanders die wel lang in hun functie denken te blijven: 14 procent denkt meer dan tien jaar, dan wel tot het pensioen in de huidige baan te blijven.

Vergeleken met de verwachtingen van Caribische Nederlanders zijn de verschillen enorm. In totaal verwacht 28 procent van hen maximaal vijf jaar in de functie te blijven en denkt slechts 7 procent minder dan twee jaar de huidige functie uit te oefenen. Meer dan zes op de tien (62\%) verwacht meer dan tien jaar, dan wel tot het pensioen in de huidige baan te blijven.

Van de personen die elders geboren zijn (i.e. noch in Europees Nederland, noch in Caribisch Nederland) verwacht 44 procent maximaal vijf jaar in de huidige functie te blijven. Zij hebben dus veel vaker dan Caribische Nederlanders de verwachting kort in de functie te blijven, maar ten opzichte van Europese Nederlanders verwachten ze juist langer te werkzaam te zijn in hun functie.

Uit regressieanalyse volgt dat verschillen in verwachtingen naar geboorte(ei)land blijven bestaan wanneer rekening gehouden wordt met kenmerken als het eiland waar men werkzaam is, de onderwijssector, het type functie, de leeftijd en het geslacht. Van deze kenmerken blijkt alleen het geslacht significant van invloed op de verwachting om kort in de huidige functie te blijven werken. Vrouwen verwachten vaker binnen vijf jaar de baan te verlaten. Uit aanvullende analyse blijkt verder dat respondenten met een vast dienstverband (niet verrassend) langer in de huidige functie denken te werken. Ze verwachten echter niet langer les te geven in het algemeen of te werken in Caribisch Nederland.

Figuur 4.8 - Hoe lang denkt $u$ nog te werken in uw huidige functie, naar geboorte(ei)land

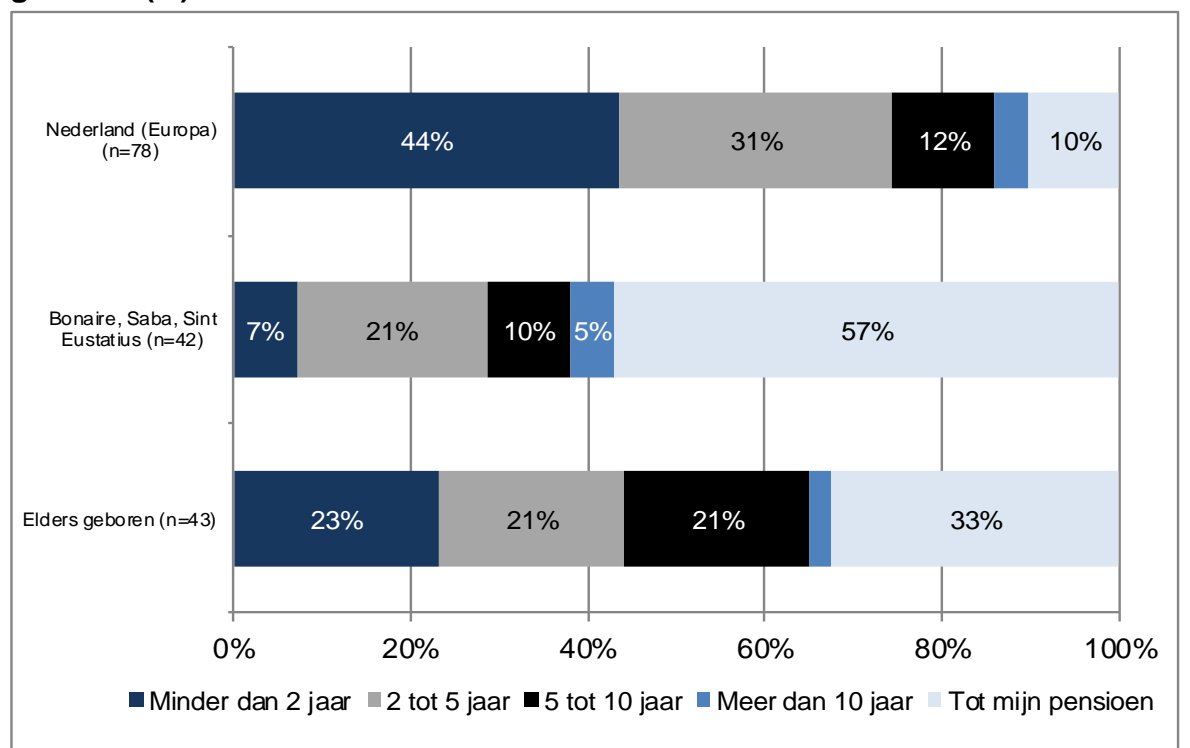

NB: Exclusief 'weet niet'. De groep 'weet niet' vormt 14 procent van de totale responsgroep. Bron: Enquête lerarenmobiliteit Caribisch Nederland, ROA (2016) 
Ook als het gaat om de toekomstverwachtingen over het les blijven geven in algemene zin (niet noodzakelijk in de huidige functie), zijn er forse verschillen tussen personen die geboren zijn in Caribisch Nederland en de rest. Waar Europese Nederlanders in 36 procent van de gevallen verwachten maximaal vijf jaar les te geven, gaat het bij Caribische Nederlanders om slechts 12 procent.

Drie kwart van de personen die geboren zijn op Bonaire, Sint Eustatius en Saba (75\%) verwachten meer dan tien jaar, dan wel tot hun pensioen les te blijven geven. Onder Europese Nederlanders gaat het om 43 procent en bij personen die elders geboren zijn om 47 procent. Wederom volgt uit de regressieanalyse dat verschillen naar geboorte(ei)land blijven bestaan, wanneer gecorrigeerd wordt voor achtergrondkenmerken (geen van de kenmerken zijn significant van invloed).

\section{Figuur 4.9 - Hoe lang denkt u nog les te geven, naar geboorte(ei)land}

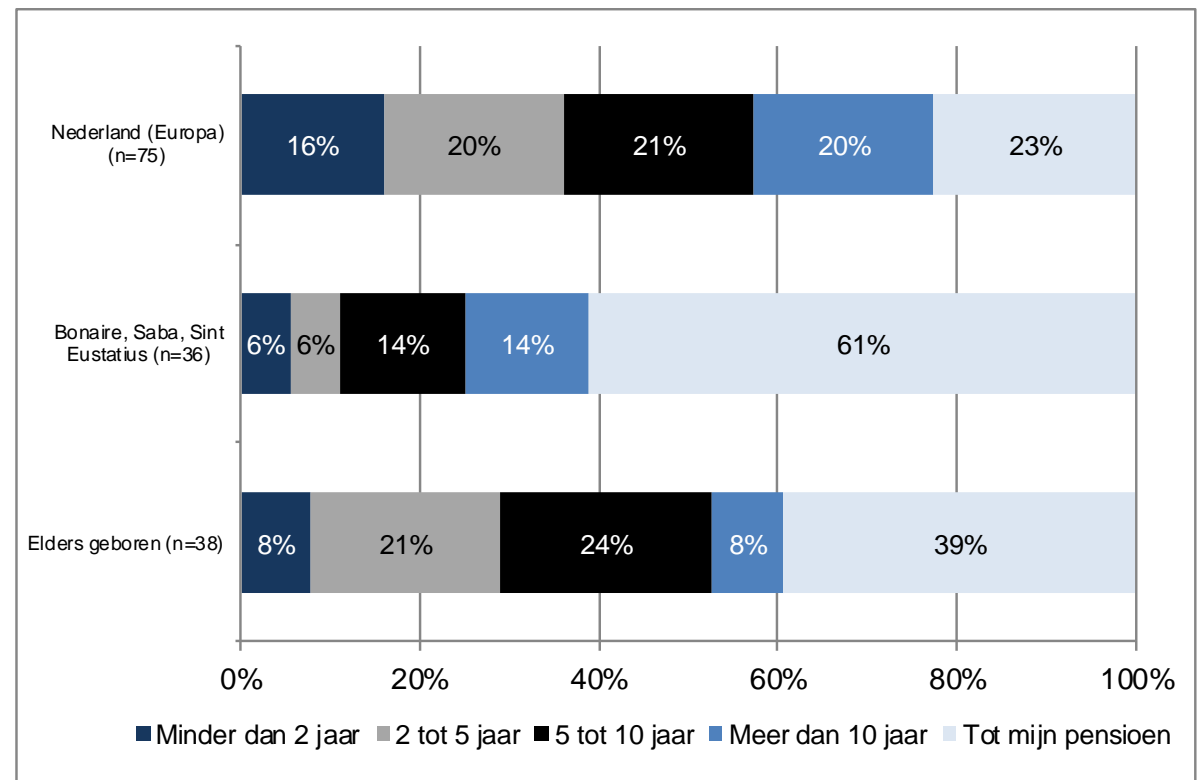

NB: Exclusief 'weet niet'. De groep 'weet niet' vormt 20 procent van de totale responsgroep.

Bron: Enquête lerarenmobiliteit Caribisch Nederland, ROA (2016)

Ten slotte gaan we in op de toekomstverwachtingen om in Caribisch Nederland te blijven werken. Figuur 4.10 laat wederom grote verschillen naar geboorte(ei)land zien. Waar 59 procent van de Europese Nederlanders verwacht maximaal vijf jaar in Caribisch Nederland te blijven werken, ligt het percentage onder personen die op Bonaire, Sint Eustatius of Saba zijn geboren slechts op 10 procent. Bij personen die elders zijn geboren gaat het om 22 procent.

Onder Caribische Nederlanders geeft 85 procent aan meer dan tien jaar, dan wel tot het pensioen in Caribisch Nederland te blijven werken. Onder Europese Nederlanders betreft het slechts 27 procent. Slechts een kleine groep van de Europese Nederlanders verwacht dus tot het einde van de loopbaan te verblijven in Caribisch Nederland. Verschillen naar geboorte(ei)land blijven wederom zichtbaar na 
correctie voor achtergrondkenmerken in regressieanalyse. Geen van de kenmerken blijken significant van invloed op de verwachtingen om kort/lang in Caribisch Nederland te blijven werken, met uitzondering van de onderwijssector waarin men werkt. Respondenten uit het vo/mbo verwachten iets vaker dan respondenten uit het dat zij kortdurend in Caribisch Nederland zullen werken.

Figuur 4.10 - Hoe lang denkt u nog te werken in Caribisch Nederland, naar geboorte(ei)land

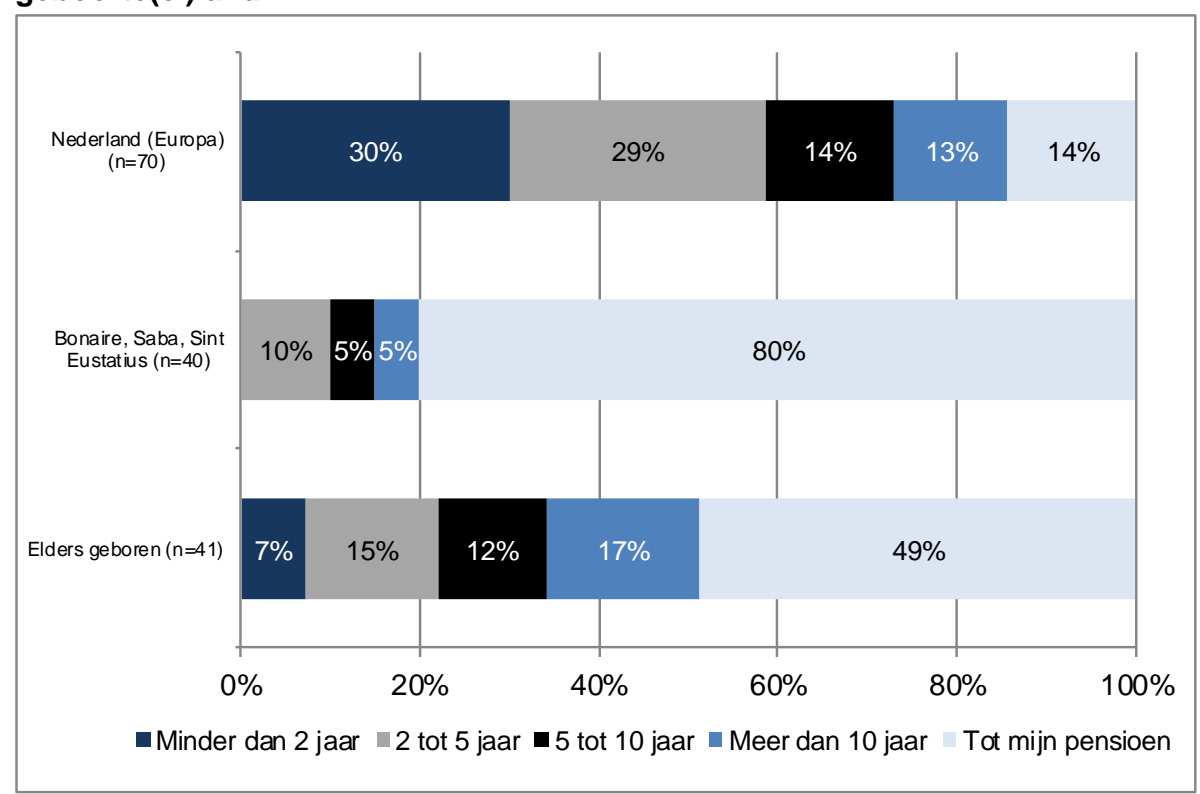

NB: Exclusief 'weet niet'. De groep 'weet niet' vormt 20 procent van de totale responsgroep. Bron: Enquête lerarenmobiliteit Caribisch Nederland, ROA (2016) 


\section{Nadere duiding van pull- en pushfactoren: kwalitatieve bevindingen}

In het kader van het voorliggende onderzoek over het hoge verloop op de lerarenmarkt in Caribisch Nederland zijn er interviews gehouden met een diverse groep van personen, welke is opgenomen in Bijlage C. De gesprekspartners bestonden uit schoolleiders en leraren van de scholen op Bonaire, Sint Eustatius en Saba, aangevuld met staf- en beleidsmedewerkers van diverse instellingen in Caribisch en Europees Nederland. Deze groep vormt een goede afspiegeling van de relevante stakeholders van het onderwijs in Caribisch Nederland. Alleen uitkomsten die van meerdere kanten werden bevestigd zijn gebruikt voor dit rapport.

Op veel scholen wordt erkend dat het verloop hoog is. Onder enkele scholen wordt dit niet als een probleem ervaren, vooral daar waar meer leraren van het eiland zelf kunnen worden geworven. Vooral onder Europese Nederlanders is er een groot verloop. Een hoog verloop betekent dat er elk jaar een nieuw team met veel nieuwe leraren moet worden samengesteld, wat niet gewenst is voor de zittende leraren, het management en de leerlingen. Schoolleiders en HRM-medewerkers geven aan vaak moeite te hebben om de vacatures naar tevredenheid in te vullen. Het komt te vaak voor dat het aantal geschikte kandidaten gering is, waardoor er weinig keuze overblijft. Door het hoge verloop en de moeizame werving van geschikte kandidaten is de continuïteit van het onderwijs niet gewaarborgd en kan de onderwijskwaliteit in gevaar komen.

De bevindingen in dit hoofdstuk zijn bedoeld ter illustratie, bevestiging en nadere duiding van de kwantitatieve gegevens uit dit rapport rondom de push- en pullfactoren. Hieronder komen achtereenvolgens aan de orde de werving, de arbeidsvoorwaarden, de eilandcultuur en de schoolcultuur en het HRM-beleid. Alle factoren die met deze onderdelen samenhangen kunnen invloed uitoefenen op het aantrekken en het verloop van leraren, en daardoor als pull- of pushfactor direct of indirect van belang zijn.

\subsection{Werving: duidelijke informatie belangrijk, moeizame zoektocht naar geschikt personeel}

Duidelijke informatie bij de werving van leraren over wat verwacht mag worden van het lesgeven in Caribisch Nederland, wordt over het algemeen van groot belang gevonden. Uit de enquêtegegevens blijkt dat de informatieverstrekking over de leefomstandigheden laag scoort onder Europese Nederlanders en degenen die buiten Nederland geboren zijn. Aspecten die volgens de gesprekspartners van belang zijn, betreffen het vermijden van een verkeerde beeldvorming, het op een juiste wijze weergeven van de cultuur op het eiland en van de implicaties van de kleinschaligheid en - vooral op Saba en Sint Eustatius - het informeren over het ontbreken van een uitgaansleven en van recreatieve voorzieningen. Bovendien bestaat er een risico op heimwee naar familie en vrienden op grote afstand waar op zou moeten worden gewezen. De informatievoorziening over de 
werkomstandigheden wordt in de enquête nog slechter beoordeeld dan over de leefomstandigheden. Het gaat dan onder meer over de arbeidsvoorwaarden, de schoolcultuur en de onderwijscontext. Sommige leraren geven in de gesprekken aan dat de voorlichting over de leef- en werkomstandigheden achteraf gezien wat te positief was, en dat essentiële informatie soms lijkt te ontbreken. Anderen menen echter dat een te negatieve beeldvorming in de werving over het werken in Caribisch Nederland kwetsend kan zijn voor de lokale bevolking.

Bij de werving valt het op dat alle scholen op eigen wijze en meestal onafhankelijk van elkaar personeel werven. Voor Europese Nederlanders wordt er vaak geworven via meesterbaan.nl of indeed.nl. Voor Caribische Nederlanders en Engelstaligen in het Caribisch gebied worden er advertenties geplaatst in Caribische kranten. Dit laatste is met name voor Sint Eustatius en Saba van belang, omdat het onderwijs daar Engelstalig is. Bovendien worden/zijn de eindtermen van het voortgezet onderwijs ingericht volgens de richtlijnen van het Caribbean Examinations Council (CXC), waar veel onderwijssystemen van landen in het Caribisch gebied bij zijn aangesloten (o.a. ook Sint Maarten en Suriname). Het vak Nederlands wordt op Saba en Sint Eustatius derhalve nu gegeven als vreemde taal. ${ }^{27}$ Dat betekent naar verwachting dat er in de toekomst vooral behoefte is aan leraren en afgestudeerden uit het Engelstalige Caribisch gebied of Noord-Amerika (bijvoorbeeld Canada) in plaats van uit Europees Nederland of Curaçao, Bonaire en Aruba.

Sommige scholen voeren Skype-gesprekken met de geselecteerde kandidaten, andere scholen gaan zelfs naar Nederland om in de klas te kijken hoe de betreffende kandidaten lesgeven. Een eventuele proefweek van lesgeven door de kandidaten en kennismaking op de eilanden zelf wordt als duur en weinig zinvol ervaren. Sommige scholen schakelen wervingsbureaus in, maar de ervaringen hiermee zijn wisselend. Sommige scholen hebben het liefst pas afgestudeerden, die bij voorkeur niet gebonden zijn aan een partner of gezin. Ze zijn niet alleen flexibeler, maar ook is het ambitieniveau van meer ervaren leraren nog wel eens te hoog. Bovendien kunnen de partners of de gezinsleden van de aangestelde leraar niet altijd aarden. Andere scholen proberen juist de leraren te werven die in Caribisch Nederland terecht zijn gekomen of een band met de eilanden hebben vanwege het werk of de studie van hun partner. In een aantal gevallen wordt er gebruik gemaakt van onderwijsassistenten, die soms in opleiding zijn als leraar. Via de LOFO van de Universiteit van Curaçao op Bonaire wordt getracht onderwijsassistenten van het eiland zelf op te leiden. Helaas zijn er niet elk jaar voldoende aanmeldingen om de minimumgrens (van 15 à 20) die hiervoor staat te halen om een cohort te starten. Sommigen bepleiten echter een kwalitatief goede lerarenopleiding vanuit Nederland te starten met een dependance in Caribisch Nederland.

Er zijn verder bedenkingen bij de lange procedures van de Immigratie en Naturalisatiedienst (IND), een punt dat ook in de gehouden enquête naar voren komt. Daardoor komt het voor dat leraren worden aangesteld voor het begin van het

27. De Europees Nederlandse exameneisen bestaan alleen nog op Sint Eustatius voor de oudere lichtingen van leerlingen (hogere klassen), die geleidelijk aan worden uitgefaseerd. 
schooljaar, maar geen les kunnen geven omdat zij nog geen verblijfsvergunning hebben gekregen van de IND. Verder zijn er ook problemen met de erkenning van de diploma's van Surinaamse leraren. De denominatie van scholen lijkt over het algemeen overigens weinig belemmeringen op te leveren bij de werving.

\subsection{Arbeidsvoorwaarden: veel tijdelijke contracten, salaris valt tegen}

Er worden tijdelijke contracten van verschillende termijnen aangeboden aan recent afgestudeerden en meer ervaren leraren die voor het eerst in het Caribisch Nederlandse onderwijs aan het werk gaan. Veel voorkomend is nog altijd een tijdelijk contract van drie jaar met vergoedingen voor de oversteek (heen en terug) en de inrichting van de woning, evenals de zorg voor de oversteek van huisdieren en een overbruggingsvergoeding voor snelle huisvesting op het eiland. Daarnaast wordt er hulp aangeboden bij het zoeken van een woning. De oversteek- en repatriëringskosten worden slechts gedeeltelijk (naar rato van de uitgediende termijn) vergoed als men het tijdelijke contract niet uitdient, wat nogal eens voorkomt. $\mathrm{Na}$ afloop van de termijn wordt een groot deel van de contracten niet verlengd. Een deel van de leraren (op sommige scholen 40\%) krijgt een contract voor onbepaalde tijd, soms wordt het contract eerst nog verlengd voor de duur van in totaal vijf jaar. Ook worden er veel andere tijdelijke contracten aangeboden. Contracten voor de termijn van één jaar zonder oversteekvergoedingen zijn geen uitzondering. Vaak wordt er dan een verlenging tot drie jaar gegeven (dus 1+2 jaar), maar soms een nieuw contract voor één jaar. Bij aanvang van het tijdelijke contract is een contract voor onbepaalde tijd vaak een serieus vooruitzicht. Of dit contract wordt gegeven lijkt vooral af te hangen van het functioneren van de leraar, of het eiland en de school voor de leraar zelf voldoende bevallen voor een langer verblijf, en of er een goede verstandhouding is met de lerarenstaf en het management. Een vast contract is volgens de enquêtegegevens wel één van de belangrijkste redenen om in de baan te blijven, vooral onder de autochtone bevolking van Caribisch Nederland.

De arbeidsvoorwaarden kunnen nogal verschillen tussen en zelfs binnen scholen. Op sommige scholen bestaat er nu beleid om meer consistentie tussen de arbeidsvoorwaarden van verschillende leraren aan te brengen wat betreft salaris, vergoedingen voor overwerk, voor repatriëring, voor jaarlijks bezoek aan Nederland et cetera. De kosten van levensonderhoud worden als hoog ervaren, in overeenstemming met de enquêtegegevens. Het gaat dan om levensmiddelen, om de huur van woningen, en om de ticketprijzen voor vliegreizen naar andere eilanden in de regio. Het lage salaris dat daartegen over staat wordt in de enquêtegegevens als een van de meest genoemde en belangrijkste redenen genoemd om de huidige baan te verlaten. Koopwoningen zijn wel goedkoper dan in Europees Nederland, ook wordt er minder belasting betaald en is de benzineprijs lager dan in Europees Nederland. Het salaris in het voortgezet onderwijs (vo) ligt hoger dan in het primair onderwijs (po), wat wel eens als onrechtvaardig wordt beschouwd door leraren in het po. Bovendien heeft men de indruk dat functies van gelijk niveau bij ministeries (bijvoorbeeld RCN), bij de politie en in het ziekenhuis beter betaald worden. De lerarensalarissen zouden wel hoger liggen dan op veel andere eilanden in het Caribisch gebied. Tot slot wordt aangegeven dat er diverse problemen zijn met de 
inschrijving, de afdracht en de opbouw bij het Pensioenfonds Caribisch Nederland (PCN).

\subsection{Eilandcultuur: professioneel klimaat en opvoeding in het gedrang}

Er wordt gesproken over de kleinschaligheid op de eilanden die gepaard gaat met diverse problemen. Enkelen noemen de beperkte beschikbaarheid van mensen die goed kunnen managen op de eilanden (beperkte bestuurscapaciteit). In een kleine gemeenschap komt men elkaar op meerdere manieren gemakkelijk tegen, niet alleen zakelijk maar ook privé. Er wordt gesproken over een 'roddelcultuur', tegelijkertijd is er ook de vrees om vrijuit en openhartig te kunnen communiceren. 'Vriendjespolitiek' bij aanstellingen, ook binnen scholen, wordt genoemd als een belemmerende factor voor een professioneel werkklimaat. Als het gaat om de omgang tussen groepen van verschillende herkomst wordt er soms discriminatie ervaren. Ook in de open antwoorden in de enquête komt dit naar voren als factor waar men graag vooraf beter over geïnformeerd was geweest. Volgens autochtone leraren trekken Europese Nederlanders elkaar voor, terwijl Europese Nederlanders van mening zijn dat het moeilijk is om te integreren waarbij ze zich eveneens gediscrimineerd voelen. Er bestaat her en der onrust in de schoolorganisatie, veelal gepaard gaand met een schoolmanagement dat als ongeschikt wordt ervaren. Bovendien zijn er veel wisselingen van de wacht in het management. Daardoor worden soms eerder genomen beslissingen teruggedraaid, wat de onrust vergroot en onduidelijkheid schept. Een onplezierige werksfeer en onvrede over het personeelsbeleid op school zijn door leraren veelgenoemde redenen om de huidige baan te verlaten.

Een klein deel van de gesprekspartners schetst een zeer somber beeld. Zo zijn er veel leerlingen met problemen thuis en lijkt er sprake van toenemende criminaliteit en drugsgebruik op de eilanden. Er wordt agressiviteit, een gebrek aan respect van leerlingen en verharding op school gesignaleerd. Dit brengt risico's voor de veiligheid voor leraren en leerlingen met zich mee. Ouders zijn daarbij voor leraren soms moeilijk bereikbaar en er is veel voortijdige schooluitval. In algemene zin zijn er nogal wat gesloten gemeenschappen op de eilanden (bijvoorbeeld religieuze groeperingen of gesloten families), en kunnen onderling wantrouwen en negativiteit groot zijn. Hierdoor kan het veiligheidsgevoel in het gedrang komen. Sommige gesprekspartners signaleren de armoede onder gezinnen, en spreken hun zorgen uit over de opvoeding van kinderen en het gebruik van geweld. Er wordt genoemd dat opvoeden nog wel eens door de grootouders gebeurt, er veel eenouder- en samengestelde gezinnen zijn alsmede leerlingen met hechtingsproblemen. Ook wordt gesproken over weinig structuur voor kinderen en een gebrek aan waarden en normen.

\subsection{Schoolcultuur en HRM-beleid: hoge werkdruk, cultuurkloof, gebrekkige ondersteuning en nauwelijks talentbeleid}

Het werken in het onderwijs wordt als 'anders' en meestal zwaarder ervaren dan in Europees Nederland. Leraren krijgen te maken met achterstandsleerlingen met sociale problemen, grote gezinsproblematiek en emotionele stoornissen. Ook is de manier van lesgeven anders. De werkdruk wordt mede hierdoor vaak als hoog 
ervaren. Uit de enquête komt de hoge werkdruk inderdaad als meest genoemde en belangrijkste factor naar voren om de huidige baan te verlaten. Er zijn op school wel maatschappelijk werkers (EOZ) en IB'ers aan de slag. De traditionele manier van lesgeven in Caribisch Nederland komt op Europese Nederlanders vaak nogal autoritair over. Het pedagogisch-didactisch concept dat gehanteerd wordt sluit niet altijd aan bij de ideeën en opleiding van Europese Nederlanders. Het is in de enquête één van de meer genoemde vertrekfactoren voor leraren. Het lage niveau van het onderwijs en de gebrekkige taalbeheersing van de leerlingen worden eveneens meermaals genoemd in de enquête. Het Papiamento is bovendien een taal waarin meer in de gebiedende wijs wordt gesproken, hetgeen de handelswijze en het begrip van leraren uit Europees Nederland bemoeilijkt. Er zijn bijvoorbeeld cultuurverschillen in aanspreekvorm, in kleding (denk ook aan schooluniformen op Caribisch Nederland), en in straffen in plaats van belonen.

De faciliteiten en de organisatie op school laat nogal eens te wensen over wat betreft materialen, kopieerfaciliteiten, logistiek en inkoop, en er is veel bureaucratie rondom bestellingen. Dit komt eveneens uit de enquêtegegevens naar voren. Toch is hier ook verbetering waarneembaar, deels omdat scholen nu zelf budgetverantwoordelijk zijn geworden, en deels omdat er de laatste jaren veel geïnvesteerd is in nieuwe gebouwen en voorzieningen als beamers, laptops en airconditioning. Op Sint Eustatius maakt men zich echter zorgen over de transitie naar CXC: men is bevreesd dat de kennis bij de leraren en de noodzakelijke materialen voor diverse vakken zullen ontbreken.

Er zou meer aandacht moeten zijn voor op maat gesneden professionalisering. Een gebrekkige professionalisering van leraren, in combinatie met weinig mogelijkheden voor opleiding en training, een beperkt carrièreperspectief en een weinig plezierige samenwerking met collega's die vaak incompetent geacht worden, zijn immers veelgenoemde vertrekredenen uit de enquête. Verder zou het verloop tegen kunnen worden gegaan door perspectieven te bieden en door onrust en onduidelijkheden over contracten en contractverlengingen weg te nemen. Ook dit wordt overigens bij de gebrekkige informatievoorziening in de enquête genoemd. Voor sommige leraren zou doorstroom naar hogere functies mogelijk moeten zijn, hoewel hiervoor de mogelijkheden voor met name Saba en Sint Eustatius beperkt zijn. Er worden door de leraren weliswaar veel opleidingen en cursussen gevolgd (onder andere via de Lerarenbeurs), maar er is geen talentbeleid. Het vasthouden of ontwikkelen van personeel (ondanks het bijhouden van persoonlijke ontwikkelingsplannen) speelt een te geringe rol. Er zou meer aandacht kunnen worden besteed aan samenwerking tussen scholen, ook tussen de verschillende eilanden, wat betreft de doorstroom van leraren. Men maakt zich zorgen over de afloop van de regeling voor de extra gelden die de Caribisch Nederlandse scholen konden benutten tot juli 2016 (de bekwaamheidsgelden). Goede leraren blijven volgens de gesprekpartners van groot belang, waarbij werkplezier, veiligheid, een open leercultuur en onderlinge feedback van belang is.

De taakomschrijvingen zijn soms onduidelijk, en men werkt te weinig vanuit de passie. Er is weinig vertrouwen tussen professionals, binnen een politieke in plaats 
van een professionele cultuur. Jonge leraren kunnen gemakkelijk geconfronteerd worden met ordeproblemen. Volgens enkele geïnterviewden hangt dit samen met hun geringe ervaring in het werken met (achterstands)leerlingen, en kan het worden verergerd door de cultuurkloof tussen allochtone (inclusief Europees Nederlandse) leraren en hun leerlingen. De culturele mix in het lerarenteam is in potentie interessant, in de praktijk blijkt echter de integratie tussen leraren van verschillende herkomstlanden soms moeilijk te gaan, en is er polarisatie en onvoldoende vertrouwen in het schoolmanagement. Ook veelvuldige wisselingen van teamleiders en directeuren met telkens nieuwe veranderingen of het terugdraaien van eerder genomen besluiten, helpen daar niet bij,. $\mathrm{Er}$ is een goede planning met tijdig opgestelde formatieplannen nodig, maar tevens dienen er eenduidige maatstaven gebruikt te worden in het HRM-beleid. Multiculturele activiteiten en 'social events' zouden een meerwaarde kunnen creëren voor een goede werksfeer. Helaas mislukken nieuwe initiatieven nogal eens. 


\section{Conclusies en aanbevelingen}

Het ministerie van Onderwijs, Cultuur en Wetenschap (OCW) streeft naar een duurzame en bevoegde formatie van leraren in Caribisch Nederland die bekwaam en betrokken is, vertrouwd is met lokale omstandigheden en cultuur, en die ook voor langere tijd werkzaam willen zijn in het onderwijs. Uit de voorstudie van Cörvers, Claessen en Kluijfhout (2015) volgt echter dat er een grote geografische mobiliteit is op de Caribisch Nederlandse lerarenmarkt. De herkomst van de leraren op Bonaire, Sint Eustatius en Saba is divers en de uitstroom uit het lerarenberoep is hoog. Dat resulteert in een hoge uitstroom van gemiddeld jaarlijks bijna 15 procent en derhalve een hoge vervangingsvraag.

Op veel scholen wordt erkend dat het verloop hoog is. Onder enkele scholen wordt dit niet als een probleem ervaren, vooral daar waar meer leraren van het eiland zelf kunnen worden geworven. Vooral onder Europese Nederlanders is er een groot verloop. Een hoog verloop betekent dat er elk jaar een team met veel nieuwe leraren moeten worden samengesteld, wat niet gewenst is voor de zittende leraren, het management en de leerlingen. Schoolleiders en HRM-medewerkers geven aan vaak moeite te hebben om de vacatures naar tevredenheid in te vullen. Het komt te vaak voor dat het aantal geschikte kandidaten gering is, waardoor er weinig keuze overblijft. Door het hoge verloop en de moeizame werving van geschikte kandidaten is de continuïteit van het onderwijs niet gewaarborgd en kan de onderwijskwaliteit in gevaar komen.

Deze hoge mobiliteit en de daarmee gepaard gaande belemmeringen voor de opbouw van een stabiel lerarenbestand, vraagt om meer inzicht in de pull- en pushfactoren van lesgevend personeel. Wat maakt het les geven in Caribisch Nederland aantrekkelijk, wat maakt het onaantrekkelijk en hoe kan dit laatste verbeterd worden? Om hier meer inzicht in te verwerven is een vragenlijst ontwikkeld op basis van informatie uit interviews en gesprekken met schoolleiders, staf- en beleidsmedewerkers van onderwijsinstellingen en ministeries in Caribisch en Europees Nederland, aangevuld met kennis uit de wetenschappelijke literatuur. In de voorgaande hoofdstukken zijn de resultaten uit de enquête uitvoerig toegelicht, waarbij ook aandacht is geschonken aan de gevoerde interviews en gesprekken. In dit slothoofdstuk worden de belangrijkste bevindingen nog eens op een rij gezet, en doen we aan de hand van de opgedane kennis enkele beleidsaanbevelingen.

\section{1 (Her)komst en voorbereiding}

De herkomst van het lesgevend personeel in Caribisch Nederland is divers. Dat volgt niet alleen uit de grote variatie in geboorte(ei)landen (onder meer Europees Nederland, Bonaire, Curaçao en Suriname), maar zeker ook uit de 'routes' die men doorlopen heeft alvorens in Caribisch Nederland les te geven. Een zeer groot deel van het lesgevend personeel bestaat (derhalve) uit immigranten en remigranten, waarbij de meesten verhuisd zijn naar Caribisch Nederland om te komen werken. Ook onder remigranten is verhuizen voor werk een veelgenoemde reden, maar voor 
hen is het terug willen keren naar het eiland waar men is geboren of opgegroeid vaak een belangrijke additionele factor. Caribische Nederlanders geven daarbij vaak als belangrijkste motief aan dat ze bij willen dragen aan de (onderwijs)ontwikkeling van het herkomsteiland. Niet-Caribische Nederlanders geven vooral aan dat ze op het eiland zijn komen werken, omdat ze 'iets anders' in het leven wilden en het Caribische, avontuurlijke leven hen aantrok. De intrinsieke motivatie om in Caribisch Nederland te (komen) werken lijkt dus sterk te verschillen naar herkomst(ei)land.

De (terug)komst naar Caribisch Nederland gaat niet altijd 'over rozen'. Men lijkt vaak (enigszins) verrast te zijn door de omstandigheden die men aantreft. Zo had de helft van de respondenten die gemigreerd zijn om te komen werken in Caribisch Nederland, meer informatie over de leef- en werkomstandigheden willen hebben. Uit de interviews is gebleken dat er vaak sprake is van een verkeerde beeldvorming over de eilandcultuur, de kleinschaligheid en het ontbreken van allerlei voorzieningen (dat laatste vooral op Saba en Sint Eustatius). De informatievoorziening over de werkomstandigheden wordt in de enquête nog slechter beoordeeld dan over de leefomstandigheden. Het gaat dan onder meer over de arbeidsvoorwaarden, de schoolcultuur en de onderwijscontext. De voorlichting over de leef- en werkomstandigheden schetst nogal eens een te positief beeld, waarbij essentiële informatie soms lijkt te ontbreken. De behoefte aan meer en betere voorlichting is weliswaar sterker onder migranten die niet (van geboorte) Caribisch Nederlander zijn, maar zelfs onder de Caribische Nederlanders had ongeveer een derde meer informatie willen krijgen. De voorlichting over het Caribische leven en het onderwijs voorafgaand aan migratie lijkt dan ook voor verbetering vatbaar.

Wat betreft de leefomstandigheden had men vooral meer voorlichting willen hebben over de economische situatie (zoals de hoge woonkosten, de beschikbaarheid van woningen, en de armoede op het eiland), over de culturele context (zoals de soms moeizame omgang tussen 'locals' en immigranten en de gebruiken op het eiland), over de immigratieprocedure (de administratieve uitdagingen) en over het klimaat (orkanen en hoge temperaturen). Wat betreft de werkomstandigheden had men vooral meer voorlichting gewenst over de arbeidsvoorwaarden (zoals de salarissen, pensioenvoorzieningen, werktijden en contracten), de culturele (school)context (zoals de omgang met leerlingen en collega's; en de afspraken en bureaucratie op school), en de onderwijscontext (zoals de aanwezige voorzieningen op school, de taalbeheersing van leerlingen en het niveau van het onderwijs).

De behoefte van vooral niet-Caribische Nederlanders aan betere voorlichting en de confrontatie van deze groep met een situatie waar men onvoldoende op geanticipeerd had, kan een mogelijke verklaring zijn voor de lagere baantevredenheid onder de niet-Caribische Nederlanders. Europese Nederlanders geven gemiddeld een 6,1 voor hun baan, hetgeen aanzienlijk lager is dan onder Caribische Nederlanders met een 7,6. Personen die elders geboren zijn geven gemiddeld een 7.0. Ook is gevraagd naar de tevredenheid over het leven in Caribisch Nederland; dit rapportcijfer verschilt niet naar geboorte(ei)land en is met gemiddeld 8,2 aanzienlijk hoger dan de baantevredenheid. 


\subsection{Pull- en pushfactoren bij huidige baan}

Uit de wetenschappelijke literatuur naar aspecten die een baan meer of minder aantrekkelijk maken, volgt dat er ruwweg drie clusters van factoren onderscheiden kunnen worden. Het gaat om factoren die te maken hebben met de 'werkgerelateerde omstandigheden', met de 'leefomstandigheden', of met het 'sociaal netwerk'.

\subsubsection{Pullfactoren}

Uit de enquête volgt dat het lesgevend personeel in Caribisch Nederland vooral veel 'werkgerelateerde' factoren belangrijk acht om in de huidige baan te (willen) blijven (meerdere antwoorden mogelijk): 'Ik heb een goede band met de leerlingen' (70\%), 'Mijn werk is uitdagend' (56\%), 'Ik heb een vast dienstverband' $(41 \%)$, 'Ik heb een goede band met de ouders van de leerlingen' (41\%) en 'De samenwerking met de collega's is plezierig' (40\%). De aantrekkelijkheid van de functie zit dus voor een deel in de arbeidsvoorwaarden (de zekerheid van een vast contract), maar vooral in het werk zelf: de uitdaging en de prettige relatie met leerlingen, hun ouders en collega's.

Bij factoren rond de 'leefomstandigheden' en het 'sociaal netwerk', wordt veelvuldig aangegeven dat men (onder meer) in de huidige baan wil blijven omdat het leven op het eiland prettig is $(78 \%)$. Verder vindt 51 procent het gevoel van verbondenheid met het eiland een belangrijke reden, en 41 procent noemt het hebben van sociale contacten (zoals vrienden en kennissen) een reden om in de huidige baan (en dus op het eiland) te blijven. Een klein deel van de respondenten (5\%) geeft aan in het geheel geen redenen te hebben om in de huidige baan te blijven. Uit nadere analyse volgt dat het hier niet om een specifieke groep gaat wat betreft achtergrondkenmerken zoals functie, eiland, geboorte(ei)land et cetera.

De belangrijkste 'blijfreden' voor twee derde van de respondenten $(66 \%)$ is werkgerelateerd (vooral: uitdagend werk, en goede band met leerlingen). Voor Caribische Nederlanders is de belangrijkste 'pullfactor' veel vaker werkgerelateerd (voor $84 \%$ van de respondenten) dan voor immigranten $(60 \%)$, het gaat dan onder andere om het hebben van een goede band met de leerlingen, uitdagend werk of een vast dienstverband. Voor immigranten speelt het prettige eilandleven vaker een belangrijke rol, hoewel dat niet verbazend is aangezien zij ook vaak aangeven hiervoor naar het eiland te zijn gekomen. Voor 18 procent van de respondenten is de belangrijkste reden gerelateerd aan de leefomstandigheden en voor 16 procent heeft de belangrijkste 'blijfreden' te maken met het sociale netwerk.

\subsubsection{Pushfactoren}

Bij de pushfactoren, oftewel redenen om de huidige baan te (willen) verlaten, is er veel meer variatie in de antwoorden dan bij de pullfactoren. Anders gezegd, vertrekredenen lijken dus heel persoonlijk en uiteenlopend te zijn. 'Werkgerelateerde' redenen die door een relatief groot aandeel genoemd worden zijn: 'De werklast / werkdruk is (te) hoog' (37\%), 'Het salaris is onvoldoende' $(23 \%)$, 
'Er is nauwelijks sprake van professionalisering van leraren' (21\%), 'Er zijn onvoldoende mogelijkheden voor opleiding en training' (20\%), 'De werksfeer is niet plezierig' (20\%), 'Ik ben op zoek naar een nieuwe uitdaging binnen het onderwijs' (20\%) en 'Ik ben het niet eens met het personeelsbeleid op mijn school' (20\%). Opvallend is echter dat we geen verschillen naar geboorte(ei)land zien als het gaat om de belangrijkste vertrekreden. Hier zien we, in tegenstelling tot de pullfactoren, dat er juist vooral verschillen tussen de eilanden bestaan.

Ook in de interviews kwamen werkgerelateerde redenen als belangrijke factor naar voren om te vertrekken. Het betrof hier het te lage salaris, maar eveneens onvrede over het personeelsbeleid, een onplezierige werksfeer en een gebrekkige organisatie op school (onrust in management, slechte ondersteuning van faciliteiten en bureaucratie). In de interviews worden echter ook genoemd de grote sociale en armoedeproblematiek, die zijn weerslag heeft op de opvoeding van kinderen en op het gedrag van de leerlingen in de klas. Er zijn bovendien cultuurverschillen in de omgang, het pedagogisch-didactische concept dat gehanteerd wordt in het Caribische Nederlandse onderwijs wijkt af van dat in het Europees Nederlandse onderwijs. Soms wordt er gewezen op de 'roddelcultuur' en de discriminatie wat betreft de omgang op de werkvloer, de aanstellingen en de arbeidsvoorwaarden. Bij de pushfactoren gaat het dus deels om de arbeidsvoorwaarden (zoals onvoldoende salaris), maar vooral om de werkinhoud (zoals te hoge werkdruk) en de werkomgeving (bijvoorbeeld onplezierige werksfeer en cultuurverschillen). Weliswaar worden zowel op Bonaire als op Sint Eustatius en Saba vooral werkgerelateerde redenen genoemd - zoals hoge werklast, onvoldoende salaris en matige professionaliseringsmogelijkheden - maar op Sint Eustatius en Saba wordt dit minder vaak genoemd (61\%) dan op Bonaire (76\%).

Veelgenoemde vertrekredenen die te maken hebben met de 'leefomstandigheden' en het 'sociaal netwerk' zijn: 'De kosten van levensonderhoud zijn (te) hoog' (37\%) en 'De onderwijsmogelijkheden / onderwijskwaliteit voor mijn kinderen zijn onvoldoende' (20\%). In de interviews is gewezen op onder meer de hoge kosten van levensmiddelen, woninghuur en vliegtickets. Op Sint Eustatius en Saba wordt vaker dan op Bonaire een reden genoemd die te maken heeft met de leefomstandigheden of het sociaal netwerk. De kleinschaligheid van Sint Eustatius en Saba lijkt hieraan ten grondslag te liggen. Zo wordt daar vaker genoemd dat de recreatiemogelijkheden en medische faciliteiten onvoldoende zijn, dat men is uitgekeken op het eiland, dat de sociale controle benauwend is of dat de partner er geen werk kan vinden. Een fors deel van de respondenten, bijna een vijfde (17\%), geeft aan geheel geen redenen te hebben om de huidige baan te verlaten. Uit nadere analyse volgt dat het hier vooral gaat om Caribische Nederlanders en personen ouder dan 40 jaar.

De belangrijkste vertrekreden is voor de overgrote meerderheid van de respondenten (73\%) werkgerelateerd. We zien hier overigens geen verschillen naar geboorte(ei)land, maar wel naar het eiland waar men werkt. Op Bonaire geeft 76 procent aan dat de belangrijkste vertrekreden werkgerelateerd is, terwijl het op Sint Eustatius en Saba om 61 procent gaat. Voor 15 procent van de respondenten is de belangrijkste vertrekreden gerelateerd aan de leefomstandigheden en voor 12 
procent heeft de belangrijkste vertrekreden te maken met het sociaal netwerk. Op Sint Eustatius en Saba spelen het ontbreken van voorzieningen, de sociale controle, het ontbreken van een sociaal netwerk, en de ontevredenheid in het gezin over bijvoorbeeld het leven op het eiland en het vinden van werk een grotere rol dan op Bonaire.

\subsection{Toekomstverwachtingen}

De hoge lerarenmobiliteit in Caribisch Nederland, zoals onder meer gesignaleerd in de voorstudie van Cörvers, Claessen en Kluijfhout (2015), wordt bevestigd door de enquête onder lesgevend personeel. Ook in de komende jaren kan derhalve een forse uitstroom worden verwacht. Ruim de helft van de respondenten (55\%) die een inschatting kunnen maken over hun (nabije) toekomst ${ }^{28}$, verwacht maximaal vijf jaar in de huidige functie te blijven. Drie tiende (29\%) verwacht minder dan twee jaar de huidige functie te bekleden. Deze cijfers over het verwachte verloop op korte termijn sluiten min of meer aan bij de eerder genoemde uitstroom in de voorbije periode van bijna 15 procent uitstroom van lesgevend personeel per jaar. Ook voor de komende jaren moet er, bij ongewijzigd beleid, rekening worden gehouden met een dergelijke hoge uitstroom op scholen in Caribisch Nederland. Een derde van de respondenten (32\%) verwacht overigens juist langdurig in de huidige functie te blijven. Zij geven aan meer dan tien jaar, dan wel tot hun pensioen in hun baan te blijven.

Verwachtingen over het les blijven geven in het algemeen (niet per se in de huidige functie) laten zien dat een forse groep leraren in een andere lesgevende functie denkt te gaan werken. Het aandeel dat kortdurend (maximaal vijf jaar) les denkt te blijven geven is met 28 procent namelijk veel kleiner dan het aandeel dat kortdurend in de huidige functie denkt te blijven (55\%). Ruim de helft (52\%) verwacht echter juist meer dan tien jaar, dan wel tot hun pensioen les te blijven geven.

Op basis van voorgaande lijkt een fors deel van het lesgevend personeel op korte termijn (binnen vijf jaar) verloren te gaan voor het Caribisch Nederlandse onderwijs. Dit geldt met name voor de Europese Nederlanders. Maar liefst drie kwart (74\%) van hen verwacht binnen vijf jaar de huidige functie te verlaten. Onder Caribische Nederlanders betreft het 'slechts' drie tiende (29\%). Ook als het gaat om het les blijven geven in algemene zin (niet perse in de huidige functie) of het werken in Caribisch Nederland zijn Europese Nederlanders veel mobieler dan Caribische Nederlanders Slechts een kleine groep van de Europese Nederlanders verwacht dus tot het einde van de loopbaan te verblijven in Caribisch Nederland. De inschatting van de toekomstverwachtingen van het lesgevend personeel dat noch in Europees, noch in Caribisch Nederland is geboren, ligt structureel tussen beide groepen in.

28 Een deel van de respondenten gaf aan geen toekomstinschatting te kunnen maken. Het gaat om $14 \%$ bij het item 'a) in huidige functie blijven', en om $20 \%$ bij de items 'b) les blijven geven' en 'c) in Caribisch Nederland blijven werken'. 


\subsection{Terugdringen hoge lerarenmobiliteit}

Er worden hier twee kanttekeningen gemaakt bij de doelstelling van het terugdringen van de hoge lerarenmobiliteit in Caribisch Nederland. Ten eerste moet niet worden vergeten dat schoolleiders vaak moeite hebben om de vacatures naar tevredenheid in te vullen. Het komt vaker voor dat het aantal geschikte kandidaten gering is, waardoor er weinig keuze overblijft. Eilanden zoals in Caribisch Nederland staan in de literatuur bekend als 'remote areas', waarvoor het vaak moeilijk is om geschikt hoger opgeleid personeel te werven (De Hoon en Cörvers, 2016). Zolang nieuw aangestelde leraren het schooljaar op een enigszins acceptabele manier uitzitten, zijn scholen vaak voorlopig geholpen. Er ontstaan vooral problemen als dit gaandeweg het schooljaar niet het geval blijkt te zijn. Het terugdringen van de hoge lerarenmobiliteit heeft dus voor een belangrijk deel betrekking op de samenstelling van een grotere poule van geschikte leraren om uit te kunnen putten. Daardoor kan het risico worden verminderd dat er kandidaten worden aangesteld die na enige maanden gedemotiveerd raken of zelfs uitvallen. Het zou vanzelfsprekend beter zijn om geschikte leraren aan te trekken die ten minste hun tijdelijk contract uitdienen.

Ten tweede kan enig verloop in het lerarenteam van een school wel gewenst zijn om noodzakelijke vernieuwingen te realiseren en frisse ideeën op te doen van jonge leraren of van leraren afkomstig van andere organisaties. Het zijn juist vaak jonge mensen die als nieuwe leerkracht in de school komen werken. Ongeveer de helft van het lesgevende personeel blijkt minder dan vijf jaar in dienst te zijn, bijna een vijfde hooguit twee jaar. Zij kunnen bijdragen aan een grotere vernieuwingsgezindheid, mits er op een goede manier gebruik wordt gemaakt van de dynamiek en de ideeën die nieuwe leraren met zich mee brengen.

Caribische Nederlanders zijn gemiddeld langer werkzaam in de huidige functie (circa 8,5 jaar) dan Europese Nederlanders (ongeveer 5,5 jaar) en personen uit andere (ei)landen (circa 7 jaar). Een vast contract of het vooruitzicht daarop is geen belemmering voor de Caribische Nederlanders die les geven: 95 procent van de Caribische Nederlanders heeft een vast contract of het vooruitzicht daarop. Voor de Europese Nederlanders is dat drie kwart. Dat betekent dat een groot deel van het verloop te verklaren is door de duur van het arbeidscontract van de Europese Nederlanders. Contracten voor één, twee of drie jaar zijn standaard voor nieuwkomers uit Europees Nederland. Daarbij gelden vaak voorwaarden ten aanzien van de terugbetaling van de vergoedingen voor de oversteek- en verhuiskosten als men het contract niet uitdient. De relatief korte contractduur hangt mogelijk ook samen met de verwachtingen van deze groep dat men slechts voor een beperkt aantal jaren wil blijven, en met de voorzichtigheid van de schoolleiding om vaste contracten aan te bieden aan Europese Nederlanders die nog moeten aarden in het Caribisch gebied en wennen aan de verschillen in onderwijs tussen Europees en Caribisch Nederland. 


\subsection{Aanbevelingen}

Ten behoeve van het terugdringen van de hoge lerarenmobiliteit in Caribisch Nederland zullen scholen kritisch moeten kijken naar hun HRM-beleid. In het eerste hoofdstuk is er een overzicht gegeven van de onderdelen van HRM-beleid die voor scholen van belang kunnen zijn. Naast aandacht voor financiële prikkels, is bij de aanstelling en het behoud van leraren aandacht nodig voor de ontwikkelingen van hun vakkennis en pedagogisch-didactische vaardigheden, de motivatie en toewijding van de leraar (in opleiding), het bezit van culturele sensitiviteit, het vermogen om te overtuigen en beïnvloeden, en het vermogen om relaties op te bouwen. Dit vraagt om een breed professionaliseringsbeleid van scholen voor hun lesgevende personeel.

Voor het terugdringen van de hoge lerarenmobiliteit kan de actieve werving van leraren in 'remote areas' zoals Caribisch Nederland het beste worden gericht op leraren die zelf afkomstig zijn uit deze gebieden (i.e. Caribisch Nederland) of uit soortgelijke gebieden, omdat de geselecteerde kandidaten dan ervaring hebben met het werken en leven in 'remote areas'. Door ervaring op te doen met het lesgeven in Caribisch Nederland tijdens de lerarenopleiding ontwikkelt zich een beter begrip van de lokale omstandigheden en cultuur. Regelmatig werkervarings- of stageplekken aanbieden voor stagiaires, onderwijsassistenten en leraren-in-opleidingen van andere (ei)landen draagt tevens bij aan een grotere poule van potentiële sollicitanten die beter geïnformeerd zijn over het werken en leven in Caribisch Nederland. Bovendien kan op deze manier vroegtijdig de selectie van de beste en/of meest geschikte leraren plaatsvinden, wat de kwaliteit en status van de leraren ten goede zal komen. Daarnaast kan worden gedacht aan andere manieren voor de verdere professionalisering van het onderwijs. Een voorbeeld hiervan is het vergroten van de professionele ruimte die leraren van schoolleiders krijgen om zich te ontwikkelen. Andere instrumenten om de kwaliteit van leraren te verhogen zijn inductie- en mentorprogramma's, met als doel de slaagkansen van beginnende leraren te vergroten en de kans op uittrede te verkleinen. Deze programma's blijken zowel op professioneel gebied als in de privésfeer (integratie in de sociale context) positieve effecten te kunnen voortbrengen.

Uit de bevindingen van de eerdere paragrafen kunnen diverse aanknopingspunten gedestilleerd worden om de hoge lerarenmobiliteit in Caribisch Nederland terug te dringen. De aanbevelingen zijn ruwweg in drie clusters onder te brengen, namelijk onder: a) betere voorbereiding en voorlichting, b) betere selectie op motivatie, en c) aantrekkelijkere werkomstandigheden en arbeidsvoorwaarden, inclusief betere professionele begeleiding. Dit laatste cluster valt uiteen in aanbevelingen die op schoolniveau en op bovenschools niveau dienen te worden gerealiseerd. Deze aanbevelingen komen voort uit de volgende vaststellingen. Ten eerste is gebleken dat vooral de Europese Nederlanders en in minder mate ook leraren van buiten Europees en Caribisch Nederland de voorlichting over de werkomstandigheden een onvoldoende geven. Ten tweede is gebleken dat veel Europese Nederlanders vooral voor het leven op het eiland, het avontuur en het klimaat naar Caribisch Nederland komen, waardoor de ambities op professioneel vlak wellicht wat te weinig aandacht 
krijgen in de werving en selectie. Ten derde wordt de werkdruk op Caribisch Nederland als hoog ervaren, en is een betere professionalisering van leraren vereist, met meer uitdagingen, meer mogelijkheden voor onderwijs en training en een beter personeelsbeleid, om te voorkomen dat leraren vertrekken.

Het terugdringen van mobiliteit vereist een gedifferentieerde aanpak bij de werving van de kandidaten in verschillende regio's. Immers blijken uit dit onderzoek structurele verschillen tussen Europese Nederlanders, Caribische Nederlanders en personen van andere (ei)landen. Het gaat dan onder meer om verschillen in verwachtingen (wat denk ik aan te treffen?), in de tevredenheid (wat vind ik er van?) en in de toekomstplannen (hoelang wil ik dit gaan doen?). Bij het ontwikkelen van beleid gericht op het terugdringen van mobiliteit is het (h)erkennen van deze zeer verschillende doelgroepen met hun sterk verschillende motieven en ervaringen dan ook essentieel.

\subsubsection{Voorbereiding en voorlichting}

Een groot deel van het lesgevend personeel, vooral personeel dat niet van origine uit Caribisch Nederland komt, had voorafgaand aan de baan meer informatie over de leef- en werkomstandigheden willen hebben. Het betreft bijvoorbeeld informatie over de hoge kosten van levensonderhoud, het vinden van een geschikte woning, de omgang met de plaatselijke bevolking, de immigratieprocedures, de pensioenvoorziening, het arbeidscontract, de soms gebrekkige voorzieningen en ondersteuning op school, de manier van lesgeven, het onderwijsprogramma, et cetera. De voorbereiding op en voorlichting over het werken en wonen in Caribisch Nederland is dan ook (nog) zeker niet optimaal. Hier valt winst te behalen, omdat negatieve verrassingen de intentie om (langdurig) in het Caribisch Nederlandse onderwijs te werken geen goed zullen doen. Om zoveel mogelijk expertise op te doen, om kosteneffectief te kunnen werven en om kandidaten op een zo goed mogelijk plek bij een onderwijsinstelling in Caribisch Nederland te kunnen plaatsen, dienen de werving en selectie beter te worden afgestemd tussen scholen.

Het past hier om in de voorlichting een goede balans te vinden tussen enerzijds het schetsen van de voordelen en mogelijkheden van het werken in het onderwijs in Caribisch Nederland, en anderzijds het wijzen op de uitdagingen en moeilijkheden waarmee nieuwkomers van overzee kunnen worden geconfronteerd. Het te zeer benadrukken van het eerste leidt wellicht tot te veel 'gelukszoekers', maar te veel nadruk op het tweede kan geschikte kandidaten afschrikken.

- Aanbeveling 1: Zorg in een zo vroeg mogelijk stadium voor een eerlijke, duidelijke voorlichting over het wonen en werken op het eiland.Hier lijkt niet alleen een rol in de voorlichting voor de scholen weggelegd tijdens de werving van personeel, maar zou al in een eerdere fase 'centraal' gefaciliteerd kunnen worden. Denk bijvoorbeeld aan het organiseren van informatiebijeenkomsten in Europees Nederland voor personen die geïnteresseerd zijn in eventuele migratie. Faciliteer het leggen van contacten tussen geïnteresseerden en leraren die praktijkervaring hebben in Caribisch Nederland. Wellicht kunnen er ook 
gespecialiseerde recruiters worden ingezet die goed bekend zijn met bijvoorbeeld verschillen in cultuur en het onderwijs tussen Caribisch Nederland en Europees Nederland, en veel ervaring hebben het selecteren van geschikte kandidaten.

- Aanbeveling 2: Probeer de poule van kandidaten die ervaring hebben in Caribisch Nederland groter te maken door regelmatig werkervarings- of stageplekken aan te bieden voor stagiaires, onderwijsassistenten en leraren-inopleidingen van andere (ei)landen.

- $\quad$ Aanbeveling 3: Tracht zoveel mogelijk samen te werken met andere scholen en overheden bij de voorlichting en de werving en selectie van kandidaten. Dit is niet alleen goedkoper, maar kan ook leiden tot een betere match tussen de kandidaat en de betreffende school in Caribisch Nederland. Gezien de hoge uitstroom zal dit zich in zeer korte termijn al terugverdienen.

\subsubsection{Motivatie}

De redenen om les te geven in Caribisch Nederland zijn uiteenlopend. Dit kan gaan van 'avontuur', 'spannende uitdaging' en 'mooi weer' tot 'een bijdrage willen leveren aan de (onderwijs)ontwikkeling van het eiland. Bovendien dient men zich voldoende bewust te zijn van de culturele verschillen en de verschillen in pedagogischdidactische aanpak bij het lesgeven. Het mee willen helpen aan de verbetering van de onderwijskwaliteit op een eiland met - vergeleken met Europees Nederland sociaal-economische achterstanden, is bijvoorbeeld een krachtige beweegreden waarbij eventuele tegenslagen ingecalculeerd lijken. lemand die in Caribisch Nederland komt werken om het onderwijs vooruit te helpen, zal vermoedelijk meer geneigd zijn om zich langer te committeren aan de school en/of het eiland, en zich minder uit het veld laten slaan bij eventuele tegenslag. Maar ook hier dient gewaakt te worden voor te grote idealen of ambities. Reële verwachtingen van wat bereikt kan worden zijn noodzakelijk om al te grote teleurstellingen te vermijden.

- Aanbeveling 4: Zet bij het aantrekken van nieuw personeel in op personeel dat zich wil committeren aan het eiland. Biedt daarbij persoonlijke, passende begeleiding/coaching aan om nieuwe leraren indien nodig vertrouwd te maken met verschillen in cultuur en lesgeven ten opzichte van wat ze gewend zijn.

\subsubsection{Arbeidsvoorwaarden en -omstandigheden en HRM-beleid}

Een belangrijke strategie voor het streven naar een stabielere lerarenpopulatie is het reduceren van het hoge verloop. Uit dit onderzoek volgt dat vooral direct aan het werk gerelateerde factoren het belangrijkst zijn om de huidige baan te verlaten. Het zijn dan ook deze werkgerelateerde factoren waar de meeste winst behaald kan worden. Op het gebied van arbeidsomstandigheden en -voorwaarden zijn de hieronder genoemde aspecten op schoolniveau van belang om te tevredenheid en bereidheid/mogelijkheid om (langdurig) te blijven in een lesgevende functie in Caribisch Nederland te vergroten. Daarbij is een bekwaam en gedegen management 
en bestuur van cruciaal belang om de kwaliteit en continuïteit van het onderwijs te waarborgen.

- Aanbeveling 5: Communiceer duidelijk en tijdig de carrièremogelijkheden van elke leraar evenals de vereisten voor een vast contract. Daarvoor moeten de formatieplannen op tijd klaar zijn, maar moet ook met leraren in gesprek worden gegaan over de carrièremogelijkheden bij de schoolorganisatie, over het persoonlijke functioneren en het persoonlijke ontwikkelplan.

- Aanbeveling 6: Heb oog voor personeel dat in de knel dreigt te komen door een hoge werkdruk. De ervaren werkdruk is hoog en kan niet alleen leiden tot tijdelijke uitval (verzuim), maar ook tot de beslissing om de functie of het onderwijs in zijn geheel te verlaten. Zeker op scholen met een grote zwakke leerlingenpopulatie lijkt ontlasting van lesgevend personeel door extra ondersteuning zinvol (bijvoorbeeld meer onderwijsassistenten).

- Aanbeveling 7: Investeer in goede onderwijsfaciliteiten op school. Goed onderwijs vergt goede leraren, maar vergt ook een goede omgeving met de noodzakelijke voorzieningen zoals goede lesmaterialen, airconditioning, wifi, en dergelijke.

- Aanbeveling 8: Faciliteer de professionele ontwikkeling. Het werken in het onderwijs wordt door velen uitdagend en daardoor aantrekkelijk gevonden. Het faciliteren van verdere ontwikkeling/professionalisering, bijvoorbeeld via docentcoaches, opleidings- en trainingsfaciliteiten, kan ertoe bijdragen dat een functie binnen het onderwijs langdurig uitdagend blijft.

Scholen dienen naar onze opvatting echter ook samen te werken om het wervingsen personeelsbeleid te optimaliseren. Zodra hiervan sprake is, ontstaat er feitelijk een eilandenbreed bovenschools arbeidsmarktbeleid voor leraren. Zaken die dan geregeld moeten worden liggen vaak buiten de doorzettingsmacht van de schooldirectie. Op dat moment is het tevens van groot belang dat de verschillende overheden dit gezamenlijke beleid ondersteunen, stimuleren en mogelijk zelfs mee organiseren en regelen. Belangrijk is dan wel dat de overheden zich van voldoende draagvlak onder de scholen verzekerd weten. Bij het overwegen van extra financiële prikkels in de vorm van bijvoorbeeld loonsverhogingen voor nieuwe of zittende leraren, is het van belang duidelijkheid te hebben over wie men beoogd aan te trekken of te behouden. Wellicht is daarbij afstemming nodig tussen scholen. Financiële prikkels moeten onderdeel uitmaken van de werving en selectie, het arbeidsvoorwaardenpakket, het professionaliseringsbeleid ('talentbeleid') en het HRM-beleid als geheel. Daarvoor is vaak maatwerk nodig per school en functiegroep, waarbij ook de situatie op de eilanden van belang is (bovenwinds versus benedenwinds) en uiteraard de herkomst en professionele achtergrond van de leraar.

- Aanbeveling 9: Bied meer mogelijkheden voor doorstroom en carrièreperspectieven van leraren binnen en tussen onderwijsinstellingen in Caribisch Nederland. Probeer vanuit de scholen een gezamenlijk talentbeleid te ontwikkelen. Het lijkt in elk geval voor de hand te liggen dat Sint Eustatius en 
Saba meer gaan samenwerken met Sint Maarten en andere Engelstalige eilanden in het Caribische gebied (zoals Jamaica), en eventueel Aruba, en dat Bonaire de banden aanhaalt met Curaçao en Aruba.

- Aanbeveling 10: Bekijk of er op sommige punten tegemoet kan worden gekomen aan de hoge kosten van levensonderhoud. Wellicht dat er specifiek voor leraren goedkopere collectieve (zorg)verzekeringen, kwijtschelding van een deel van de studieschuld, gebruik van computer- of internetfaciliteiten (gratis wifi), of reisvergoedingen voor het bezoeken van familie en vrienden kunnen worden geregeld. Wellicht kunnen scholen ook gezamenlijke initiatieven nemen bij het creëren van een aantrekkelijk arbeidsvoorwaardenpakket.

- Aanbeveling 11: Creëer een structurele lerarenopleiding op Bonaire en/of maak afstandsonderwijs beter mogelijk. De deelname aan de LOFO op Bonaire wordt over het algemeen als positief ervaren en leidt op termijn waarschijnlijk tot een lager verloop van leraren. De lerarenopleiding zou wellicht kunnen worden uitgebreid voor het vo. Om de relatief hoge kosten per student vanwege de kleinschaligheid te drukken, zou men zoveel mogelijk de curriculae van de verschillende lerarenopleidingen kunnen laten overlappen.

\subsection{Tot slot}

In 2011 is de Onderwijsagenda voor Caribisch Nederland ('Samen werken aan kwaliteit') opgesteld door het ministerie van Onderwijs, Cultuur en Wetenschap, de eilandbesturen en de schoolbesturen. De doelstelling van deze agenda betreft het vergroten van de onderwijskwaliteit in Caribisch Nederland, waarbij de scholen in 2016 op een, naar Europees en Caribisch Nederlandse maatstaven, aanvaardbaar niveau is. Recent is er door onderzoeksbureau Ecorys een evaluatie gehouden van de Onderwijsagenda 2011-2015 (Visser et al, 2016). In dit rapport is, in het kader van voorliggend onderzoek, met name de evaluatie van 'Prioriteit 2: Versterking leerkrachten, schoolbesturen en schoolleiding' relevant om kort te bespreken.

Ecorys concludeert dat - hoewel de opgestelde actielijnen zeer complex waren en de doelstellingen niet realistisch voor de gestelde termijn - er belangrijke resultaten zijn behaald. Het gaat dan vooral om (zie Visser et al, 2013, p.13):

- Het aantal onbevoegde leraren is sinds 2010 afgenomen, vooral door vertrek van onbevoegden en instroom van bevoegden.

- De beschikking over bekwaamheidsgelden heeft scholen de vrijheid gegeven om zelf invulling te geven aan de trainingsbehoeften van leraren.

- Voor het bieden van een duurzame oplossing voor de lerarenopleiding is een regionale samenwerking (UniCarib) gerealiseerd tussen de universiteiten van Sint Maarten, Curaçao en Aruba en het Instituto Pedagogica Arubano (IPA).

- Scholen hebben via coachingstrajecten directe begeleiding aangeboden gekregen. De coaching in het po is succesvol geweest, in het vo zijn de resultaten nog matig. Voor het mbo is nog geen apart coachingstraject opgezet.

In het licht van voorliggend onderzoek, lijken er de afgelopen jaren dus reeds goede stappen gezet te zijn om een stabieler en kwalitatief sterker lerarenbestand op te 
bouwen. Dit ondanks dat, zoals uit de interviews is gebleken, de leef- en schoolsituatie op de eilanden soms zeer moeilijk zijn voor leraren. Een betere voorlichting en werving, en een beter gekwalificeerd en gecoacht lerarenkorps kan echter beter omgaan met de uitdagingen die de leerlingenpopulatie in Caribisch Nederland met zich meebrengt. Het bieden van een professionele school- en leercultuur en betere trainingsmogelijkheden voor leraren, aangepast op de behoefte van de leraar, komen tegemoet aan de behoefte van leraren om zich verder te professionaliseren. Deze ontwikkelmogelijkheden kunnen het werken in het onderwijs voor hen uitdagend houden, waardoor leraren zich langdurig willen blijven committeren aan het les geven in een onderwijsinstelling in Caribisch Nederland. 


\section{Referenties}

Hoon, M. de \& Cörvers, F. (2016). Literatuuronderzoek ten behoeve van Caribisch Nederland, Push- en pulffactoren bij werving, selectie en behoud van leraren in afgelegen gebieden. ROA-TR-2016/1, Maastricht University.

Cörvers, F., Claessen, J. \& Kluijfhout, E. (2015). Vooronderzoek, Onderwijsarbeidsmarkt en lerarenopleidingen op Caribisch Nederland. ROA-TR-2015/2, Open Universiteit / Maastricht University.

Lunn, S. (1997). Rural strategies project. Brisbane: Priority Country Area Program.

Visser, M., Boom, E. van der, Tossings, S., Aa, R. van der (2016) Evaluatie Onderwijsagenda Caribisch Nederland. Rotterdam: Ecorys.

Yarrow, A., Ballantyne, R., Hansford, B., Herschell, P., en Millwater, J. (1999). Teaching in rural and remote schools: A literature review. Teaching and Teacher Education, 15(1), 1-13. 


\section{Bijlage A: Regressieanalyses}

Noot: vanwege het relatief kleine aantal respondenten en het relatief grote aantal predictoren, is een ruim significantieniveau van $\alpha=10 \%$ aangenomen. Alle statistisch significante $p$-waarden zijn dikgedrukt weergegeven.

Tabel A.1 - Multinomiale regressieanalyse 'Wat was voor u de belangrijkste reden om naar het eiland te komen waar u nu werkt?' (referentiecategorie $=\mathrm{lk}$ ben verhuisd om hier te gaan werken)

\begin{tabular}{|c|c|c|c|c|}
\hline & $B$ & SE & $\operatorname{Exp}(B)$ & p-waarde \\
\hline \multicolumn{5}{|l|}{ Ik ben meeverhuisd met mijn partner en/of familie } \\
\hline Intercept & $-1,79$ & 0,93 & & 0,05 \\
\hline Sint Eustatius, Saba & $-1,03$ & 0,82 & 0,36 & 0,21 \\
\hline $\mathrm{vo} / \mathrm{mbo}$ & $-0,13$ & 0,57 & 0,88 & 0,82 \\
\hline Functie: leraar & $-0,67$ & 0,61 & 0,51 & 0,27 \\
\hline Geboren Caribisch NL & 0,38 & 0,90 & 1,47 & 0,67 \\
\hline Geboren elders & 0,99 & 0,60 & 2,69 & 0,10 \\
\hline 40 jaar of ouder & $-0,08$ & 0,55 & 0,92 & 0,88 \\
\hline Vrouw & 0,26 & 0,73 & 1,30 & 0,72 \\
\hline \multicolumn{5}{|c|}{ Ik ben teruggekeerd naar het eiland waar ik ben geboren/opgegroeid } \\
\hline Intercept & $-20,60$ & 1,40 & & 0,00 \\
\hline Sint Eustatius, Saba & $-0,18$ & 0,82 & 0,83 & 0,82 \\
\hline $\mathrm{vo} / \mathrm{mbo}$ & 0,44 & 0,73 & 1,55 & 0,55 \\
\hline Functie: leraar & $-1,61$ & 0,71 & 0,20 & 0,02 \\
\hline Geboren Caribisch NL & 21,40 & 0,71 & $>100$ & 0,00 \\
\hline Geboren elders & \multicolumn{4}{|c|}{ niet berekenbaar } \\
\hline 40 jaar of ouder & 0,47 & 0,70 & 1,59 & 0,51 \\
\hline Vrouw & $-0,59$ & 1,00 & 0,55 & 0,56 \\
\hline \multicolumn{5}{|c|}{ Niet van toepassing, ik heb hier altijd al gewoond } \\
\hline Intercept & $-2,33$ & 1,31 & & 0,07 \\
\hline Sint Eustatius, Saba & $-1,07$ & 0,75 & 0,34 & 0,16 \\
\hline $\mathrm{vo} / \mathrm{mbo}$ & $-1,44$ & 0,63 & 0,24 & 0,02 \\
\hline Functie: leraar & $-1,11$ & 0,61 & 0,33 & 0,07 \\
\hline Geboren Caribisch NL & 4,15 & 1,13 & 63,40 & 0,00 \\
\hline Geboren elders & 2,51 & 1,14 & 12,36 & 0,03 \\
\hline 40 jaar of ouder & $-0,07$ & 0,59 & 0,93 & 0,90 \\
\hline Vrouw & $-0,29$ & 0,92 & 0,75 & 0,75 \\
\hline \multicolumn{5}{|l|}{ Anders } \\
\hline Intercept & $-1,99$ & 1,21 & & 0,10 \\
\hline Sint Eustatius, Saba & $-1,11$ & 1,16 & 0,33 & 0,34 \\
\hline $\mathrm{vo} / \mathrm{mbo}$ & $-0,61$ & 0,90 & 0,54 & 0,50 \\
\hline Functie: leraar & $-0,28$ & 0,87 & 0,76 & 0,75 \\
\hline Geboren Caribisch NL & 0,23 & 1,24 & 1,26 & 0,85 \\
\hline Geboren elders & 0,60 & 0,86 & 1,82 & 0,48 \\
\hline 40 jaar of ouder & 1,18 & 0,89 & 3,25 & 0,19 \\
\hline Vrouw & $-1,35$ & 0,85 & 0,26 & 0,11 \\
\hline
\end{tabular}

Bron: Enquête lerarenmobiliteit Caribisch Nederland, ROA (2016) 
Tabel A.2 - Lineaire regressieanalyse: Hoe tevreden bent u over de informatie die u voorafgaand aan uw aankomst heeft gekregen over de leefomstandigheden in Caribisch Nederland?

\begin{tabular}{l|cccc}
\hline & $\boldsymbol{B}$ & $\boldsymbol{S E}$ & $\boldsymbol{B e ̀ t a}$ & $\boldsymbol{p}$-waarde \\
\hline Intercept & 7,02 & 0,68 & & $\mathbf{0 , 0 0}$ \\
Sint Eustatius, Saba & 0,00 & 0,46 & 0,00 & 0,99 \\
vo/mbo & $-0,56$ & 0,41 & $-0,13$ & 0,17 \\
Functie: leraar & $-0,60$ & 0,51 & $-0,11$ & 0,23 \\
Geboren Caribisch NL & 1,73 & 0,62 & 0,27 & $\mathbf{0 , 0 1}$ \\
Geboren elders & $-0,02$ & 0,47 & $-0,01$ & 0,96 \\
40 jaar of ouder & $-0,04$ & 0,42 & $-0,01$ & 0,92 \\
Vrouw & $-0,11$ & 0,48 & $-0,02$ & 0,81 \\
\hline
\end{tabular}

Bron: Enquête lerarenmobiliteit Caribisch Nederland, ROA (2016)

Tabel A.3 - Lineaire regressieanalyse: Hoe tevreden bent u over de informatie die u voorafgaand aan uw aankomst heeft gekregen over de werkomstandigheden in Caribisch Nederland?

\begin{tabular}{l|cccc}
\hline & $\boldsymbol{B}$ & $\boldsymbol{S E}$ & $\boldsymbol{B e ̀ t a}$ & $\boldsymbol{p}$-waarde \\
\hline Intercept & 6,17 & 0,69 & & $\mathbf{0 , 0 0}$ \\
Sint Eustatius, Saba & 0,42 & 0,46 & 0,09 & 0,36 \\
vo/mbo & $-0,69$ & 0,41 & $-0,16$ & $\mathbf{0 , 1 0}$ \\
Functie: leraar & $-0,38$ & 0,51 & $-0,07$ & 0,46 \\
Geboren Caribisch NL & 1,88 & 0,63 & 0,28 & $\mathbf{0 , 0 0}$ \\
Geboren elders & 0,87 & 0,47 & 0,18 & $\mathbf{0 , 0 7}$ \\
40 jaar of ouder & 0,20 & 0,43 & 0,05 & 0,63 \\
Vrouw & $-0,81$ & 0,49 & $-0,16$ & 0,10 \\
\hline
\end{tabular}

Bron: Enquête lerarenmobiliteit Caribisch Nederland, ROA (2016)

Tabel A.4 - Logistische regressieanalyse: Terugkijkend, had u meer informatie over de leefomstandigheden willen ontvangen?

\begin{tabular}{l|cccc}
\hline & $\boldsymbol{B}$ & $\boldsymbol{S E}$ & $\boldsymbol{E x p}(\boldsymbol{B})$ & $\boldsymbol{p}$-waarde \\
\hline Intercept & $-0,18$ & 0,69 & 0,84 & 0,80 \\
Sint Eustatius, Saba & 0,11 & 0,45 & 1,11 & 0,81 \\
vo/mbo & $-0,29$ & 0,41 & 0,75 & 0,48 \\
Functie: leraar & $-0,11$ & 0,52 & 0,90 & 0,84 \\
Geboren Caribisch NL & $-0,93$ & 0,65 & 0,39 & 0,15 \\
Geboren elders & $-0,61$ & 0,47 & 0,54 & 0,20 \\
40 jaar of ouder & 0,38 & 0,43 & 1,46 & 0,39 \\
Vrouw & 0,25 & 0,49 & 1,29 & 0,61 \\
\hline
\end{tabular}


Tabel A.5 - Logistische regressieanalyse: Terugkijkend, had u meer informatie over de werkomstandigheden willen ontvangen?

\begin{tabular}{l|cccc}
\hline & $\boldsymbol{B}$ & $\boldsymbol{S E}$ & $\boldsymbol{E x p}(\boldsymbol{B})$ & $\boldsymbol{p}$-waarde \\
\hline Intercept & $-0,44$ & 0,71 & 0,64 & 0,53 \\
Sint Eustatius, Saba & $-0,86$ & 0,47 & 0,42 & $\mathbf{0 , 0 7}$ \\
vo/mbo & $-0,36$ & 0,42 & 0,70 & 0,40 \\
Functie: leraar & 0,03 & 0,53 & 1,03 & 0,96 \\
Geboren Caribisch NL & $-1,12$ & 0,65 & 0,33 & $\mathbf{0 , 0 8}$ \\
Geboren elders & $-0,77$ & 0,49 & 0,46 & 0,11 \\
40 jaar of ouder & 0,71 & 0,45 & 2,03 & 0,11 \\
Vrouw & 1,28 & 0,52 & 3,59 & $\mathbf{0 , 0 1}$ \\
\hline
\end{tabular}

Bron: Enquête lerarenmobiliteit Caribisch Nederland, ROA (2016)

Tabel A.6 - Lineaire regressieanalyse: Hoe tevreden bent u met uw leven in zijn geheel?

\begin{tabular}{l|cccc}
\hline & $\boldsymbol{B}$ & $\boldsymbol{S E}$ & Bèta & p-waarde \\
\hline Intercept & 7,85 & 0,36 & & 0,00 \\
Sint Eustatius, Saba & $-0,12$ & 0,25 & $-0,04$ & 0,64 \\
vo/mbo & $-0,01$ & 0,22 & $-0,01$ & 0,95 \\
Functie: leraar & $-0,03$ & 0,24 & $-0,01$ & 0,91 \\
Geboren Caribisch NL & 0,16 & 0,28 & 0,05 & 0,57 \\
Geboren elders & 0,32 & 0,25 & 0,11 & 0,19 \\
40 jaar of ouder & 0,25 & 0,21 & 0,09 & 0,24 \\
Vrouw & 0,17 & 0,27 & 0,05 & 0,53 \\
\hline Bron: Enquête lerarenmobiliteit Caribisch Nederland, ROA (2016)
\end{tabular}

Bron: Enquête lerarenmobiliteit Caribisch Nederland, ROA (2016)

Tabel A.7 - Lineaire regressieanalyse: Hoe tevreden bent u met uw baan?

\begin{tabular}{l|cccc}
\hline & $\boldsymbol{B}$ & $\boldsymbol{S E}$ & Bèta & p-waarde \\
\hline Intercept & 6,71 & 0,55 & & $\mathbf{0 , 0 0}$ \\
Sint Eustatius, Saba & 0,31 & 0,39 & 0,06 & 0,43 \\
vo/mbo & $-0,83$ & 0,33 & $-0,19$ & $\mathbf{0 , 0 1}$ \\
Functie: leraar & $-0,34$ & 0,37 & $-0,07$ & 0,36 \\
Geboren Caribisch NL & 1,28 & 0,43 & 0,25 & $\mathbf{0 , 0 0}$ \\
Geboren elders & 0,80 & 0,38 & 0,17 & $\mathbf{0 , 0 4}$ \\
40 jaar of ouder & 0,06 & 0,32 & 0,01 & 0,85 \\
Vrouw & 0,07 & 0,41 & 0,01 & 0,86 \\
\hline
\end{tabular}

Bron: Enquête lerarenmobiliteit Caribisch Nederland, ROA (2016)

Tabel A.8 - Logistische regressieanalyse: Geeft respondent aan geen reden te hebben om in de baan te blijven?

\begin{tabular}{l|cccc}
\hline & $\boldsymbol{B}$ & $\boldsymbol{S E}$ & $\boldsymbol{E x p ( B )}$ & $\boldsymbol{p}$-waarde \\
\hline Intercept & $-2,81$ & 1,20 & 0,06 & 0,06 \\
Sint Eustatius, Saba & $-0,03$ & 0,85 & 0,97 & 0,97 \\
vo/mbo & $-0,30$ & 0,80 & 0,74 & 0,74 \\
Functie: leraar & 0,11 & 0,86 & 1,11 & 1,11 \\
Geboren Caribisch NL & $-0,60$ & 0,94 & 0,55 & 0,55 \\
\hline
\end{tabular}




\begin{tabular}{l|cccc}
\hline Geboren elders & $-1,53$ & 1,13 & 0,22 & 0,22 \\
40 jaar of ouder & 0,77 & 0,79 & 2,16 & 2,16 \\
Vrouw & $-0,09$ & 0,85 & 0,91 & 0,91 \\
\hline \multicolumn{4}{l}{ Bron: Enquête lerarenmobiliteit Caribisch Nederland, ROA (2016) }
\end{tabular}

Tabel A.9 - Logistische regressieanalyse: Geeft respondent aan geen reden te hebben om de baan te verlaten?

\begin{tabular}{l|cccc}
\hline & $\boldsymbol{B}$ & $\boldsymbol{S E}$ & $\boldsymbol{E x p ( B )}$ & $\boldsymbol{p}$-waarde \\
\hline Intercept & $-2,67$ & 0,81 & 0,07 & $\mathbf{0 , 0 0}$ \\
Sint Eustatius, Saba & $-0,66$ & 0,60 & 0,52 & 0,27 \\
vo/mbo & 0,31 & 0,49 & 1,37 & 0,52 \\
Functie: leraar & $-0,05$ & 0,48 & 0,95 & 0,92 \\
Geboren Caribisch NL & 1,45 & 0,60 & 4,27 & $\mathbf{0 , 0 1}$ \\
Geboren elders & 0,78 & 0,56 & 2,17 & 0,17 \\
40 jaar of ouder & 1,29 & 0,48 & 3,62 & $\mathbf{0 , 0 1}$ \\
Vrouw & $-0,59$ & 0,55 & 0,56 & 0,29 \\
\hline
\end{tabular}

Bron: Enquête lerarenmobiliteit Caribisch Nederland, ROA (2016)

Tabel A.10 - Multinomiale regressieanalyse: Welke van de genoemde redenen om in uw huidige baan te blijven is voor u het belangrijkst? (referentiecategorie = Arbeidsvoorwaarden en -omstandigheden)

\begin{tabular}{|c|c|c|c|c|c|}
\hline & & $B$ & SE & $\operatorname{Exp}(B)$ & $p$-waarde \\
\hline \multicolumn{6}{|l|}{ Leefomstandigheden } \\
\hline & Intercept & $-2,22$ & 0,95 & & 0,02 \\
\hline & Sint Eustatius, Saba & 0,25 & 0,54 & 1,29 & 0,64 \\
\hline & $\mathrm{vo} / \mathrm{mbo}$ & 0,10 & 0,48 & 1,10 & 0,84 \\
\hline & Functie: leraar & 1,45 & 0,78 & 4,27 & 0,06 \\
\hline & Geboren Caribisch NL & $-2,24$ & 1,07 & 0,11 & 0,04 \\
\hline & Geboren elders & $-0,02$ & 0,50 & 0,98 & 0,97 \\
\hline & 40 jaar of ouder & $-0,05$ & 0,48 & 0,95 & 0,92 \\
\hline & Vrouw & $-0,11$ & 0,54 & 0,89 & 0,83 \\
\hline \multicolumn{6}{|l|}{ Sociaal netwerk } \\
\hline & Intercept & $-2,25$ & 0,88 & & 0,01 \\
\hline & Sint Eustatius, Saba & 0,06 & 0,58 & 1,06 & 0,92 \\
\hline & $\mathrm{vo} / \mathrm{mbo}$ & 0,12 & 0,48 & 1,13 & 0,80 \\
\hline & Functie: leraar & 1,08 & 0,66 & 2,94 & 0,10 \\
\hline & Geboren Caribisch NL & $-0,28$ & 0,62 & 0,76 & 0,66 \\
\hline & Geboren elders & 0,26 & 0,53 & 1,30 & 0,62 \\
\hline & 40 jaar of ouder & 0,06 & 0,47 & 1,06 & 0,90 \\
\hline & Vrouw & $-0,19$ & 0,56 & 0,83 & 0,74 \\
\hline
\end{tabular}

NB: Exclusief 'Er zijn geen redenen waarom ik in mijn huidige baan zou blijven' en open antwoorden Bron: Enquête lerarenmobiliteit Caribisch Nederland, ROA (2016) 
Tabel A.11 - Multinomiale regressieanalyse: Welke van de genoemde redenen om uw huidige baan te verlaten is voor $u$ het belangrijkst? (referentiecategorie = Arbeidsvoorwaarden en -omstandigheden)

\begin{tabular}{|c|c|c|c|c|c|}
\hline & & $B$ & $S E$ & $\operatorname{Exp}(B)$ & p-waarde \\
\hline \multicolumn{6}{|l|}{ Leefomstandigheden } \\
\hline & Intercept & $-1,28$ & 0,91 & & 0,16 \\
\hline & Sint Eustatius, Saba & 0,20 & 0,63 & 1,22 & 0,75 \\
\hline & $\mathrm{vo} / \mathrm{mbo}$ & 0,21 & 0,50 & 1,23 & 0,68 \\
\hline & Functie: leraar & 0,05 & 0,64 & 1,06 & 0,93 \\
\hline & Geboren Caribisch NL & $-0,75$ & 0,75 & 0,47 & 0,32 \\
\hline & Geboren elders & $-0,39$ & 0,58 & 0,68 & 0,50 \\
\hline & 40 jaar of ouder & $-0,50$ & 0,54 & 0,60 & 0,35 \\
\hline & Vrouw & 0,03 & 0,67 & 1,03 & 0,96 \\
\hline \multicolumn{6}{|l|}{ Sociaal netwerk } \\
\hline & Intercept & $-0,49$ & 0,90 & & 0,59 \\
\hline & Sint Eustatius, Saba & 1,87 & 0,63 & 6,50 & 0,00 \\
\hline & $\mathrm{vo} / \mathrm{mbo}$ & 0,07 & 0,61 & 1,07 & 0,91 \\
\hline & Functie: leraar & $-0,96$ & 0,65 & 0,38 & 0,14 \\
\hline & Geboren Caribisch NL & $-0,44$ & 0,81 & 0,64 & 0,59 \\
\hline & Geboren elders & $-0,41$ & 0,73 & 0,66 & 0,57 \\
\hline & 40 jaar of ouder & $-0,28$ & 0,61 & 0,76 & 0,65 \\
\hline & Vrouw & $-1,29$ & 0,71 & 0,27 & 0,07 \\
\hline
\end{tabular}

NB: Exclusief 'Er zijn geen redenen waarom ik mijn huidige baan zou verlaten' en open antwoorden Bron: Enquête lerarenmobiliteit Caribisch Nederland, ROA (2016)

Tabel A.12 - Logistische regressieanalyse: Verwacht respondent minder dan vijf jaar in huidige functie te werken?

\begin{tabular}{l|cccc}
\hline & $\boldsymbol{B}$ & $\boldsymbol{S E}$ & $\boldsymbol{E x p ( B )}$ & $\boldsymbol{p}$-waarde \\
\hline Intercept & 1,18 & 0,66 & 3,26 & $\mathbf{0 , 0 7}$ \\
Sint Eustatius, Saba & $-0,15$ & 0,47 & 0,75 & 0,75 \\
vo/mbo & $-0,63$ & 0,41 & 0,13 & 0,13 \\
Functie: leraar & $-0,21$ & 0,44 & 0,63 & 0,63 \\
Geboren Caribisch NL & $-2,86$ & 0,56 & 0,00 & $\mathbf{0 , 0 0}$ \\
Geboren elders & $-1,74$ & 0,48 & 0,00 & $\mathbf{0 , 0 0}$ \\
40 jaar of ouder & $-0,28$ & 0,38 & 0,46 & 0,46 \\
Vrouw & 1,28 & 0,50 & 0,01 & $\mathbf{0 , 0 1}$ \\
\hline
\end{tabular}

Bron: Enquête lerarenmobiliteit Caribisch Nederland, ROA (2016) 
Tabel A.13 - Logistische regressieanalyse: Verwacht respondent minder dan vijf jaar les te geven?

\begin{tabular}{l|cccc}
\hline & $\boldsymbol{B}$ & $\boldsymbol{S E}$ & $\boldsymbol{E x p}(\boldsymbol{B})$ & $\boldsymbol{p}$-waarde \\
\hline Intercept & $-0,57$ & 0,70 & 0,56 & 0,41 \\
Sint Eustatius, Saba & $-0,84$ & 0,53 & 0,43 & 0,11 \\
vo/mbo & 0,15 & 0,45 & 1,16 & 0,74 \\
Functie: leraar & $-0,33$ & 0,53 & 0,72 & 0,53 \\
Geboren Caribisch NL & $-2,06$ & 0,69 & 0,13 & $\mathbf{0 , 0 0}$ \\
Geboren elders & $-0,51$ & 0,46 & 0,60 & 0,28 \\
40 jaar of ouder & 0,25 & 0,43 & 1,28 & 0,56 \\
Vrouw & 0,48 & 0,47 & 1,62 & 0,31 \\
\hline \multicolumn{2}{l}{ Bron: Enquête lerarenmobiliteit Caribisch Nederland, ROA (2016) }
\end{tabular}

Tabel A.14 - Logistische regressieanalyse: Verwacht respondent minder dan vijf jaar te werken in Caribisch Nederland?

\begin{tabular}{l|cccc}
\hline & $\boldsymbol{B}$ & $\boldsymbol{S E}$ & $\boldsymbol{E x p}(\boldsymbol{B})$ & $\boldsymbol{p}$-waarde \\
\hline Intercept & 0,65 & 0,67 & 1,92 & 0,33 \\
Sint Eustatius, Saba & 0,11 & 0,51 & 1,12 & 0,82 \\
vo/mbo & $-0,94$ & 0,47 & 0,39 & $\mathbf{0 , 0 5}$ \\
Functie: leraar & $-0,16$ & 0,51 & 0,85 & 0,76 \\
Geboren Caribisch NL & $-3,48$ & 0,75 & 0,03 & $\mathbf{0 , 0 0}$ \\
Geboren elders & $-2,00$ & 0,53 & 0,14 & $\mathbf{0 , 0 0}$ \\
40 jaar of ouder & 0,16 & 0,45 & 1,17 & 0,72 \\
Vrouw & 0,65 & 0,52 & 1,92 & 0,22 \\
\hline \multicolumn{2}{l}{ Bron: Enquête lerarenmobiliteit Caribisch Nederland, ROA (2016) }
\end{tabular}




\section{Bijlage B: Tabellenboek}

In deze bijlage worden voor alle vragen uit de enquête frequentieverdelingen getoond, voor zover deze nog niet elders in het rapport gepresenteerd zijn.

Tabel B.1 - In welke onderwijssector bent u werkzaam, meerdere antwoorden mogelijk $(\mathrm{n}=197)$

\begin{tabular}{lcclcc}
\hline Indeling hoofdsector & Aantal & Percentage & (Tevens) werkzaam in sector \\
\hline po & 87 & $44 \%$ & po & 87 & $100 \%$ \\
& & & vo & 3 & $3 \%$ \\
& & & mbo & 2 & $2 \%$ \\
vo/mbo & & anders & 3 & $3 \%$ \\
& 110 & $56 \%$ & po & 0 & $0 \%$ \\
& & & vo & 78 & $71 \%$ \\
& & & mbo & 35 & $32 \%$ \\
& & & anders & 2 & $2 \%$ \\
\hline
\end{tabular}

Bron: Enquête lerarenmobiliteit Caribisch Nederland, ROA (2016)

Tabel B.2 - Samengestelde tabel: eiland, onderwijssector en functie

\begin{tabular}{|c|c|c|c|c|}
\hline & & & Aantal & Percentage \\
\hline \multirow[t]{4}{*}{ Bonaire } & po & andere functie & 21 & $11 \%$ \\
\hline & & leraar & 43 & $22 \%$ \\
\hline & $\mathrm{vo} / \mathrm{mbo}$ & andere functie & 18 & $9 \%$ \\
\hline & & leraar & 71 & $36 \%$ \\
\hline \multirow[t]{4}{*}{ Saba } & po & andere functie & 3 & $2 \%$ \\
\hline & & leraar & 11 & $6 \%$ \\
\hline & $\mathrm{vo} / \mathrm{mbo}$ & andere functie & 1 & $1 \%$ \\
\hline & & leraar & 13 & $7 \%$ \\
\hline \multirow[t]{4}{*}{ Sint Eustatius } & Po & andere functie & 4 & $2 \%$ \\
\hline & & leraar & 5 & $3 \%$ \\
\hline & $\mathrm{vo} / \mathrm{mbo}$ & andere functie & 3 & $2 \%$ \\
\hline & & leraar & 4 & $2 \%$ \\
\hline Totaal & & & 197 & $100 \%$ \\
\hline
\end{tabular}

Bron: Enquête lerarenmobiliteit Caribisch Nederland, ROA (2016) 
Tabel B.3 - Waar geboren, waar woonachtig op 16-jarige leeftijd, waar lerarenopleiding gevolgd?

\begin{tabular}{|c|c|c|c|c|c|c|}
\hline & \multicolumn{2}{|c|}{ Geboorte(ei)land } & \multicolumn{2}{|c|}{ 16-jarige leeftijd } & \multicolumn{2}{|c|}{ Lerarenopleiding } \\
\hline & Aantal & Percentage & Aantal & Percentage & Aantal & Percentage \\
\hline Europees Nederland & 86 & $44 \%$ & 98 & $51 \%$ & 105 & $56 \%$ \\
\hline Bonaire & 37 & $19 \%$ & 41 & $21 \%$ & 19 & $10 \%$ \\
\hline Saba & 4 & $2 \%$ & 3 & $2 \%$ & 0 & $0 \%$ \\
\hline Sint Eustatius & 5 & $3 \%$ & 5 & $3 \%$ & 1 & $1 \%$ \\
\hline Curaçao & 24 & $12 \%$ & 19 & $10 \%$ & 24 & $13 \%$ \\
\hline Suriname & 16 & $8 \%$ & 13 & $7 \%$ & 9 & $5 \%$ \\
\hline Ergens anders & 23 & $12 \%$ & 14 & $7 \%$ & 15 & $8 \%$ \\
\hline Niet van toepassing & & & & $0 \%$ & 14 & $7 \%$ \\
\hline Totaal & 195 & $100 \%$ & 193 & $100 \%$ & 187 & $100 \%$ \\
\hline
\end{tabular}

Bron: Enquête lerarenmobiliteit Caribisch Nederland, ROA (2016)

Tabel B.4 - Wat is uw leeftijd?

\begin{tabular}{lcc}
\hline & Aantal & Percentage \\
\hline jonger dan 30 jaar & 35 & $19 \%$ \\
30 t/m 39 jaar & 53 & $29 \%$ \\
40 t/m 49 jaar & 48 & $26 \%$ \\
50 jaar of ouder & 48 & $26 \%$ \\
\hline Totaal & $\mathbf{1 8 4}$ & $\mathbf{1 0 0 \%}$ \\
\hline Bron: Enquête lerarenmobiliteit Caribisch Nederland, ROA (2016)
\end{tabular}

Tabel B.5 - Wat is uw geslacht?

\begin{tabular}{lcc}
\hline & Aantal & Percentage \\
\hline man & 43 & $23 \%$ \\
vrouw & 142 & $77 \%$ \\
\hline Totaal & $\mathbf{1 8 5}$ & $\mathbf{1 0 0 \%}$ \\
\hline Bron: Enquête lerarenmobiliteit Caribisch Nederland, ROA (2016)
\end{tabular}

Tabel B.6 - Heeft u thuiswonende kinderen, meerdere antwoorden mogelijk $(\mathrm{n}=184)$

\begin{tabular}{llcc}
\hline & & Aantal & Percentage \\
\hline Ja, in de leeftijd: & tot 3 jaar oud & 19 & $10 \%$ \\
& 4 tot 11 jaar oud & 43 & $23 \%$ \\
& 12 tot 16 jaar oud & 33 & $18 \%$ \\
& 17 jaar of ouder & 23 & $13 \%$ \\
\hline Nee & & 91 & $49 \%$ \\
\hline Bron: Enquête lerarenmobiliteit Caribisch Nederland ROA (2016)
\end{tabular}


Tabel B.7 - Aantal jaar werkzaam...

\begin{tabular}{lcc:cc|cc}
\hline & \multicolumn{2}{c|}{ In huidige functie } & \multicolumn{2}{c|}{ In onderwijs } & \multicolumn{2}{c}{ Op eiland nu woonachtig } \\
& Aantal & Percentage & Aantal & Percentage & Aantal & Percentage \\
\hline korter dan 2 jaar & 36 & $19 \%$ & 12 & $6 \%$ & 34 & $18 \%$ \\
2 t/m 4 jaar & 62 & $33 \%$ & 22 & $12 \%$ & 60 & $32 \%$ \\
5 t/m 9 jaar & 40 & $21 \%$ & 42 & $22 \%$ & 38 & $20 \%$ \\
10 t/m 19 jaar & 42 & $22 \%$ & 77 & $41 \%$ & 32 & $17 \%$ \\
20 jaar of langer & 8 & $4 \%$ & 36 & $19 \%$ & 23 & $12 \%$ \\
\hline Totaal & $\mathbf{1 8 8}$ & $\mathbf{1 0 0 \%}$ & $\mathbf{1 8 9}$ & $\mathbf{1 0 0} \%$ & $\mathbf{1 8 7}$ & $\mathbf{1 0 0 \%}$ \\
\hline Bron: Enquête lerarenmobiliteit Caribisch Nederland, ROA (2016)
\end{tabular}

Tabel B.8 - Welke talen beheerst $u$, meerdere antwoorden mogelijk $(n=185)$

\begin{tabular}{lcc}
\hline & Aantal & Percentage \\
\hline Nederlands & 173 & $94 \%$ \\
Papiamento & 118 & $64 \%$ \\
Engels & 175 & $95 \%$ \\
Spaans & 78 & $42 \%$ \\
Andere taal & 26 & $14 \%$ \\
\hline
\end{tabular}

Bron: Enquête lerarenmobiliteit Caribisch Nederland, ROA (2016)

Tabel B.9 - Wat is uw moedertaal?

\begin{tabular}{lcc}
\hline & Aantal & Percentage \\
\hline Nederlands & 101 & $56 \%$ \\
Papiamento & 54 & $30 \%$ \\
Engels & 21 & $12 \%$ \\
Spaans & 2 & $1 \%$ \\
Andere taal & 2 & $1 \%$ \\
\hline Totaal & $\mathbf{1 8 0}$ & $\mathbf{1 0 0 \%}$
\end{tabular}

Tabel B.10 - In welke sector werkte u in uw vorige baan?

\begin{tabular}{lcc}
\hline & Aantal & Percentage \\
\hline In het onderwijs & 116 & $63 \%$ \\
In een niet-commerciële sector buiten het onderwijs & 21 & $11 \%$ \\
In een commerciële sector & 19 & $10 \%$ \\
Niet van toepassing, hiervoor studeerde ik & 29 & $16 \%$ \\
\hline Totaal & $\mathbf{1 8 5}$ & $\mathbf{1 0 0 \%}$ \\
\hline Bron: Enquête lerarenmobiliteit Caribisch Nederland, ROA (2016) &
\end{tabular}


Tabel B.11 - Indien hiervoor werkzaam: waar werkte u in uw vorige baan?

\begin{tabular}{lcc}
\hline & Aantal & Percentage \\
\hline Europees Nederland & 80 & $52 \%$ \\
Bonaire & 27 & $17 \%$ \\
Saba & 2 & $1 \%$ \\
Sint Eustatius & 2 & $1 \%$ \\
Curaçao & 17 & $11 \%$ \\
Suriname & 8 & $5 \%$ \\
Ergens anders & 19 & $12 \%$ \\
\hline Totaal & $\mathbf{1 5 5}$ & $\mathbf{1 0 0} \%$ \\
\hline Bron: Enquête lerarenmobiliteit Caribisch Nederland, ROA (2016)
\end{tabular}

Tabel B.12 - In wat voor dienstverband werkt u momenteel?

\begin{tabular}{lcc}
\hline & Aantal & Percentage \\
\hline Vast dienstband & 103 & $56 \%$ \\
Tijdelijk dienstverband met uitzicht op vast & 58 & $31 \%$ \\
Tijdelijk dienstverband (minimaal half jaar) & 15 & $8 \%$ \\
Oproep / invalkracht & 0 & $0 \%$ \\
Als zelfstandige & 1 & $1 \%$ \\
Anders & 8 & $4 \%$ \\
\hline Totaal & $\mathbf{1 8 5}$ & $\mathbf{1 0 0 \%}$ \\
\hline Bron: Enquête lerarenmobiliteit Caribisch Nederland, ROA (2016)
\end{tabular}

Tabel B.13 - Hebt u een voltijd of deeltijd aanstelling?

\begin{tabular}{lcc}
\hline & Aantal & Percentage \\
\hline Voltijd aanstelling & 174 & $94 \%$ \\
Deeltijd aanstelling & 11 & $6 \%$ \\
\hline Totaal & $\mathbf{1 8 5}$ & $\mathbf{1 0 0 \%}$ \\
\hline Bron: Enquête lerarenmobiliteit Caribisch Nederland, ROA (2016)
\end{tabular}

Tabel B.14 - Woont u op dit moment samen met een partner?

\begin{tabular}{lcc}
\hline & Aantal & Percentage \\
\hline Ja & 111 & $60 \%$ \\
Nee & 74 & $40 \%$ \\
\hline Totaal & $\mathbf{1 8 5}$ & $\mathbf{1 0 0 \%}$ \\
\hline Bron: Enquête lerarenmobiliteit Caribisch Nederland, ROA (2016)
\end{tabular}


Tabel B.15 - Wilt $u$ aangeven in welke loonschaal $u$ momenteel bent aangesteld?

\begin{tabular}{lcc}
\hline & Aantal & Percentage \\
\hline LA / schaal 9 & 38 & $24 \%$ \\
LB / schaal 10 & 58 & $36 \%$ \\
LC / schaal 11 & 40 & $25 \%$ \\
LD / schaal 12 & 10 & $6 \%$ \\
LE / schaal 13 & 3 & $2 \%$ \\
Anders, namelijk & 11 & $7 \%$ \\
\hline Totaal & $\mathbf{1 6 0}$ & $\mathbf{1 0 0} \%$ \\
\hline Bron: Enquête lerarenmobiliteit Caribisch Nederland, ROA (2016)
\end{tabular}

Tabel B.16 - Wat was voor u de belangrijkste reden om naar het eiland te komen waar u nu werkt?

\begin{tabular}{lcc}
\hline & Aantal & Percentage \\
\hline Ik ben verhuisd om hier te gaan werken & 128 & $65 \%$ \\
Ik ben verhuisd om hier te gaan studeren & 2 & $1 \%$ \\
Ik ben meeverhuisd met mijn partner en/of familie & 18 & $9 \%$ \\
Ik ben teruggekeerd naar het eiland waar ik ben geboren/opgegroeid & 16 & $8 \%$ \\
Niet van toepassing, ik heb hier altijd al gewoond & 24 & $12 \%$ \\
Anders & 8 & $4 \%$ \\
\hline Totaal & $\mathbf{1 9 6}$ & $\mathbf{1 0 0 \%}$ \\
\hline Bron: Enquête lerarenmobiliteit Caribisch Nederland, ROA (2016) & &
\end{tabular}

Tabel B.17 - Belangrijkste redenen om naar Caribisch Nederland te komen om te werken, meerdere antwoorden mogelijk

\begin{tabular}{lcc} 
& Aantal & Percentage \\
\hline Ik kon in mijn woonomgeving geen baan in het onderwijs vinden & 23 & $18 \%$ \\
Het salaris is hier beter & 9 & $7 \%$ \\
Ik houd van avontuur & 27 & $22 \%$ \\
Ik houd van zon, zee en strand & 11 & $9 \%$ \\
Het Caribische leven trok mij aan & 28 & $22 \%$ \\
Ik wilde eens wat anders in mijn leven & 43 & $34 \%$ \\
Ik werd er door een vriend/familielid die hier al werkte/woonde op geattendeerd & 19 & $15 \%$ \\
Ik had het in mijn woonomgeving niet meer naar mijn zin & 14 & $11 \%$ \\
Ik ben teruggekeerd naar het eiland waar ik ben geboren/opgegroeid & 14 & $11 \%$ \\
Anders & 16 & $13 \%$ \\
\hline Totaal & $\mathbf{1 2 5}$ & $\mathbf{1 0 0} \%$ \\
\hline
\end{tabular}

Bron: Enquête lerarenmobiliteit Caribisch Nederland, ROA (2016) 
Tabel B.18 - Op een schaal van 0-10: hoe tevreden bent u over de informatie die u voorafgaand aan uw aankomst heeft gekregen over de...

\begin{tabular}{|c|c|c|c|c|}
\hline & \multicolumn{2}{|c|}{$\begin{array}{l}\text { Leefomstandigheden in Caribisch } \\
\qquad \text { Nederland }(n=120)\end{array}$} & \multicolumn{2}{|c|}{$\begin{array}{l}\text { Werkomstandigheden in Caribisch } \\
\text { Nederland }(n=121)\end{array}$} \\
\hline & Aantal & Percentage & Aantal & Percentage \\
\hline 0 & 1 & $1 \%$ & 1 & $1 \%$ \\
\hline 1 & 2 & $2 \%$ & 4 & $3 \%$ \\
\hline 2 & 3 & $3 \%$ & 9 & $7 \%$ \\
\hline 3 & 7 & $6 \%$ & 9 & $7 \%$ \\
\hline 4 & 6 & $5 \%$ & 9 & $7 \%$ \\
\hline 5 & 20 & $17 \%$ & 21 & $17 \%$ \\
\hline 6 & 18 & $15 \%$ & 26 & $21 \%$ \\
\hline 7 & 28 & $23 \%$ & 21 & $17 \%$ \\
\hline 8 & 23 & $19 \%$ & 14 & $12 \%$ \\
\hline 9 & 6 & $5 \%$ & 6 & $5 \%$ \\
\hline 10 & 6 & $5 \%$ & 1 & $1 \%$ \\
\hline Totaal & 120 & $100 \%$ & 121 & $100 \%$ \\
\hline
\end{tabular}

Tabel B.19 - Terugkijkend, had u meer informatie over de leef- en werkomstandigheden willen ontvangen?

\begin{tabular}{lcc|cc} 
& $\begin{array}{c}\text { Ja, over leefomstandigheden } \\
(\boldsymbol{n = 1 2 4 )}\end{array}$ & \multicolumn{2}{c}{$\begin{array}{c}\text { Ja, over werkomstandigheden } \\
\text { (n=124) }\end{array}$} \\
& Aantal & Percentage & Aantal & Percentage \\
\hline Nee & 72 & $58 \%$ & 60 & $48 \%$ \\
$\mathrm{Ja}$ & 52 & $42 \%$ & 64 & $52 \%$ \\
\hline Totaal & $\mathbf{1 2 4}$ & $\mathbf{1 0 0 \%}$ & $\mathbf{1 2 4}$ & $\mathbf{1 0 0 \%}$ \\
\hline Bron: Enquête lerarenmobiliteit Caribisch Nederland, ROA (2016) &
\end{tabular}

Tabel B.20 - Hoe lang denkt u nog...

\begin{tabular}{|c|c|c|c|c|c|c|}
\hline & \multicolumn{2}{|c|}{$\begin{array}{c}\text { te werken in uw } \\
\text { huidige functie } \\
\quad(n=163)\end{array}$} & \multicolumn{2}{|c|}{ les te geven $(n=150)$} & \multicolumn{2}{|c|}{$\begin{array}{c}\text { te werken in } \\
\text { Caribisch Nederland } \\
(n=151)\end{array}$} \\
\hline & Aantal & Percentage & Aantal & Percentage & Aantal & Percentage \\
\hline Minder dan 2 jaar & 47 & $29 \%$ & 17 & $11 \%$ & 24 & $16 \%$ \\
\hline 2 tot 5 jaar & 42 & $26 \%$ & 25 & $17 \%$ & 30 & $20 \%$ \\
\hline 5 tot 10 jaar & 22 & $13 \%$ & 30 & $20 \%$ & 17 & $11 \%$ \\
\hline Meer dan 10 jaar & 6 & $4 \%$ & 23 & $15 \%$ & 18 & $12 \%$ \\
\hline Tot mijn pensioen & 46 & $28 \%$ & 55 & $37 \%$ & 62 & $41 \%$ \\
\hline Totaal & 163 & $100 \%$ & 150 & $100 \%$ & 151 & $100 \%$ \\
\hline
\end{tabular}


Tabel B.21 - Op een schaal van 0-10 (met 0 'zeer onwaarschijnlijk' en 10 'zeer waarschijnlijk') hoe waarschijnlijk zijn de volgende scenario's over vijf jaar...

\begin{tabular}{lccccc}
\hline & Aantal & Min. & Max. & Gem. & Std. dev. \\
\hline - Ik geef les op mijn huidige school & 154 & 0 & 10 & 5,6 & 3,2 \\
- Ik geef les op een andere school in Caribisch & 136 & 0 & 10 & 3,4 & 2,9 \\
Nederland & 131 & 0 & 10 & 3,4 & 3,2 \\
- Ik geef les op een school in Nederland (Europa) & 111 & 0 & 10 & 3,0 & 2,9 \\
- Ik geef les op een school, maar niet in Caribisch & 111,9 & 3,4 \\
Nederland en ook niet in Nederland (Europa) & 118 & 0 & 10 & 4,3 & 3 (2016) \\
- Ik geef geen les meer & & & &
\end{tabular}

Tabel B.22 - Op een schaal van 0-10 (met 0 'helemaal niet tevreden' en 10 'helemaal tevreden'): hoe tevreden bent u over uw...

\begin{tabular}{|c|c|c|c|c|}
\hline & \multicolumn{2}{|c|}{ baan $(n=187)$} & \multicolumn{2}{|c|}{ leven in zijn geheel $(n=189)$} \\
\hline & Aantal & Percentage & Aantal & Percentage \\
\hline 0 & 3 & $2 \%$ & 0 & $0 \%$ \\
\hline 1 & 4 & $2 \%$ & 0 & $0 \%$ \\
\hline 2 & 4 & $2 \%$ & 1 & $1 \%$ \\
\hline 3 & 10 & $5 \%$ & 0 & $0 \%$ \\
\hline 4 & 4 & $2 \%$ & 0 & $0 \%$ \\
\hline 5 & 16 & $9 \%$ & 8 & $4 \%$ \\
\hline 6 & 27 & $14 \%$ & 11 & $6 \%$ \\
\hline 7 & 41 & $22 \%$ & 23 & $12 \%$ \\
\hline 8 & 44 & $24 \%$ & 66 & $35 \%$ \\
\hline 9 & 24 & $13 \%$ & 46 & $24 \%$ \\
\hline 10 & 10 & $5 \%$ & 34 & $18 \%$ \\
\hline Totaal & 187 & $100 \%$ & 189 & $100 \%$ \\
\hline
\end{tabular}


Tabel B.23 - Redenen om in huidige baan te blijven, meerdere antwoorden mogelijk $(n=189)$

\begin{tabular}{|c|c|c|}
\hline & Aantal & Perc. \\
\hline \multicolumn{3}{|l|}{ Arbeidsvoorwaarden en -omstandigheden } \\
\hline Het salaris is goed & 61 & $32 \%$ \\
\hline Ik heb een vast dienstverband & 78 & $41 \%$ \\
\hline De arbeidsvoorwaarden (anders dan salaris en dienstverband) zijn goed & 31 & $16 \%$ \\
\hline Er is aandacht voor professionalisering van leraren & 49 & $26 \%$ \\
\hline Er zijn goede mogelijkheden voor opleiding en training & 34 & $18 \%$ \\
\hline Ik wil de lerarenopleiding die ik nu volg afmaken & 18 & $10 \%$ \\
\hline Mijn collega's zijn competent & 27 & $14 \%$ \\
\hline Er zijn voldoende faciliteiten op mijn school (materialen, internet etc) & 36 & $19 \%$ \\
\hline Ik waardeer het personeelsbeleid op mijn school & 14 & $7 \%$ \\
\hline Ik heb goede carrièreperspectieven & 23 & $12 \%$ \\
\hline Mijn werk is uitdagend & 105 & $56 \%$ \\
\hline De samenwerking met collega's is plezierig & 76 & $40 \%$ \\
\hline Er is veel collegiale intervisie en ondersteuning & 17 & $9 \%$ \\
\hline De werksfeer is plezierig & 48 & $25 \%$ \\
\hline Ik waardeer het pedagogisch-didactische klimaat & 37 & $20 \%$ \\
\hline Ik heb een goede band met de leerlingen & 133 & $70 \%$ \\
\hline Ik heb een goede band met de ouders van leerlingen & 77 & $41 \%$ \\
\hline Leraren hebben een positief imago op het eiland & 25 & $13 \%$ \\
\hline \multicolumn{3}{|l|}{ Leefomstandigheden } \\
\hline Ik vind het leven op het eiland prettig & 148 & $78 \%$ \\
\hline Door hier te werken, kan ik uiteindelijk de Nederlandse nationaliteit verkrijgen & 1 & $1 \%$ \\
\hline De onderwijsmogelijkheden / onderwijskwaliteit voor mijn kinderen zijn goed & 12 & $6 \%$ \\
\hline De medische voorzieningen zijn goed & 34 & $18 \%$ \\
\hline De recreatiemogelijkheden zijn goed (winkels, sport, vrije tijd etc.) & 25 & $13 \%$ \\
\hline De kosten voor levensonderhoud zijn laag & 6 & $3 \%$ \\
\hline Er is weinig criminaliteit & 64 & $34 \%$ \\
\hline De sociale controle op het eiland biedt bescherming & 39 & $21 \%$ \\
\hline \multicolumn{3}{|l|}{ Sociaal netwerk } \\
\hline Mijn partner heeft hier werk & 59 & $31 \%$ \\
\hline Mijn partner wil hier blijven & 32 & $17 \%$ \\
\hline Mijn kind(eren) wil(len) hier blijven & 19 & $10 \%$ \\
\hline Mijn partner en/of familie komt hier vandaan & 44 & $23 \%$ \\
\hline Ik heb hier sociale contacten (vrienden, kennissen) & 78 & $41 \%$ \\
\hline Ik voel me verbonden met het eiland & 97 & $51 \%$ \\
\hline \multicolumn{3}{|l|}{ Andere redenen } \\
\hline Andere nog niet genoemde reden \#1 & 30 & $16 \%$ \\
\hline Andere nog niet genoemde reden \#2 & 9 & $5 \%$ \\
\hline \multicolumn{3}{|l|}{ Geen redenen } \\
\hline Er zijn geen redenen waarom ik in mijn huidige baan zou blijven & 10 & $5 \%$ \\
\hline
\end{tabular}


Tabel B.24 - Welke van de genoemde redenen om in uw huidige baan te blijven, is voor $\mathrm{u}$ het belangrijkst?

\begin{tabular}{|c|c|c|}
\hline & Aantal & Perc. \\
\hline \multicolumn{3}{|l|}{ Arbeidsvoorwaarden en -omstandigheden } \\
\hline Het salaris is goed & 4 & $2 \%$ \\
\hline Ik heb een vast dienstverband & 14 & $7 \%$ \\
\hline De arbeidsvoorwaarden (anders dan salaris en dienstverband) zijn goed & 2 & $1 \%$ \\
\hline Er is aandacht voor professionalisering van leraren & 10 & $5 \%$ \\
\hline Er zijn goede mogelijkheden voor opleiding en training & 1 & $1 \%$ \\
\hline Ik wil de lerarenopleiding die ik nu volg afmaken & 6 & $3 \%$ \\
\hline Mijn collega's zijn competent & 0 & $0 \%$ \\
\hline Er zijn voldoende faciliteiten op mijn school (materialen, internet etc) & 1 & $1 \%$ \\
\hline Ik waardeer het personeelsbeleid op mijn school & 0 & $0 \%$ \\
\hline Ik heb goede carrièreperspectieven & 2 & $1 \%$ \\
\hline Mijn werk is uitdagend & 35 & $19 \%$ \\
\hline De samenwerking met collega's is plezierig & 3 & $2 \%$ \\
\hline Er is veel collegiale intervisie en ondersteuning & 0 & $0 \%$ \\
\hline De werksfeer is plezierig & 4 & $2 \%$ \\
\hline Ik waardeer het pedagogisch-didactische klimaat & 0 & $0 \%$ \\
\hline Ik heb een goede band met de leerlingen & 24 & $13 \%$ \\
\hline Ik heb een goede band met de ouders van leerlingen & 2 & $1 \%$ \\
\hline Leraren hebben een positief imago op het eiland & 0 & $0 \%$ \\
\hline \multicolumn{3}{|l|}{ Leefomstandigheden } \\
\hline Ik vind het leven op het eiland prettig & 24 & $13 \%$ \\
\hline Door hier te werken, kan ik uiteindelijk de Nederlandse nationaliteit verkrijgen & 0 & $0 \%$ \\
\hline De onderwijsmogelijkheden / onderwijskwaliteit voor mijn kinderen zijn goed & 1 & $1 \%$ \\
\hline De medische voorzieningen zijn goed & 0 & $0 \%$ \\
\hline De recreatiemogelijkheden zijn goed (winkels, sport, vrije tijd etc.) & 0 & $0 \%$ \\
\hline De kosten voor levensonderhoud zijn laag & 0 & $0 \%$ \\
\hline Er is weinig criminaliteit & 3 & $2 \%$ \\
\hline De sociale controle op het eiland biedt bescherming & 1 & $1 \%$ \\
\hline \multicolumn{3}{|l|}{ Sociaal netwerk } \\
\hline Mijn partner heeft hier werk & 4 & $2 \%$ \\
\hline Mijn partner wil hier blijven & 2 & $1 \%$ \\
\hline Mijn kind(eren) wil(len) hier blijven & 1 & $1 \%$ \\
\hline Mijn partner en/of familie komt hier vandaan & 4 & $2 \%$ \\
\hline Ik heb hier sociale contacten (vrienden, kennissen) & 3 & $2 \%$ \\
\hline Ik voel me verbonden met het eiland & 12 & $6 \%$ \\
\hline \multicolumn{3}{|l|}{ Andere redenen } \\
\hline Andere nog niet genoemde reden \#1 & 13 & $7 \%$ \\
\hline Andere nog niet genoemde reden \#2 & 1 & $1 \%$ \\
\hline \multicolumn{3}{|l|}{ Geen redenen } \\
\hline Er zijn geen redenen waarom ik in mijn huidige baan zou blijven & 10 & $5 \%$ \\
\hline Totaal & 187 & $100 \%$ \\
\hline
\end{tabular}


Tabel B.25 - Redenen om huidige baan te verlaten, meerdere antwoorden mogelijk $(n=186)$

\begin{tabular}{|c|c|c|}
\hline & Aantal & Perc. \\
\hline \multicolumn{3}{|l|}{ Arbeidsvoorwaarden en -omstandigheden } \\
\hline Het salaris is onvoldoende & 43 & $23 \%$ \\
\hline Mijn huidige contract loopt binnenkort af & 13 & $7 \%$ \\
\hline De arbeidsvoorwaarden (anders dan salaris en dienstverband) zijn onvoldoende & 26 & $14 \%$ \\
\hline De werklast / werkdruk is (te) hoog & 69 & $37 \%$ \\
\hline Er is nauwelijks sprake van professionalisering van leraren & 39 & $21 \%$ \\
\hline Er zijn onvoldoende mogelijkheden voor opleiding en training & 38 & $20 \%$ \\
\hline Mijn collega's zijn onvoldoende competent & 29 & $16 \%$ \\
\hline Er zijn onvoldoende faciliteiten op mijn school (materialen, internet etc.) & 35 & $19 \%$ \\
\hline Ik ben het niet eens met het personeelsbeleid op mijn school & 37 & $20 \%$ \\
\hline De carrièreperspectieven zijn beperkt & 32 & $17 \%$ \\
\hline Het werk is onvoldoende uitdagend & 16 & $9 \%$ \\
\hline De samenwerking met collega's is niet plezierig & 21 & $11 \%$ \\
\hline Er is onvoldoende collegiale intervisie en ondersteuning & 25 & $13 \%$ \\
\hline De werksfeer is niet plezierig & 38 & $20 \%$ \\
\hline Ik vind het pedagogisch-didactische klimaat niet goed & 30 & $16 \%$ \\
\hline Ik heb geen goede band met de leerlingen & 3 & $2 \%$ \\
\hline Ik heb geen goede band met de ouders van leerlingen & 2 & $1 \%$ \\
\hline Leraren hebben een negatief imago op het eiland & 9 & $5 \%$ \\
\hline Ik ben op zoek naar een nieuwe uitdaging binnen het onderwijs & 38 & $20 \%$ \\
\hline Ik ben op zoek naar een nieuwe uitdaging buiten het onderwijs & 25 & $13 \%$ \\
\hline \multicolumn{3}{|l|}{ Leefomstandigheden } \\
\hline Ik vind het leven op het eiland onprettig & 11 & $6 \%$ \\
\hline Ik ben uitgekeken op het eiland waar ik werk & 15 & $8 \%$ \\
\hline De onderwijsmogelijkheden / onderwijskwaliteit voor mijn kinderen zijn onvoldoende & 36 & $19 \%$ \\
\hline De medische voorzieningen zijn onvoldoende & 19 & $10 \%$ \\
\hline De recreatiemogelijkheden zijn onvoldoende (winkels, sport, vrije tijd etc.) & 27 & $15 \%$ \\
\hline De kosten van levensonderhoud zijn (te) hoog & 69 & $37 \%$ \\
\hline Er is veel criminaliteit & 10 & $5 \%$ \\
\hline De sociale controle is benauwend & 15 & $8 \%$ \\
\hline \multicolumn{3}{|l|}{ Sociaal netwerk } \\
\hline Mijn partner heeft geen werk / kan hier geen werk vinden & 11 & $6 \%$ \\
\hline Mijn partner wil hier niet langer blijven & 18 & $10 \%$ \\
\hline Mijn kind(eren) wil(len) hier niet langer blijven & 13 & $7 \%$ \\
\hline Ik heb hier weinig sociale contacten (vrienden, kennissen) & 13 & $7 \%$ \\
\hline Ik heb een ziek familielid waar ik voor wil zorgen & 9 & $5 \%$ \\
\hline Ik voel me niet verbonden met het eiland & 8 & $4 \%$ \\
\hline \multicolumn{3}{|l|}{ Andere redenen } \\
\hline Andere nog niet genoemde reden \#1 & 25 & $13 \%$ \\
\hline Andere nog niet genoemde reden \#2 & 12 & $6 \%$ \\
\hline \multicolumn{3}{|l|}{ Geen redenen } \\
\hline Er zijn geen redenen waarom ik mijn huidige baan zou verlaten & 31 & $17 \%$ \\
\hline
\end{tabular}


Tabel B.26 - Welke van de genoemde redenen om uw huidige baan te verlaten, is voor $\mathrm{u}$ het belangrijkst?

\begin{tabular}{|c|c|c|}
\hline & Aantal & Perc. \\
\hline \multicolumn{3}{|l|}{ Arbeidsvoorwaarden en -omstandigheden } \\
\hline Het salaris is onvoldoende & 20 & $11 \%$ \\
\hline Mijn huidige contract loopt binnenkort af & 5 & $3 \%$ \\
\hline De arbeidsvoorwaarden (anders dan salaris en dienstverband) zijn onvoldoende & 4 & $2 \%$ \\
\hline De werklast / werkdruk is (te) hoog & 25 & $14 \%$ \\
\hline Er is nauwelijks sprake van professionalisering van leraren & 0 & $0 \%$ \\
\hline Er zijn onvoldoende mogelijkheden voor opleiding en training & 4 & $2 \%$ \\
\hline Mijn collega's zijn onvoldoende competent & 3 & $2 \%$ \\
\hline Er zijn onvoldoende faciliteiten op mijn school (materialen, internet etc.) & 1 & $1 \%$ \\
\hline Ik ben het niet eens met het personeelsbeleid op mijn school & 2 & $1 \%$ \\
\hline De carrièreperspectieven zijn beperkt & 1 & $1 \%$ \\
\hline Het werk is onvoldoende uitdagend & 1 & $1 \%$ \\
\hline De samenwerking met collega's is niet plezierig & 2 & $1 \%$ \\
\hline Er is onvoldoende collegiale intervisie en ondersteuning & 0 & $0 \%$ \\
\hline De werksfeer is niet plezierig & 7 & $4 \%$ \\
\hline Ik vind het pedagogisch-didactische klimaat niet goed & 9 & $5 \%$ \\
\hline Ik heb geen goede band met de leerlingen & 0 & $0 \%$ \\
\hline Ik heb geen goede band met de ouders van leerlingen & 0 & $0 \%$ \\
\hline Leraren hebben een negatief imago op het eiland & 0 & $0 \%$ \\
\hline Ik ben op zoek naar een nieuwe uitdaging binnen het onderwijs & 8 & $4 \%$ \\
\hline Ik ben op zoek naar een nieuwe uitdaging buiten het onderwijs & 8 & $4 \%$ \\
\hline \multicolumn{3}{|l|}{ Leefomstandigheden } \\
\hline Ik vind het leven op het eiland onprettig & 3 & $2 \%$ \\
\hline Ik ben uitgekeken op het eiland waar ik werk & 2 & $1 \%$ \\
\hline De onderwijsmogelijkheden / onderwijskwaliteit voor mijn kinderen zijn onvoldoende & 8 & $4 \%$ \\
\hline De medische voorzieningen zijn onvoldoende & 0 & $0 \%$ \\
\hline De recreatiemogelijkheden zijn onvoldoende (winkels, sport, vrije tijd etc.) & 2 & $1 \%$ \\
\hline De kosten van levensonderhoud zijn (te) hoog & 5 & $3 \%$ \\
\hline Er is veel criminaliteit & 0 & $0 \%$ \\
\hline De sociale controle is benauwend & 1 & $1 \%$ \\
\hline \multicolumn{3}{|l|}{ Sociaal netwerk } \\
\hline Mijn partner heeft geen werk / kan hier geen werk vinden & 2 & $1 \%$ \\
\hline Mijn partner wil hier niet langer blijven & 5 & $3 \%$ \\
\hline Mijn kind(eren) wil(len) hier niet langer blijven & 4 & $2 \%$ \\
\hline Ik heb hier weinig sociale contacten (vrienden, kennissen) & 1 & $1 \%$ \\
\hline Ik heb een ziek familielid waar ik voor wil zorgen & 3 & $2 \%$ \\
\hline Ik voel me niet verbonden met het eiland & 1 & $1 \%$ \\
\hline \multicolumn{3}{|l|}{ Andere redenen } \\
\hline Andere nog niet genoemde reden \#1 & 15 & $8 \%$ \\
\hline Andere nog niet genoemde reden \#2 & 2 & $1 \%$ \\
\hline \multicolumn{3}{|l|}{ Geen redenen } \\
\hline Er zijn geen redenen waarom ik mijn huidige baan zou verlaten & 31 & $17 \%$ \\
\hline Totaal & 185 & $100 \%$ \\
\hline
\end{tabular}

Bron: Enquête lerarenmobiliteit Caribisch Nederland, ROA (2016) 


\section{Bijlage C: Vragenlijst}

INTRO If you would like to read this in English, please use the button above. Hartelijk dank voor uw interesse in dit onderzoek. U kunt de vragenlijst starten door op de oranje knop '>>' te klikken.

Selectie1 Deze vragenlijst is specifiek bedoeld voor onderwijsgevend personeel op één van de volgende eilanden binnen Caribisch Nederland: Bonaire, Sint Eustatius of Saba. Op welk eiland bent u woonachtig?

O Bonaire (1)

O Sint Eustatius (2)

O Saba (3)

O Geen van deze (4)

If Geen van deze Is Selected, Then Skip To Helaas, deze vragenlijst is niet voor...

Selectie2 Wat is uw functie?

O Leraar (1)

Leraar in opleiding (2)

Onderwijsassistent (3)

O Instructeur (4)

O Anders, namelijk (6)

O Ik geef geen onderwijs (7)

If Ik geef geen onderwijs Is Selected, Then Skip To Helaas, deze vragenlijst is niet voor...

\footnotetext{
Answer If Deze vragenlijst is specifiek bedoeld voor onderwijsgevend personeel dat werkzaam is op \&eacute;\&eacute; $n$ van de volgende eilanden binnen Caribisch Nederland: Bonaire, Sint Eustatius of Saba, ook w... Geen van deze Is Selected Or Wat is uw functie? Ik geef geen onderwijs Is Selected EXIT Helaas, deze vragenlijst is niet voor $u$ bedoeld. Hartelijk dank voor uw deelname! Op het volgende scherm wordt de vragenlijst afgesloten.

If Helaas, deze vragenlijst is... Is Displayed, Then Skip To End of Survey
} 
Q1 In welke onderwijssector bent u werkzaam?Meerdere antwoorden mogelijk

- Primair onderwijs (1)

ㄱoortgezet onderwijs (2)

Middelbaar beroepsonderwijs (3)

Anders, namelijk (4)

INTROQ2 Wilt u aangeven waar u geboren bent, waar u woonde toen u 16 jaar oud was, en waar uw lerarenopleiding hebt gevolgd / volgt?

Q2A1 Geboren:

O Nederland (Europa) (1)

O Bonaire (2)

O Saba (3)

O Sint Eustatius (4)

O Aruba (5)

O Curaçao (6)

Sint Maarten (7)

O Guyana (8)

O Suriname (9)

O Venezuela (10)

O Amerikaanse Maagdeneilanden (11)

O Dominicaanse Republiek (12)

O Jamaica (13)

O Saint Kitts \& Nevis (14)

O Trinidad \& Tobago (15)

O Canada (16)

O Verenigde Staten (17)

O Filippijnen (18)

O Ander land (19) 
Q2B1 16 jaar oud:

O Nederland (Europa) (1)

O Bonaire (2)

O Saba (3)

O Sint Eustatius (4)

O Aruba (5)

O Curaçao (6)

O Sint Maarten (7)

O Guyana (8)

O Suriname (9)

O Venezuela (10)

O Amerikaanse Maagdeneilanden (11)

O Dominicaanse Republiek (12)

O Jamaica (13)

Saint Kitts \& Nevis (14)

O Trinidad \& Tobago (15)

O Canada (16)

O Verenigde Staten (17)

O Filippijnen (18)

Ander land (19)

Q2C1 Lerarenopleiding:(indien niet van toepassing, selecteer 'n.v.t.')

O Nederland (Europa) (1)

Bonaire (2)

O Saba (3)

Sint Eustatius (4)

O Aruba (5)

O Curaçao (6)

O Sint Maarten (7)

O Guyana (8)

O Suriname (9)

O Venezuela (10)

O Amerikaanse Maagdeneilanden (11)

O Dominicaanse Republiek (12)

O Jamaica (13)

O Saint Kitts \& Nevis (14)

O Trinidad \& Tobago (15)

O Canada (16)

O Verenigde Staten (17)

O Filippijnen (18)

Ander land (19)

O n.v.t. (20) 


\section{Answer If Ben ik geboren: Ander land Is Selected}

Q2A2 In welk land bent u geboren?

\section{Answer If Toen ik 16 was:\&nbsp; Ander land Is Selected}

Q2B2 In welk land woonde u toen u 16 jaar was?

\section{Answer If Lerarenopleiding (indien niet van toepassing, selecteer 'n.v.t.'):}

Ander land Is Selected

Q2C2 In welk land hebt u uw lerarenopleiding gevolgd / volgt u uw lerarenopleiding?

Q3 Wat was voor $u$ de belangrijkste reden om naar het eiland te komen waar $u$ nu werkt?

I $\mathrm{k}$ ben verhuisd om hier te gaan werken (1)

O Ik ben verhuisd om hier te gaan studeren (2)

O Ik ben meeverhuisd met mijn partner en/of familie (3)

O Niet van toepassing, ik heb hier altijd al gewoond (4)

O Anders, namelijk (5)

If Ik ben verhuisd om hier te ... Is Not Selected, Then Skip To Hoe lang bent u reeds werkzaam?

Q4 Wat zijn de belangrijkste redenen dat u naar Caribisch Nederland bent gekomen om te werken?Meerdere antwoorden mogelijk

I Ik kon in mijn woonomgeving geen baan in het onderwijs vinden (1)

Het salaris is hier beter (2)

I Ik houd van avontuur (3)

I I houd van zon, zee en strand (4)

- Het Caribische leven trok mij aan (5)

I I wilde eens wat anders in mijn leven (6)

I Ik werd er door een vriend/familielid die hier al werkte/woonde op geattendeerd (7)

I Ik had het in mijn woonomgeving niet meer naar mijn zin (8)

- Anders, namelijk (9)

Q5 Op een schaal van 0 'helemaal niet tevreden' tot 10 'helemaal tevreden', hoe tevreden bent $u$ over de informatie die $u$ voorafgaand aan uw aankomst heeft gekregen over...

de leefomstandigheden op Caribisch Nederland (1)

de werkomstandigheden op Caribisch Nederland (2) 
Q6 Terugkijkend, had u meer informatie over de leef- en werkomstandigheden willen ontvangen? Zo ja, welke informatie?

- Ja, ik had meer informatie gewild over de leefomstandigheden, namelijk (1)

Ja, ik had meer informatie gewild over de werkomstandigheden, namelijk (2)

Nee, geen behoefte (3)

INTROQ7 Hoe lang bent u reeds werkzaam?

Q7A Aantal jaar werkzaam in uw huidige functie

Q7B Aantal jaar werkzaam in het onderwijs

Q7C Aantal jaar werkzaam op het eiland waar u nu woont

Q8 Hoe lang denkt u nog...

\begin{tabular}{|l|c|c|c|c|c|c|} 
& $\begin{array}{c}\text { Minder } \\
\text { dan 2 jaar } \\
(1)\end{array}$ & $\begin{array}{l}2 \text { tot 5 } \\
\text { jaar (2) }\end{array}$ & $\begin{array}{c}5 \text { tot 10 } \\
\text { jaar (3) }\end{array}$ & $\begin{array}{c}\text { Meer } \\
\text { dan 10 } \\
\text { jaar (4) }\end{array}$ & $\begin{array}{c}\text { Tot mijn } \\
\text { pensioen } \\
\text { (5) }\end{array}$ & $\begin{array}{c}\text { Weet } \\
\text { niet (6) }\end{array}$ \\
\hline $\begin{array}{l}\text { te werken } \\
\text { in uw } \\
\text { huidige } \\
\text { functie } \\
\text { (huidige }\end{array}$ & 0 & 0 & 0 & 0 & 0 & 0 \\
$\begin{array}{l}\text { school) (1) } \\
\text { les te } \\
\text { geven (2) }\end{array}$ & 0 & 0 & 0 & 0 & 0 & 0 \\
$\begin{array}{l}\text { te werken } \\
\text { in Caribisch }\end{array}$ & 0 & 0 & 0 & 0 & 0 & 0 \\
$\begin{array}{l}\text { Nederland } \\
\text { (7) }\end{array}$ & 0 & & & \\
\hline
\end{tabular}


Q9 Als $u$ een inschatting maakt van uw persoonlijke situatie over vijf jaar, hoe waarschijnlijk zijn dan de volgende scenario's? Antwoord (voor ieder scenario) op een schaal van 0 'zeer onwaarschijnlijk' tot 10 'zeer waarschijnlijk'.

Ik geef les op mijn huidige school (1)

Ik geef les op een andere school in Caribisch Nederland (2)

Ik geef les op een school in Nederland (Europa) (3)

Ik geef les op een school, maar niet in Caribisch Nederland en ook niet in

Nederland (Europa) (4)

Ik geef geen les meer (5)

Q10 Op de volgende vragen verzoeken we $u$ te antwoorden op een schaal van 0 'helemaal niet tevreden' tot 10 'helemaal tevreden'.

Hoe tevreden bent u met uw baan? (1)

Hoe tevreden bent u met uw leven in zijn geheel? (2) 
Q11 Mensen kunnen verschillende redenen hebben waarom ze hun in hun huidige baan blijven, bijvoorbeeld vanwege goede arbeidsvoorwaarden of leefomstandigheden. Wat zijn voor $u$ de belangrijkste redenen waarom $u$ in uw huidige baan wilt blijven? Meerdere antwoorden mogelijk

- Het salaris is goed (1)

I Ik heb een vast dienstverband (2)

- De arbeidsvoorwaarden (anders dan salaris en dienstverband) zijn goed (3)

- Er is aandacht voor professionalisering van leraren (4)

Er zijn goede mogelijkheden voor opleiding en training (5)

I Ik wil de lerarenopleiding die ik nu volg afmaken (6)

- Mijn collega's zijn competent (7)

- Er zijn voldoende faciliteiten op mijn school (materialen, internet etc). (8)

I Ik waardeer het personeelsbeleid op mijn school (9)

I Ik heb goede carrièreperspectieven (10)

- Mijn werk is uitdagend (11)

- De samenwerking met collega's is plezierig (12)

- Er is veel collegiale intervisie en ondersteuning (13)

- De werksfeer is plezierig (14)

- Ik waardeer het pedagogisch-didactische klimaat (15)

- Ik heb een goede band met de leerlingen (16)

I Ik heb een goede band met de ouders van leerlingen (17)

- Leraren hebben een positief imago op het eiland (18)

- Ik vind het leven op het eiland prettig (19)

- Door hier te werken, kan ik uiteindelijk de Nederlandse nationaliteit verkrijgen (20)

D De onderwijsmogelijkheden / onderwijskwaliteit voor mijn kinderen zijn goed (21)

- De medische voorzieningen zijn goed (22)

口 De recreatiemogelijkheden zijn goed (winkels, sport, vrije tijd etc.) (23)

- De kosten voor levensonderhoud zijn laag (24)

Er is weinig criminaliteit (25)

- De sociale controle op het eiland biedt bescherming (26)

- Mijn partner heeft hier werk (27)

- Mijn partner wil hier blijven (28)

口 Mijn kind(eren) wil(len) hier blijven (29)

- Mijn partner en/of familie komt hier vandaan (30)

I Ik heb hier sociale contacten (vrienden, kennissen) (31)

- Ik voel me verbonden met het eiland (32)

- Andere nog niet genoemde reden \#1, namelijk: (33)

- Andere nog niet genoemde reden \#2, namelijk: (34)

- Er zijn geen redenen waarom ik in mijn huidige baan zou blijven (35)

If Mensen kunnen verschi... Is Equal to 1, Then Skip To Naast redenen om in de huidige baan $t$...

Q12 Welke van de genoemde redenen om in uw huidige baan te blijven is voor $u$ het belangrijkst? 
Q13 Naast redenen om in de huidige baan te blijven, kunnen mensen ook verschillende redenen hebben waarom ze hun baan willen verlaten. Wat zijn voor $u$ belangrijke redenen waarom u uw huidige baan wilt verlaten? Meerdere antwoorden mogelijk

Het salaris is onvoldoende (1)

- Mijn huidige contract loopt binnenkort af (2)

- De arbeidsvoorwaarden (anders dan salaris en dienstverband) zijn onvoldoende (3)

De werklast / werkdruk is (te) hoog (4)

- Er is nauwelijks sprake van professionalisering van leraren (5)

- Er zijn onvoldoende mogelijkheden voor opleiding en training (6)

- Mijn collega's zijn onvoldoende competent (7)

- Er zijn onvoldoende faciliteiten op mijn school (materialen, internet etc.) (8)

- Ik ben het niet eens met het personeelsbeleid op mijn school (9)

De carrièreperspectieven zijn beperkt (10)

- Het werk is onvoldoende uitdagend (11)

D De samenwerking met collega's is niet plezierig (12)

- Er is onvoldoende collegiale intervisie en ondersteuning (13)

口 De werksfeer is niet plezierig (14)

I I vind het pedagogisch-didactische klimaat niet goed (15)

I Ik heb geen goede band met de leerlingen (16)

- Ik heb geen goede band met de ouders van leerlingen (17)

- Leraren hebben een negatief imago op het eiland (18)

- Ik ben op zoek naar een nieuwe uitdaging binnen het onderwijs (19)

- Ik ben op zoek naar een nieuwe uitdaging buiten het onderwijs (20)

I I vind het leven op het eiland onprettig (21)

- Ik ben uitgekeken op het eiland waar ik werk (22)

口 De onderwijsmogelijkheden / onderwijskwaliteit voor mijn kinderen zijn onvoldoende (23)

- De medische voorzieningen zijn onvoldoende (24)

- De recreatiemogelijkheden zijn onvoldoende (winkels, sport, vrije tijd etc.) (25)

De kosten van levensonderhoud zijn (te) hoog (26)

- Er is veel criminaliteit (27)

De sociale controle is benauwend (28)

Mijn partner heeft geen werk / kan hier geen werk vinden (29)

Mijn partner wil hier niet langer blijven (30)

- Mijn kind(eren) wil(len) hier niet langer blijven (31)

- Ik heb hier weinig sociale contacten (vrienden, kennissen) (32)

- Ik heb een ziek familielid waar ik voor wil zorgen (33)

- Ik voel me niet verbonden met het eiland (34)

- Andere nog niet genoemde reden \#1, namelijk: (35)

- Andere nog niet genoemde reden \#2, namelijk: (36)

- Er zijn geen redenen waarom ik mijn huidige baan zou verlaten (38)

If Naast redenen om in de huid... Is Equal to 1, Then Skip To End of Block

Q14 Welke van de genoemde redenen om uw huidige baan te verlaten, is voor $u$ het belangrijkst? 
Q15 Hebt u ideeën of tips over hoe het aantrekkelijker gemaakt kan worden om de huidige leraren te behouden voor Caribisch Nederland?

O Ja, namelijk (1)

O Nee (2)

Q16 Hebt $u$ ideeën of tips over hoe het voor leraren aantrekkelijker gemaakt kan worden om in Caribisch Nederland te komen werken? We hebben het dus over de werving van nieuwe leraren.

O Ja, namelijk (1)

O Nee (2)

INTROSLOT Tot slot stellen we u graag wat korte vragen stellen over uw persoonlijke situatie en uw baankenmerken. Deze gegevens helpen ons om de resultaten beter te kunnen duiden en geven bovendien inzicht in de opbouw van de populatie leraren in Caribisch Nederland.

Q17 Wat is uw leeftijd?

Q18 Wat is uw geslacht

O Man (1)

Orouw (2)

Q19 Welke talen beheerst u? Meerdere antwoorden mogelijk

a Nederlands (1)

- Papiamento (2)

- Engels (3)

口 Spaans (4)

Anders, namelijk (5)

\section{Answer If Welke talen beheerst u? Meerdere antwoorden mogelijk}

q://QID16/SelectedChoicesCount Is Greater Than 1

Q20 Wat is uw moedertaal?

Q21 In welke sector werkte $u$ in uw vorige baan?

In het onderwijs (1)

In een niet-commerciële sector buiten het onderwijs (bijvoorbeeld overheid, zorg) (2)

In een commerciële sector (3)

O Niet van toepassing, hiervoor studeerde ik (4) 


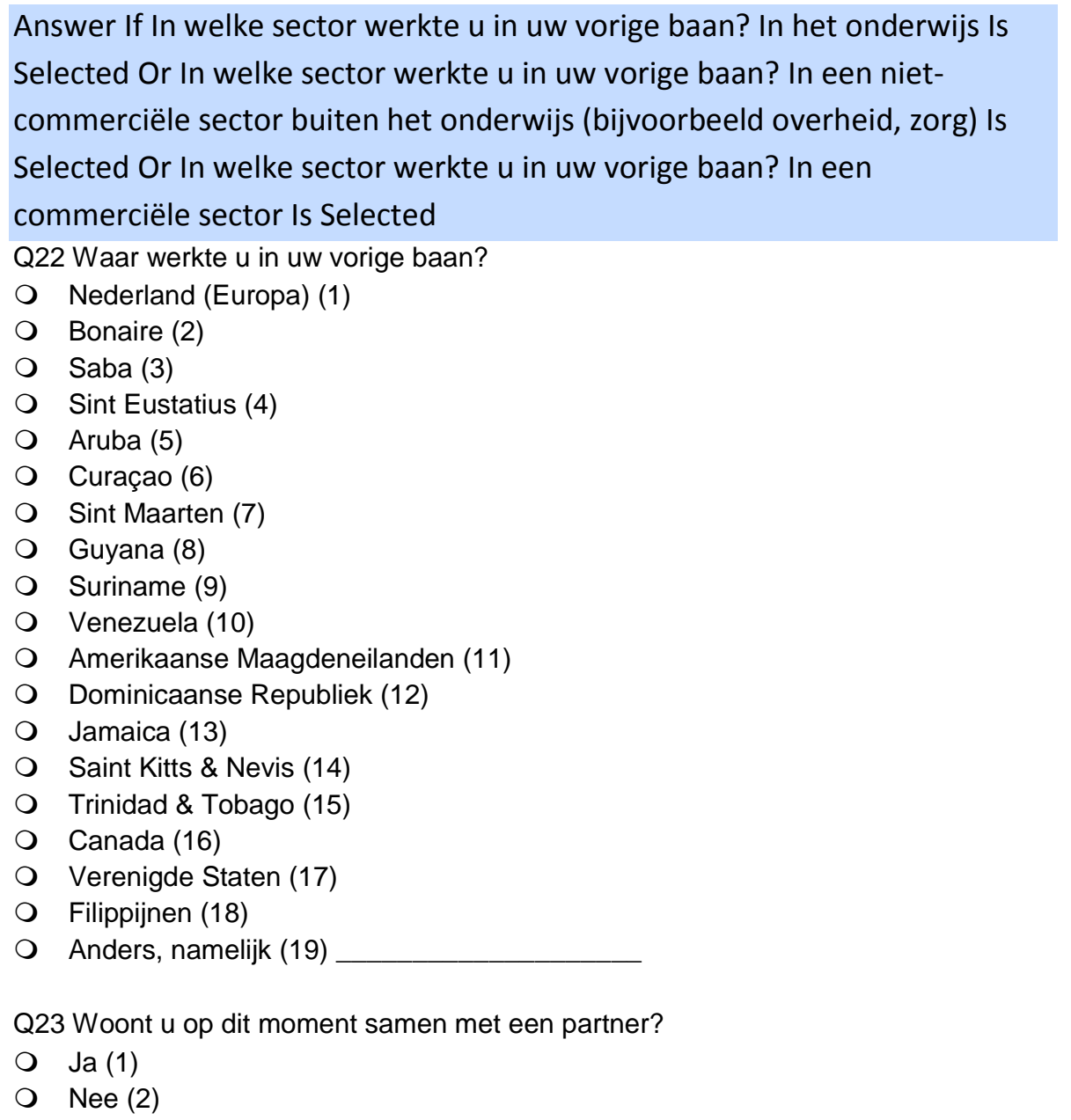

Q24 Hebt u thuiswonende kinderen? Meerdere antwoorden mogelijk

- Ja, tot 3 jaar oud (1)

- Ja, 4 tot 11 jaar oud (2)

a Ja, 12 tot 16 jaar oud (3)

Ja, 17 jaar of ouder (4)

․ Nee (5)

Q25 In wat voor dienstverband werkt u momenteel?

O Vast dienstband (1)

Tijdelijk dienstverband met uitzicht op vast (2)

O Tijdelijk dienstverband (minimaal half jaar) (3)

O Oproep / invalkracht (4)

O Als zelfstandige (5)

Anders, namelijk (6) 
Q26 Hebt u een voltijd of deeltijd aanstelling?

O Voltijd aanstelling (1)

○ Deeltijd aanstelling (2)

Q27 Wilt $u$ aangeven in welke loonschaal u momenteel bent aangesteld?

O LA / schaal 9 (1)

O LB / schaal 10 (2)

O LC / schaal 11 (3)

O LD / schaal 12 (4)

O LE / schaal 13 (5)

Anders, namelijk (6)

Q28 Heeft u nog opmerkingen over het onderzoek of over deze vragenlijst? O Ja, namelijk (1)

Nee (2) 


\section{Bijlage D: Lijst van geïnterviewden}

De interviews en gesprekken hebben plaatsgevonden van 3 tot 12 april 2016 tijdens het werkbezoek van Frank Cörvers aan vertegenwoordigers van alle scholen in Caribisch Nederland. Ter voorbereiding daarvan zijn er, in de periode januari tot april 2016 via Skype diverse personen geïnterviewd door Suzan Becks (Maestro Kompas) en Frank Cörvers (ROA). Daarnaast hebben er enkele gesprekken plaatsgevonden tussen Frank Cörvers en medewerkers van het CAOP en het ministerie van Onderwijs, Cultuur en Wetenschap in Den Haag. Voorts hebben Frank Cörvers en Suzan Becks vertegenwoordigers van de UniCarib partners gesproken tijdens een bijeenkomst in Utrecht.

\begin{tabular}{|c|c|}
\hline (Ei)land en organisatie & Naam (functie) \\
\hline \multicolumn{2}{|l|}{ Europees Nederland } \\
\hline CAOP & $\begin{array}{l}\text { Nadir James } \\
\text { (fondsmanager/secretaris) }\end{array}$ \\
\hline $\begin{array}{l}\text { Ministerie van Onderwijs, Cultuur en } \\
\text { Wetenschap (OCW) }\end{array}$ & $\begin{array}{l}\text { Justus de Hoge } \\
\text { (programmamanager); Aldrik in } \\
\text { 't Hout (programmamanager) }\end{array}$ \\
\hline Open Universiteit Heerlen & Pleuni Corton (masterstudente) \\
\hline \multicolumn{2}{|l|}{ Bonaire } \\
\hline Basisschool de Pelikaan & $\begin{array}{l}\text { Harriet Peeters (leraar); Lars } \\
\text { van Ravenhorst (schoolleider) }\end{array}$ \\
\hline Fundashon FORMA & $\begin{array}{l}\text { Inge Berben (directeur); Tanja } \\
\text { Staring Pijnenburg (mentor } \\
\text { arbeidstoeleiding) }\end{array}$ \\
\hline Maestro Kompas & $\begin{array}{l}\text { Haydee Grandisson } \\
\text { (docentcoach } \\
\text { Scholengemeenschap Bonaire, } \\
\text { SGB); Geert van der Plas } \\
\text { (docentcoach } \\
\text { Scholengemeenschap Bonaire, } \\
\text { SGB) }\end{array}$ \\
\hline $\begin{array}{l}\text { Rijksdienst Caribisch Nederland } \\
\text { (RCN) }\end{array}$ & $\begin{array}{l}\text { Maritsa Silberie } \\
\text { (beleidsmedewerker) }\end{array}$ \\
\hline $\begin{array}{l}\text { Scholengemeenschap Bonaire } \\
\text { (SGB) }\end{array}$ & $\begin{array}{l}\text { Lilianne Hercules (directeur } \\
\text { onderwijs); Frans van Efferink } \\
\text { (algemeen directeur); drie } \\
\text { leraren, één instructeur }\end{array}$ \\
\hline $\begin{array}{l}\text { Stichting R.K. Schoolbestuur Bonaire } \\
\text { (RKSB-Bon) }\end{array}$ & $\begin{array}{l}\text { Nilva Wout (directeur- } \\
\text { bestuurder) }\end{array}$ \\
\hline $\begin{array}{l}\text { Stichting Openbaar onderwijs } \\
\text { Bonaire (OOB) }\end{array}$ & $\begin{array}{l}\text { Eveliene Coenen (algemeen } \\
\text { directeur); vijf leraren }\end{array}$ \\
\hline
\end{tabular}




\begin{tabular}{|l|l|}
\hline Sint Eustatius & $\begin{array}{l}\text { Ernie Simmons (bestuurder); } \\
\text { Ellis Woodley (schoolleider) }\end{array}$ \\
\hline $\begin{array}{l}\text { Expertise Center Education care } \\
\text { (EOZ) }\end{array}$ & Camelia Berkel (directeur) \\
\hline Golden Rock School & Irene Ortega (schoolleider) \\
\hline Governor de Graaff School & Evert Meijer (schoolleider) \\
\hline Gwendoline van Puttenschool & $\begin{array}{l}\text { Hans Odijk (staffunctionaris); } \\
\text { zeven leraren }\end{array}$ \\
\hline $\begin{array}{l}\text { Lynch Plantation SDA Primary } \\
\text { School }\end{array}$ & $\begin{array}{l}\text { LaVerne David-Duggings } \\
\text { (schoolleider); lerarenstaf }\end{array}$ \\
\hline Maestro Kompas & $\begin{array}{l}\text { Mariëtte Zuidgeest } \\
\text { (docentcoach Gwendoline van } \\
\text { Puttenschool) }\end{array}$ \\
\hline Saba & $\begin{array}{l}\text { Mariëtte Zuidgeest } \\
\text { (docentcoach Saba } \\
\text { Comprehensive School) }\end{array}$ \\
\hline Maestro Kompas & $\begin{array}{l}\text { Anton Hermans (schoolleider); } \\
\text { vijf leraren }\end{array}$ \\
\hline Saba Comprehensive School & $\begin{array}{l}\text { Jarmila Berkel-Wilson (adjunct- } \\
\text { schoolleider en IB'er); Diane } \\
\text { Wilson (schoolleider); twee } \\
\text { leraren }\end{array}$ \\
\hline Sacred Heart Primary School & \\
\hline Overig & Wim Didderen \\
\hline Maestro Kompas & Diverse personen \\
\hline UniCarib partners (UoC, UA, IPA) & \\
\hline & \\
\hline
\end{tabular}

